NISTIR 7644

\title{
Quick Capture Platform Use \\ Cases \\ User Interaction Specifications
}

\author{
Brian Stanton \\ Yee-Yin Choong \\ Mary Theofanos
}

National Institute of Standards and Technology • U.S. Department of Commerce 
NISTIR 7644

\title{
Quick Capture Platform Use Cases User Interaction Specifications
}

\author{
Brian Stanton \\ Yee-Yin Choong \\ Mary Theofanos \\ Information Access Division \\ Information Technology Laboratory \\ National Institute of Standards and Technology \\ Gaithersburg, MD 20899
}

September 04, 2009

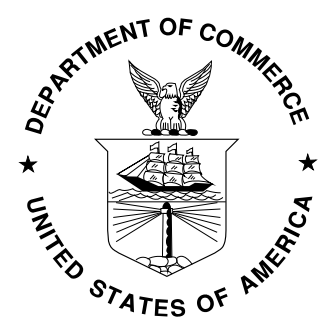

U.S. Department of Commerce Gary Locke, Secretary

National Institute of Standards and Technology Patrick D. Gallagher, Deputy Director 


\section{$\underline{\text { Table of Contents }}$}

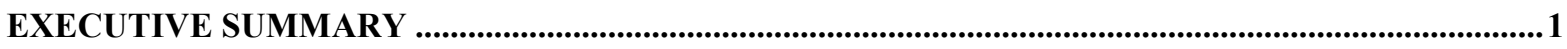

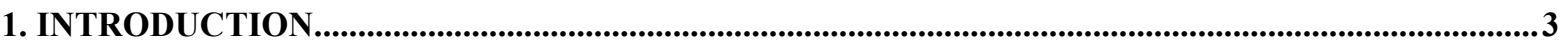

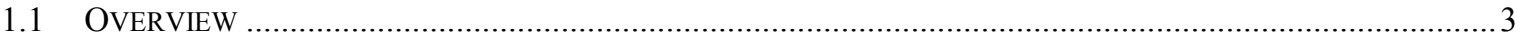

1.2 SCOPE

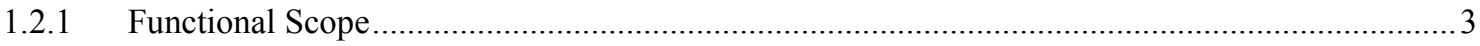

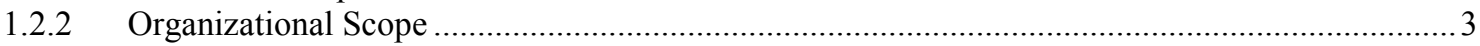

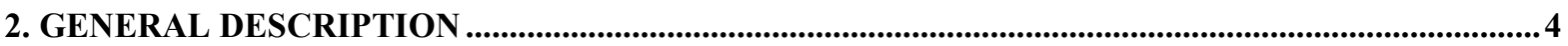

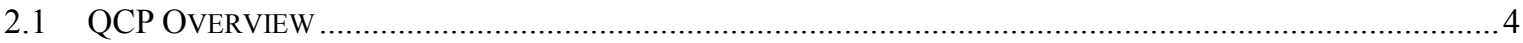

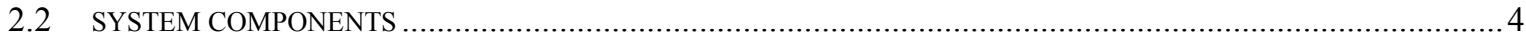

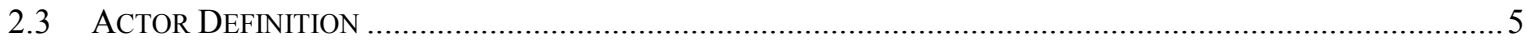

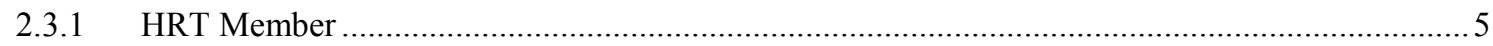

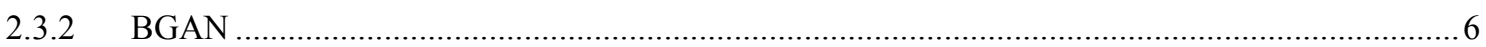

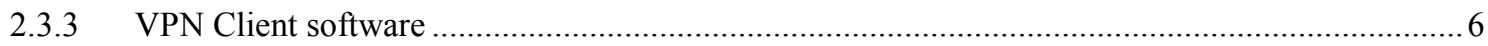

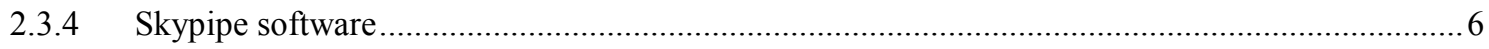

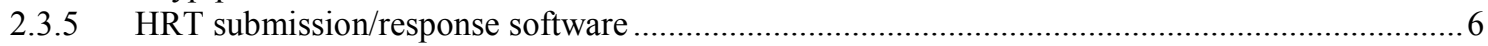

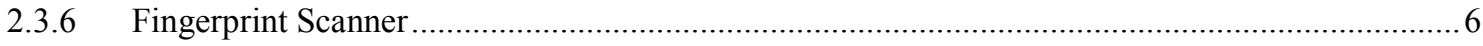

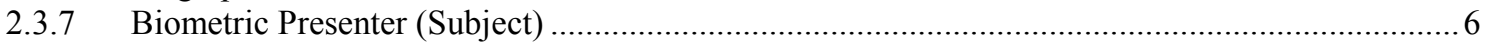

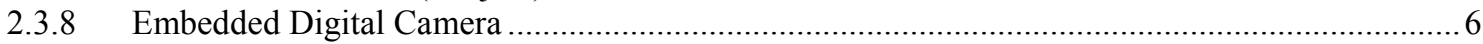

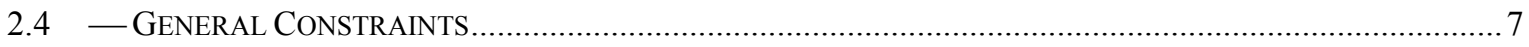

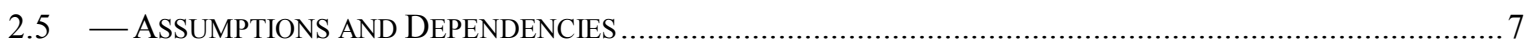

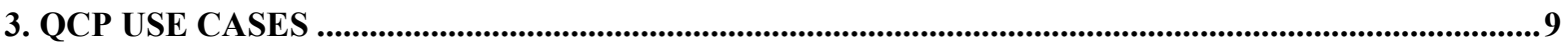

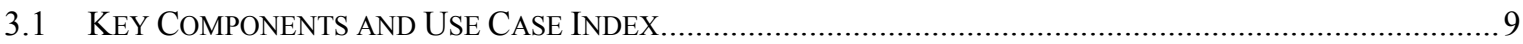

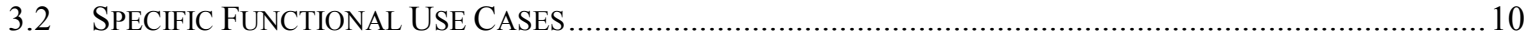

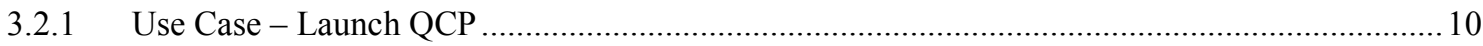

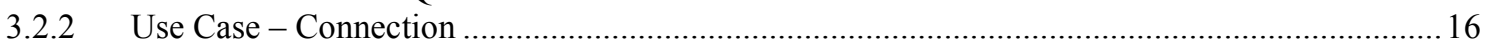

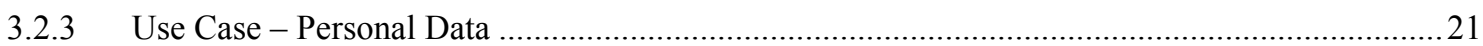

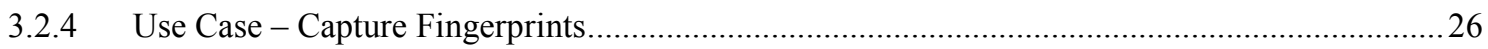

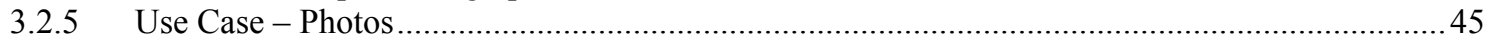

3.2.6 Use Case - Transaction History and Submissions ...................................................................56

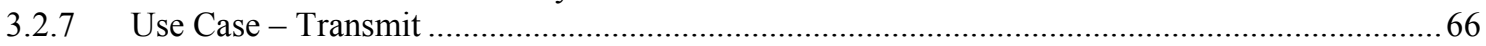

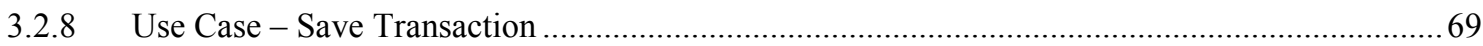

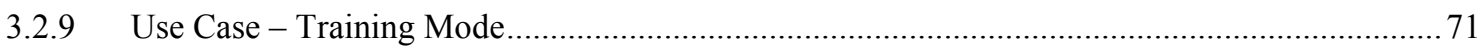

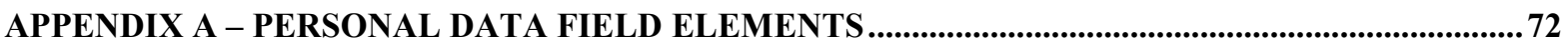

APPENDIX B - ATTRIBUTES IN TRANSACTION HISTORY AND SUBMISSIONS.............................73

APPENDIX C - SEARCH CRITERIA IN TRANSACTION HISTORY AND SUBMISSIONS................76

APPENDIX D - FEATURES AVAILABILITY AND ASSOCIATED FUNCTIONAL AREAS................77 


\section{$\underline{\text { List of Figures }}$}

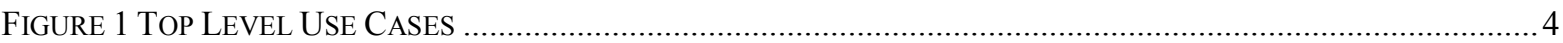

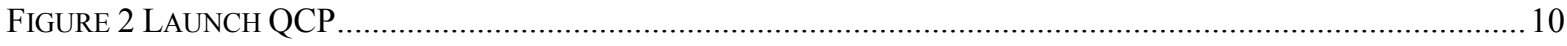

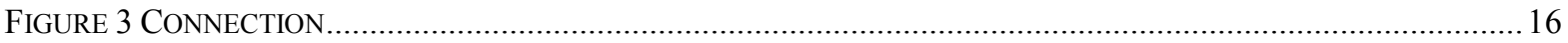

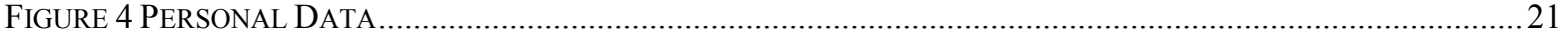

FIGURE 5 CAPTURE FINGERPRINTS (SlaP, ROLlS, DiSPLAY, AND ANNOTATION) .......................................26

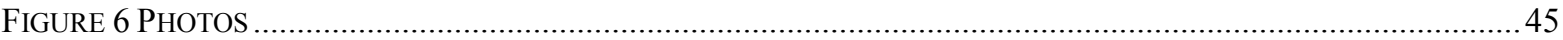

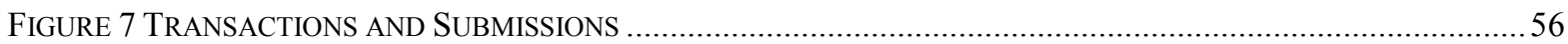

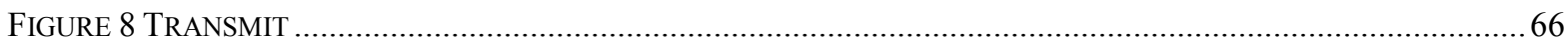

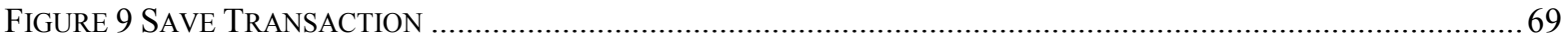




\section{EXECUTIVE SUMMARY}

The Federal Bureau of Investigation's (FBI) Hostage Rescue Team (HRT) and other Department of Defense operations require mobile biometric collection (Mobile ID) devices. These devices are used worldwide, often in hostile environments to identify terrorists and other potential threats to our national security. The HRT members often operate under very dangerous circumstances, any time day or night, and under any weather conditions. These operational settings require a device that is easy to transport and is usable (effective and efficient) under a wide range of conditions. Today's solutions are non-optimal. They have been retrofitted from existing COTS products, resulting in equipment that is very heavy and unwieldy to be carried in and out of operations in a backpack. In addition, there is no standardization to the user interface. Thus in a high stress and time critical operation, the user of the device cannot depend on consistency or ease of use of the user interface. Not only is the device physically heavy and unwieldy but this lack of standardization and consistency demands a high cognitive load when using the device which can compromise the user's safety.

The FBI has recognized the need for a smaller footprint device, referred to as Quick Capture Platform (QCP), and one that provides consistency and a streamlined workflow for the users in the field. However, the FBI has been unable to identify any commercial vendor willing to develop a set of requirements that will adequately address the human factors and usability needs of their organization. Simply reusing the existing application in a different form factor was not an acceptable solution.

NIST's Visualization and Usability Group has partnered with the FBI HRT to provide a set of requirements enabling the FBI to build a portable biometric collection device capable of transmitting biometrics to a central database and receiving identity information with a consistent and usable user interface.

The goal of the project was to define a set of user requirements with a high fidelity user interface demonstration for a small platform, e.g. screen the size of an index card, that minimizes the cognitive load by:

- Defining an entirely new interaction paradigm

- Increasing the consistency among interaction patterns

- Streamlining and flattening the workflow and

- Reducing the visual noise;

To achieve this goal, the NIST team employed a rigorous user-centered design (UCD) process. The process included the following activities: 
- User requirements and Task analysis - operational data was collected over an eight hour time period by observing user tasks in realistic setting, interviews, demonstrations and brain storming sessions. User and task analysis is the process of learning about users by observing them in action. It is different from asking them questions in focus groups outside the user's typical environments and away from their work. Often times, users cannot articulate what they do, especially if they are very familiar with the tasks they perform. Only by observing users and probing for more understanding in the context of their work can you obtain the information that will encourage new design constructs. The current operational process flow was documented based on the results of task analysis. User requirements were analyzed and organized into functional areas.

- Workflow improvement - a new workflow was developed based on user needs and observed efficiencies.

- Use cases development - a set of use cases was developed that describe (step by step) the new system functionality from a user's point of view. There are 29 individual use cases for this application. The use case document defines the functional requirements and user interaction specifications for the new system.

- Wireframes development - Wireframes are screen designs depicting functions and workflow as specified in the use cases. Wireframes do not include the look and feel, e.g. color, fonts, or graphics, of the user interface.

- High fidelity user interface development - demonstration to offer a more exact example of the user interface and determine the viability of the design on the small interface.

This document only describes the functional requirements and user interaction specifications, in the format of use cases, of all the functional requirements gathered, for the Mobile ID quick capture platform (QCP). 


\section{INTRODUCTION}

\section{1 - OVERVIEW}

The document defines functional requirements for the Quick Capture Platform (QCP). These requirements have been developed for a portable hardware device with small screen size, such as $5 "(\mathrm{~W}) \times 3 "(\mathrm{H})$.

Functional requirements are the definitions of specific features or services in which the system must provide a response. Section 3 of this document contains complete definitions, in the format of use cases, of all the functional requirements gathered.

\section{2 - SCOPE}

\subsection{1 - Functional Scope}

This document describes only the functionality and the human interaction of a user interface (UI) for the QCP application. Functions and features that are in support of the UI and how the QCP application processes the data depicted by the UI will be assumed, but not described in the document.

\subsection{2 - Organizational Scope}

This section addresses the organizations that QCP must interact with in order to successfully identify, gather, and confirm functional and non-functional requirements.

- FBI HRT provides the strategic direction and requirements.

- NIST Biometrics Usability team provides use cases and wireframes for designing a usable user interface according to usability industry standards. 


\section{GENERAL DESCRIPTION}

\section{$2.1-$ QCP OVERVIEW}

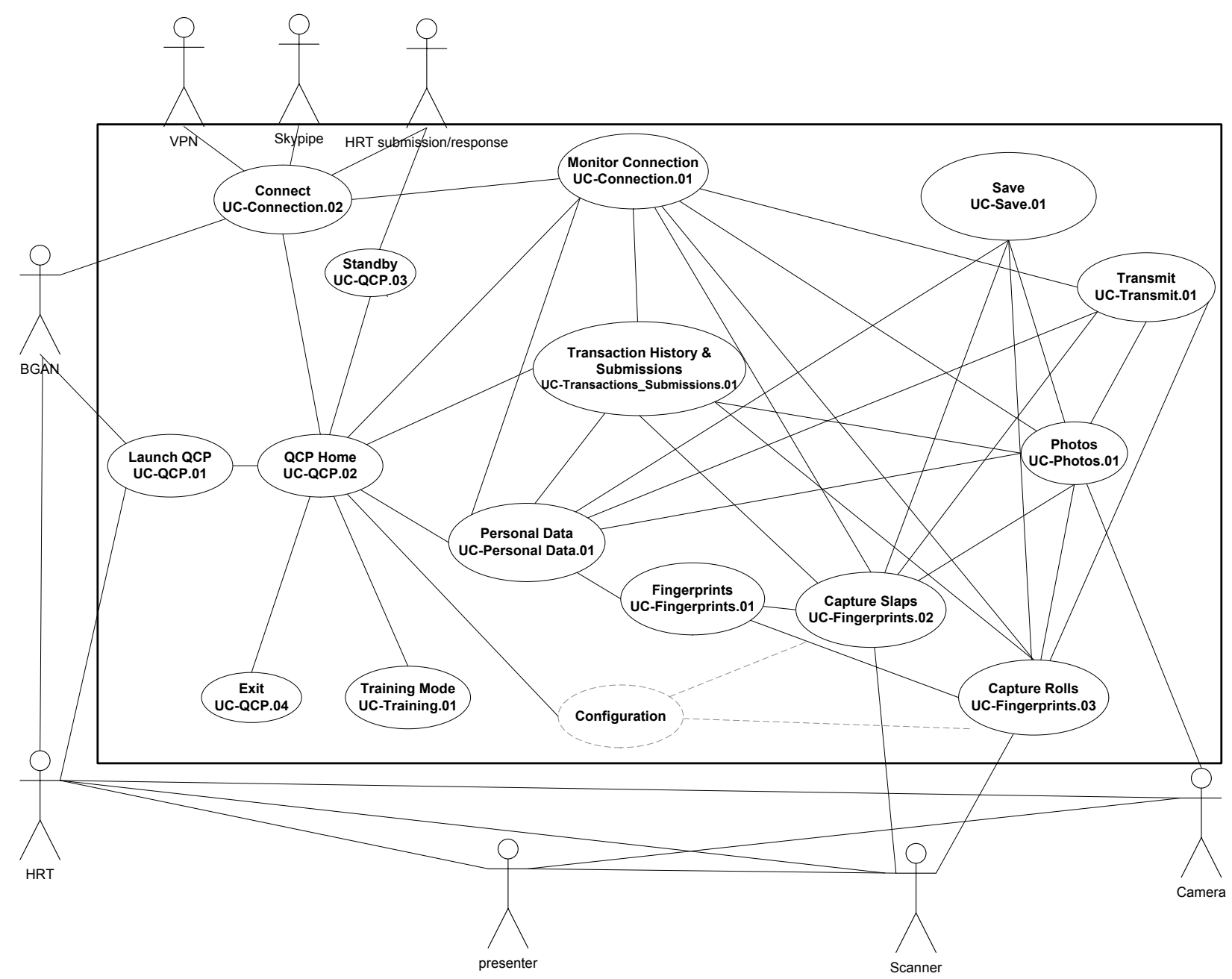

Figure 1 Top Level Use Cases

\section{2 - SYSTEM COMPONENTS}

The key functional components that will comprise QCP include:

- QCP Application

- Network connection/monitoring 
- Create Slaps Transaction

- Personal Data

$\circ$ Fingerprints

o Photos

- Create Query Transaction

- Personal Data

○ Fingerprints

- Photos

- Create Rolls Transaction

- Personal Data

$\circ$ Fingerprints

o Photos

- Transaction History and Submissions

- Training

- QCP Standby

\section{3-ACTOR DEFINITION}

An actor (characterized as a stick figure drawing) is a user/component that plays a role with respect to the system. It is someone or something outside the application that interacts with QCP. The actors defined in this section will be referenced throughout this document, specifically in Section 3 where use cases are modeled/documented as a part of the application's functional requirements. The defined actors and their definitions are specified below.

- HRT member

- Communication device, i.e. BGAN

- VPN client software

- Acceleration software, i.e. Skypipe software

- Submission software, i.e. HRT submission/response software

- Fingerprint scanner

- Biometric presenter (Subject)

- Embedded digital camera

\subsection{1 - HRT Member}

Performs the following tasks:

- User of the QCP application

- Interaction with other actors:

- BGAN

- VPN client software 
- Skypipe software

○ HRT Submission/Response software

O Fingerprint scanner

○ Biometric presenter (Subject)

- Embedded digital camera

\subsection{2 - BGAN}

Performs the following tasks:

- Transmits and receives data via uplink

\subsection{3 - VPN Client software}

Performs the following tasks:

- Requests Username and Password for authentication

- Passes information between Skypipe software and BGAN

\subsection{4 - Skypipe software}

Performs the following tasks:

- Communicates between VPN client software and HRT submission/response software

\subsection{5 - HRT submission/response software}

Performs the following tasks:

- Polls for incoming responses

- Submits data to Skypipe software for subsequent uplinks

\subsection{6 - Fingerprint Scanner}

Performs the following tasks:

- Acquires fingerprints images from presenter for QCP application

\subsection{7 - Biometric Presenter (Subject)}

Performs the following tasks:

- Provides biometrics, e.g. fingerprints, face, and iris

\subsection{8 — Embedded Digital Camera}

Performs the following tasks: 
- Acquires photographs of presenter for QCP application

\section{4 - GENERAL CONSTRAINTS}

\section{Constraints:}

- QCP application's control of any digital cameras is only for cameras physically integral to the QCP hardware platform

\section{5 - ASSUMPTIONS AND DEPENDENCIES}

The following section presents the assumptions and dependencies for the QCP application. Assumptions include items that if changed would affect the specific use cases in Section 3 or items that if changed might impede or divert the direction of development. Dependencies define resources or activities that the project relies upon for successful completion. The QCP assumptions and dependencies include:

\section{Assumptions:}

- If communication devices other than BGAN are used, such as cell phones or WiFi, the use cases will need to be modified to reflect the statuses of the devices and the protocols used.

- If biometric devices other than fingerprint scanner or digital camera are used, such as an iris scanner, the use cases will need to be modified to reflect the statuses of those biometric devices.

- There will be a cancel option for:

- Fingerprint capture process

- Annotation

$\circ$ Exit QCP application with unsaved data

- Leaving a transaction with unsaved data

- There will be a method to configure:

$\circ$ Fingerprint capture sequence

- Default VPN user name and password

- Default location on the computer to save RAP sheets automatically

- Help option shall always be accessible.

- The features such as Open, Save, and Print, etc. will be available in some areas in the QCP application, refer to Appendix $D$ for a listing of the features and their availability in different functional areas.

Dependencies:

- BGAN is working properly with QCP application, i.e. when BGAN is active, the following information will be communicated from BGAN to QCP application: 
○ Signal Strength, e.g. decibel reading

- Connectivity sensing, e.g. cable and network

- BGAN statuses

- VPN Client software, Skypipe software, HRT Submission/Response software are integrated with QCP application for:

- Data transfer

- Statuses

- QCP application shall be configurable for successful communications with a fingerprint scanner and an embedded digital camera. 


\section{QCP USE CASES}

\section{1 - KEY COMPONENTS AND USE CASE INDEX}

The following section outlines the requirements expressed by stakeholders/subject matter experts (SMEs) associated with QCP. These requirements are stated in the format of use cases. The use cases revolve around the major key component areas documented in Section 2.2. Table 1 provides a listing of use cases so that they can be easily found.

Table 1 Index of Fully Specified Use cases

\begin{tabular}{|c|c|c|c|}
\hline Version & Use Case ID & Use Case Name & Page \# \\
\hline 1.0 & UC - QCP.01 & Launch QCP & 11 \\
\hline 1.0 & UC - QCP.02 & QCP Home & 11 \\
\hline 1.0 & UC - QCP.03 & QCP Standby & 13 \\
\hline 1.0 & UC - QCP.04 & Exit QCP & 14 \\
\hline 1.0 & UC - Connection. 01 & Monitor Connection & 16 \\
\hline 1.0 & UC - Connection. 02 & Connect & 19 \\
\hline 1.0 & UC - Personal Data.01 & Personal Data & 21 \\
\hline 1.0 & UC - Fingerprints. 01 & Fingerprints & 26 \\
\hline 1.0 & UC - Fingerprints. 02 & Capture Slaps & 27 \\
\hline 1.0 & UC - Fingerprints. 03 & Capture Rolls & 30 \\
\hline 1.0 & UC - Fingerprints.04 & Display Fingerprints & 34 \\
\hline 1.0 & UC - Fingerprints. 05 & Display Individual Prints & 38 \\
\hline 1.0 & UC - Fingerprints. 06 & Annotate Prints - User Initiated & 40 \\
\hline 1.0 & UC - Fingerprints. 07 & Annotate Prints - QCP Application Initiated & 42 \\
\hline 1.0 & UC - Fingerprints. 08 & Modify/Remove Annotation & 43 \\
\hline 1.0 & UC - Photos.01 & Photos & 45 \\
\hline 1.0 & UC - Photos. 02 & $\begin{array}{l}\text { Capture Photos with an Embedded Digital } \\
\text { Camera }\end{array}$ & 47 \\
\hline 1.0 & UC - Photos. 03 & Import Photos & 48 \\
\hline 1.0 & UC - Photos.04 & Display Photos & 49 \\
\hline 1.0 & UC - Photos.05 & Display Individual Photos & 51 \\
\hline 1.0 & UC - Photos.06 & Delete Photos & 54 \\
\hline 1.0 & $\begin{array}{l}\text { UC }- \\
\text { Transactions_Submissions.01 }\end{array}$ & Display Transaction History and Submissions & 56 \\
\hline 1.0 & UC - Transaction. 01 & View Transaction Responses & 60 \\
\hline 1.0 & UC - Transaction. 02 & Access Transaction Details & 61 \\
\hline 1.0 & UC - Transaction. 03 & Update Transaction & 62 \\
\hline
\end{tabular}




\begin{tabular}{|l|l|l|l|}
\hline 1.0 & UC - Transaction.04 & View RAP Sheet & 63 \\
\hline 1.0 & UC - Transmit.01 & Transmit & 66 \\
\hline 1.0 & UC - Save.01 & Save Transaction & 69 \\
\hline 1.0 & UC - Training.01 & Training Mode & 71 \\
\hline
\end{tabular}

\section{2 - SPECIFIC FUNCTIONAL USE CASES}

\subsection{1 - Use Case - Launch QCP}

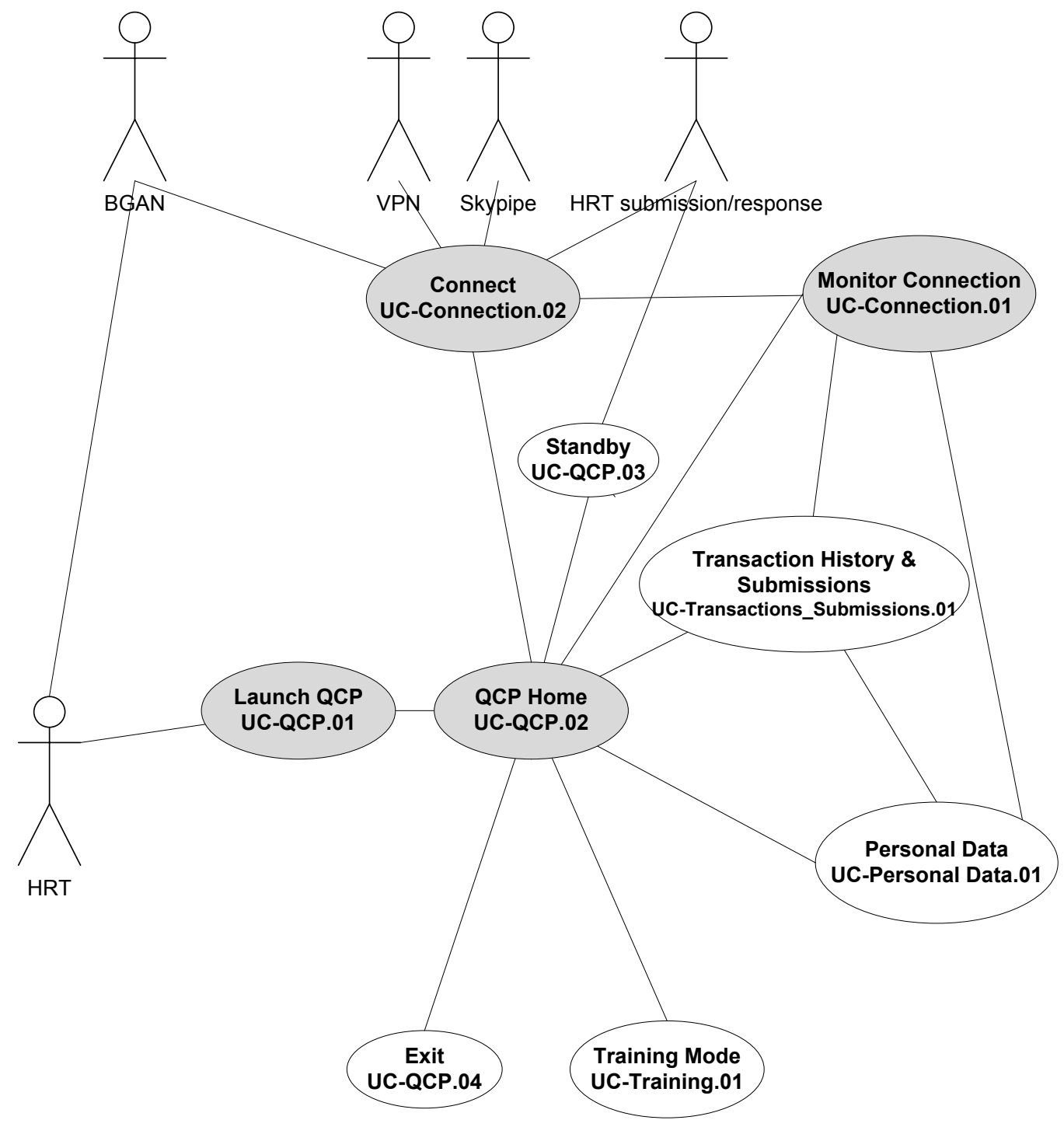

Figure 2 Launch QCP 


\subsubsection{UC - QCP.01 - Launch}

\begin{tabular}{|c|c|}
\hline UC- QCP.01 & Launch QCP \\
\hline Actors & HRT member \\
\hline Precondition & None \\
\hline Postcondition & QCP application successfully launched \\
\hline \\
\hline Extends From & \\
\hline \multicolumn{2}{|l|}{ Super Use Case } \\
\hline Trigger & User decides to start QCP application. \\
\hline \multicolumn{2}{|l|}{ Description } \\
\hline \multicolumn{2}{|c|}{$\begin{array}{l}\text { The user decides to launch QCP application. The application presents connection status and } \\
\text { options to access various functional areas. }\end{array}$} \\
\hline \multicolumn{2}{|c|}{ Process Description } \\
\hline $\begin{array}{l}\text { Primary Process } \\
\text { Scenario }\end{array}$ & Launch QCP Application \\
\hline Step 1 & User decides to launch QCP application. \\
\hline Step 2 & $\begin{array}{l}\text { QCP application presents to the user: } \\
\text { - QCP Home (UC - QCP.02) }\end{array}$ \\
\hline $\begin{array}{l}\text { Exceptions, Error } \\
\text { Situations: }\end{array}$ & $\begin{array}{l}\text { - Error: QCP fails to start } \\
\text { ○ QCP logs error(s) } \\
\circ \text { QCP displays an error message indicating the failure } \\
\text { of launching QCP application } \\
\text { - Error: Scanner not available } \\
\quad \text { QCP displays an error message indicating the scanner } \\
\quad \text { unavailability }\end{array}$ \\
\hline \multicolumn{2}{|l|}{ Open Issues/Notes } \\
\hline
\end{tabular}

\subsubsection{UC - QCP.02 - QCP Home}

\begin{tabular}{|l|l|}
\hline UC- QCP.02 & QCP Home \\
\hline Actors & HRT member \\
\hline Precondition & None \\
\hline Postcondition & QCP home successfully displayed \\
\hline Includes & \\
\hline Extends From & \\
\hline
\end{tabular}




\begin{tabular}{|c|c|}
\hline Super Use Case & QCP.01 \\
\hline Trigger & $\begin{array}{l}\text { - User decides to start QCP application. } \\
\text {-OR- } \\
\text { - User decides to access the QCP Home feature (from use cases } \\
\text { where QCP Home is available) }\end{array}$ \\
\hline \multicolumn{2}{|l|}{ Description } \\
\hline \multicolumn{2}{|c|}{$\begin{array}{l}\text { The application presents QCP home with connection status and options to access various } \\
\text { functional areas. }\end{array}$} \\
\hline \multicolumn{2}{|c|}{ Process Description } \\
\hline $\begin{array}{l}\text { Primary Process } \\
\text { Scenario }\end{array}$ & QCP Home \\
\hline Step 1 & $\begin{array}{l}\text { QCP application presents to the user: } \\
\text { - Connection status (Primary Scenario in } U C-\text { Connection.01) } \\
\text { - Options to } \\
\circ \text { Connect (available conditionally, see Exception) } \\
\circ \text { Create New Slaps Transaction } \\
\circ \text { Create New Rolls Transaction } \\
\circ \text { Create Query Transaction } \\
\circ \text { Access Transaction History and Submissions } \\
\circ \text { Enable or Disable Training Mode } \\
\circ \text { Place QCP Application in or out of Standby mode } \\
\circ \text { Exit QCP Application }\end{array}$ \\
\hline Step 2 & $\begin{array}{l}\text { - UC-Connection.02 if user selects Connect option } \\
\text { - } U C \text { - Personal Data.01 if user selects Create New Slaps } \\
\text { Transaction, Create New Rolls Transaction, or Create Query } \\
\text { Transaction option } \\
\text { - } U C-\text { Transactions_Submissions.01 if user selects access } \\
\text { Transaction History and Submissions option } \\
\text { - } U C-\text { Training.01 if user selects Training Mode option } \\
\text { - } U C-Q C P .03 \text { if user selects Standby option } \\
\text { - } \quad U C-Q C P .04 \text { if user selects Exit QCP Application option }\end{array}$ \\
\hline $\begin{array}{l}\text { Exceptions, Error } \\
\text { Situations: }\end{array}$ & $\begin{array}{l}\text { - Exception: "Connect" feature will not be available, if: } \\
\text { O Connection status is active } \\
- \text { OR- } \\
\quad \text { O Communication hardware is not present } \\
\text { - Exception: if QCP is in Standby mode, user selects any of the } \\
\text { following options will take QCP out of the Standby mode } \\
\text { (alternate scenario in } U C-Q C P .03) \text { : }\end{array}$ \\
\hline
\end{tabular}




\begin{tabular}{|c|c|}
\hline & $\begin{array}{ll} & \text { Connect } \\
\circ & \text { New Slaps Transaction } \\
\circ & \text { New Rolls Transaction } \\
\circ & \text { Query Transaction } \\
\circ & \text { Transaction History and Submissions }\end{array}$ \\
\hline Open Issues/Notes & \\
\hline
\end{tabular}

\subsubsection{UC - QCP.03 - Standby}

\begin{tabular}{|c|c|}
\hline UC- QCP.03 & QCP Standby \\
\hline Actors & HRT member \\
\hline Precondition & QCP application successfully launched. \\
\hline Postcondition & QCP application successfully placed in or out of standby mode. \\
\hline \multicolumn{2}{|l|}{ Includes } \\
\hline \multicolumn{2}{|l|}{ Extends From } \\
\hline Super Use Case & UC - QCP.01 \\
\hline Trigger & User decides to change QCP application's standby mode. \\
\hline \multicolumn{2}{|l|}{ Description } \\
\hline \multicolumn{2}{|c|}{ The user decides to change the standby mode of the QCP application. } \\
\hline \multicolumn{2}{|c|}{ Process Description } \\
\hline $\begin{array}{l}\text { Primary Process } \\
\text { Scenario }\end{array}$ & Place QCP Application in Standby mode \\
\hline Step 1 & $\begin{array}{l}\text { QCP application: } \\
\text { - Pauses the process of HRT Submission/Response software } \\
\text { - Disables the option of changing the Training mode }\end{array}$ \\
\hline Step 2 & $\begin{array}{l}\text { QCP application presents to the user: } \\
\text { - Indication of standby status }\end{array}$ \\
\hline $\begin{array}{l}\text { Exceptions, Error } \\
\text { Situations: }\end{array}$ & $\begin{array}{l}\text { - Exception - if the standby request occurs during a submission or } \\
\text { response communication, the HRT Submission/Response } \\
\text { software should not be paused until the completion of the } \\
\text { communication. }\end{array}$ \\
\hline $\begin{array}{l}\text { Alternate Process } \\
\text { Scenario } 1\end{array}$ & Take QCP Application out of Standby mode \\
\hline
\end{tabular}




\begin{tabular}{|l|l|}
\hline Step 1 & $\begin{array}{l}\text { QCP application: } \\
\bullet \quad \text { Resumes the process of HRT Submission/Response software } \\
\bullet \quad \text { Enables the option of changing the Training mode }\end{array}$ \\
\hline Step 2 & $\begin{array}{l}\text { QCP application presents to the user: } \\
\bullet \quad \text { Indication of standby status }\end{array}$ \\
\hline Step 3 & QCP Home $(U C-Q C P .01)$. \\
\hline Open Issues/Notes & \\
\hline
\end{tabular}

\subsubsection{UC - QCP.04 - Exit}

\begin{tabular}{|c|c|}
\hline UC- QCP.05 & Exit QCP \\
\hline Actors & HRT member \\
\hline Precondition & QCP application successfully launched. \\
\hline Postcondition & QCP application successfully ended. \\
\hline \multicolumn{2}{|l|}{ Includes } \\
\hline \multicolumn{2}{|l|}{ Extends From } \\
\hline Super Use Case & $\mathrm{UC}-\mathrm{QCP} .01$ \\
\hline Trigger & $\begin{array}{l}\text { User decides to end QCP application: } \\
\text { - Select "Exit QCP Application" in } U C-Q C P .01 \\
-\mathrm{OR}- \\
-\quad \text { Click the close window icon "x" in the application window }\end{array}$ \\
\hline \multicolumn{2}{|l|}{ Description } \\
\hline \multicolumn{2}{|c|}{ The user decides to end QCP application. The application shuts down all communications. } \\
\hline \multicolumn{2}{|c|}{ Process Description } \\
\hline $\begin{array}{l}\text { Primary Process } \\
\text { Scenario }\end{array}$ & Exit QCP Application \\
\hline Step 1 & $\begin{array}{l}\text { QCP application presents to the user: } \\
\text { - A request to confirm exit, indicating: } \\
\text { O Consequences of exit } \\
\circ \text { The following processes will be ended: } \\
\text { - Network communication from the BGAN } \\
\text { - VPN connection } \\
\text { - Skypipe processing } \\
\text { - HRT Submission/Response software }\end{array}$ \\
\hline Step 2 & User confirms the exit action. \\
\hline Step 3 & $\begin{array}{l}\text { QCP application: } \\
-\quad \text { Stops the followings: }\end{array}$ \\
\hline
\end{tabular}




\begin{tabular}{|c|c|}
\hline & $\begin{array}{l}\text { O Network communication from the BGAN } \\
\circ \text { VPN connection } \\
\circ \text { Skypipe processing } \\
\circ \text { HRT Submission/Response software } \\
\text { - Resets "Standby" mode to its default status, i.e. out of standby } \\
\text { - Resets "Training" mode to its default status, i.e. out of training } \\
\text { - QCP application terminates. }\end{array}$ \\
\hline $\begin{array}{l}\text { Exceptions, Error } \\
\text { Situations: }\end{array}$ & $\begin{array}{l}\text { - Error - An error message is displayed if QCP application cannot } \\
\text { stop any or all of the followings : } \\
\circ \text { Network communication from the communication } \\
\circ \text { VPN connection } \\
\circ \text { Skypipe processing } \\
\circ \text { HRT Submission/Response software }\end{array}$ \\
\hline $\begin{array}{l}\text { Alternate Process } \\
\text { Scenario } 1\end{array}$ & Exit QCP application via close window icon " $x$ " \\
\hline Step 1 & User clicks the close window icon " $\mathrm{x}$ " in the application window. \\
\hline Step 2 & $\begin{array}{l}\text { QCP application presents to the user: } \\
\text { - A request to confirm exit, indicating: } \\
\text { - Consequences of exit } \\
\text { - The following processes will be ended: } \\
\circ \text { Network communication from the communication } \\
\circ \text { VPN connection } \\
\circ \text { Skypipe processing } \\
\circ \text { HRT Submission/Response software } \\
\end{array}$ \\
\hline Step 3 & Same as steps 2 to 3 in primary scenario. \\
\hline Open Issues/Notes & \\
\hline
\end{tabular}




\subsection{2 - Use Case - Connection}

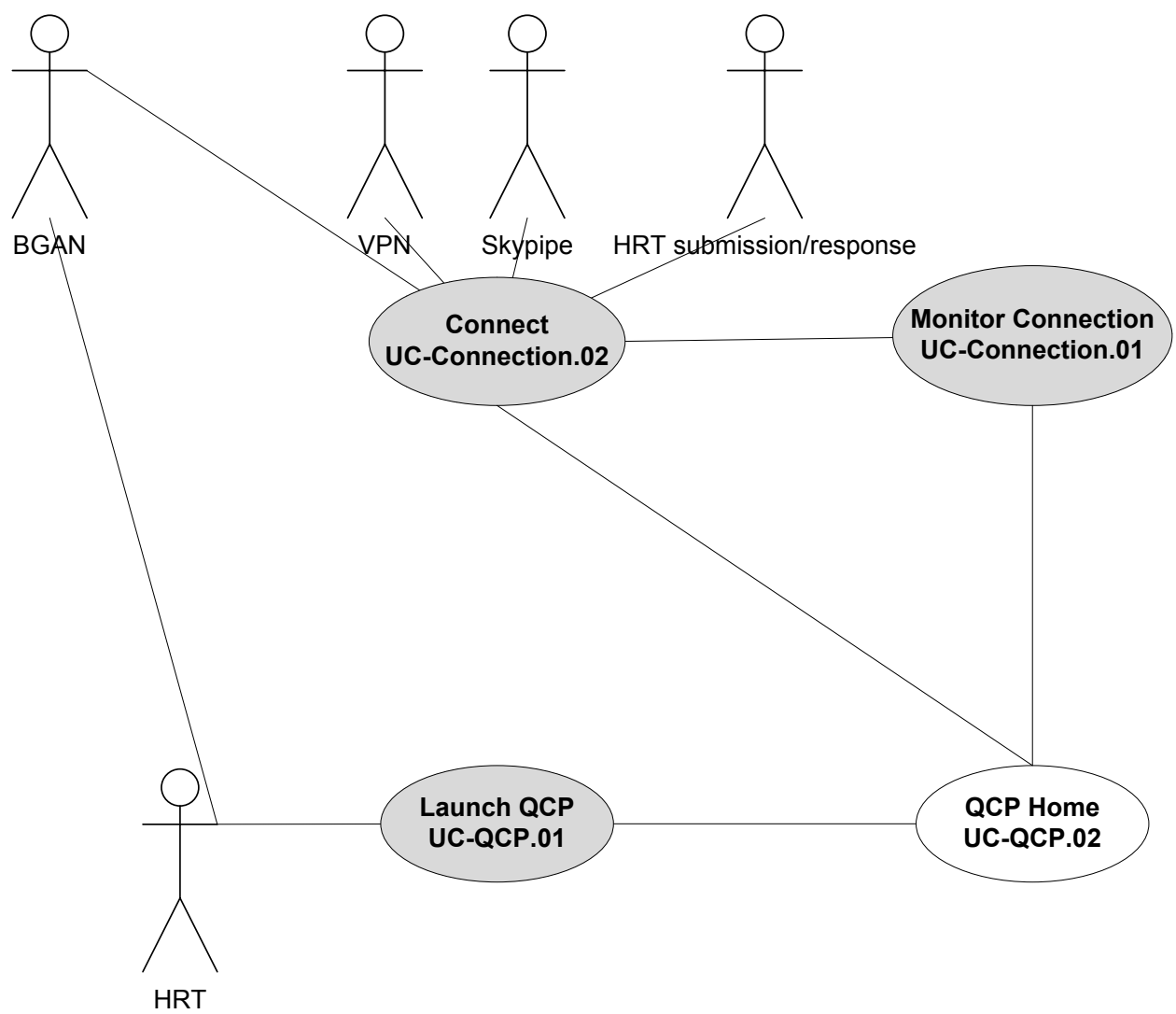

Figure 3 Connection

\subsubsection{UC - Connection.01- Monitor Connection}

\begin{tabular}{|l|l|}
\hline UC-Connect.01 & Monitor Connection \\
\hline Actors & HRT member, BGAN, VPN, Skypipe, HRT submission/response \\
\hline Precondition & QCP application must be launched \\
\hline Postcondition & Connection status indicated \\
\hline Includes & UC - Connection.02 \\
\hline Extends From & \\
\hline Super Use Case & UC - QCP.01 \\
\hline Trigger & Successful launch of QCP application. \\
\hline Description & \\
\hline
\end{tabular}


QCP application will continuously monitor the network connection and indicate the statuses of all connection components.

\begin{tabular}{|c|c|}
\hline Process Descript & \\
\hline $\begin{array}{l}\text { Primary Process } \\
\text { Scenario }\end{array}$ & Monitor Network Connection on QCP Home \\
\hline Step 1 & $\begin{array}{l}\text { QCP application: } \\
\text { - Checks to see if the BGAN network cable is connected to QCP } \\
\text { hardware } \\
\text { - Checks to see if the VPN account is active } \\
\text { - Checks to see if the Skypipe is active } \\
\text { - Checks to see if the HRT submission/response software is active } \\
\text { - Starts submitting any "Transmitted" transactions from the } \\
\text { - Checks to see if there is a response to a submitted transaction }\end{array}$ \\
\hline Step 2 & 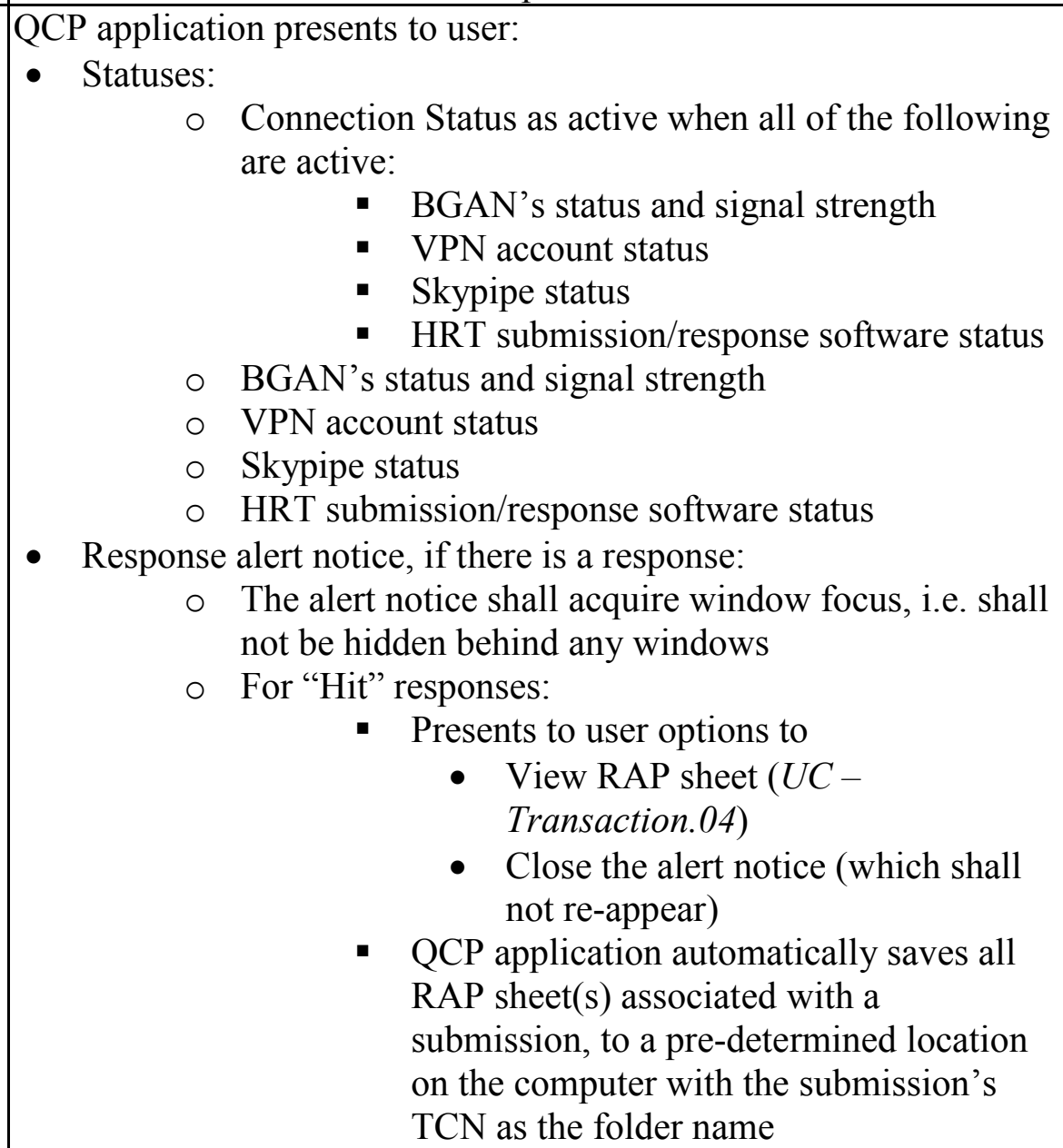 \\
\hline
\end{tabular}




\begin{tabular}{|c|c|}
\hline & $\begin{aligned} \circ \quad \begin{array}{l}\text { For "Rejected" responses, presents to user option to } \\
\text { close the alert notice (which shall not re-appear) }\end{array} \\
\circ \quad \text { For any given transaction submitted, the alert notice } \\
\text { for one response type ("Hit" or "Reject") shall only } \\
\text { appear once, regardless of the databases that the } \\
\text { response comes from (see details in Notes below). }\end{aligned}$ \\
\hline Step 3 & $\begin{array}{l}\text { Primary scenario in } U C-\text { Connection. } 02 \text {, if user chooses Reconnect } \\
\text { option in step } 1\end{array}$ \\
\hline $\begin{array}{l}\text { Exceptions, Error } \\
\text { Situations: }\end{array}$ & 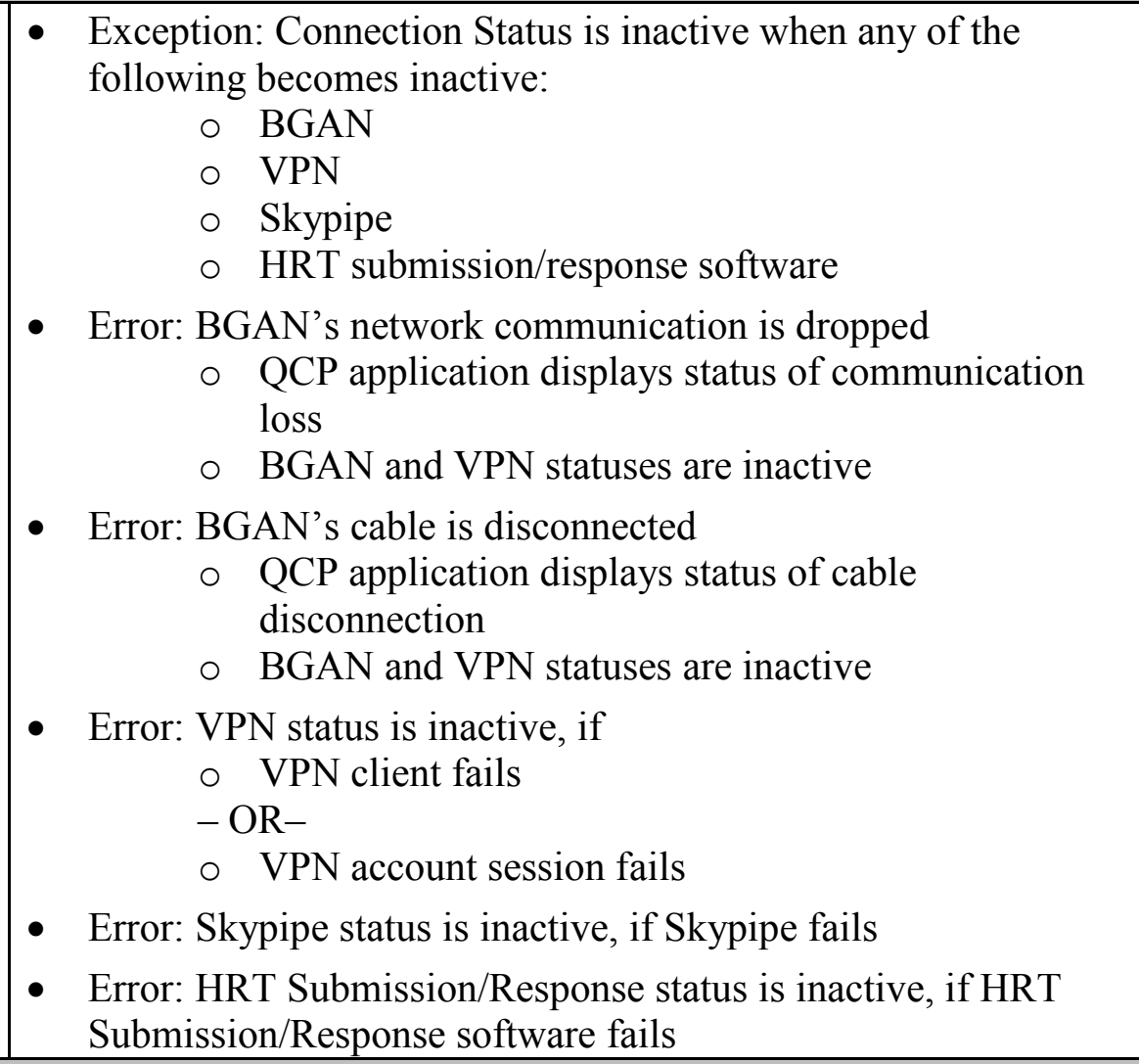 \\
\hline $\begin{array}{l}\text { Alternate Process } \\
\text { Scenario } 1\end{array}$ & Monitor Network Connection (not on QCP Home) \\
\hline Step 1 & Same as step 1 in primary scenario. \\
\hline Step 2 & $\begin{array}{l}\text { QCP application presents to user: } \\
\text { - Statuses: } \\
\circ \text { BGAN's status and signal strength } \\
\circ \text { Connection Status as active when all of the following }\end{array}$ \\
\hline
\end{tabular}




\begin{tabular}{|c|c|}
\hline & $\begin{array}{l}\text { are active: } \\
\text { - BGAN's status and signal strength } \\
\text { - VPN account status } \\
\text { - Skypipe status } \\
\text { - HRT submission/response software status } \\
\text { - Option to re-connect ( } U C-\text { Connection.02), if Connection } \\
\text { Status is inactive }\end{array}$ \\
\hline $\begin{array}{l}\text { Exceptions, Error } \\
\text { Situations: }\end{array}$ & Same as the primary scenario. \\
\hline \multicolumn{2}{|l|}{ Open Issues/Notes } \\
\hline \multicolumn{2}{|c|}{$\begin{array}{l}\text { Regarding the response alert notices for a transaction submitted, for any response type ("Hit" or } \\
\text { "Reject"), only one alert notice shall appear: } \\
\text { 1. When the first response comes in from any database, an alert notice will appear. } \\
\text { 2. For any subsequent responses, an alert notice may or may not appear: an alert notice will } \\
\text { appear only if the response is of different response type. For example, if the first } \\
\text { response was a "Hit" and the } 2^{\text {nd }} \text { response was also a "Hit", then the } 2^{\text {nd }} \text { response (or any } \\
\text { other subsequent "Hit" responses) will not trigger an alert notice to appear. If the first } \\
\text { response was a "Hit" and the } 2^{\text {nd }} \text { response was a "Reject", then there will be alert notices } \\
\text { for both the } 1^{\text {st }} \text { response and the } 2^{\text {nd }} \text { response as they are of different response types. }\end{array}$} \\
\hline
\end{tabular}

\subsubsection{UC - Connection.02 - Connect}

\begin{tabular}{|l|l|}
\hline UC-Connect.02 & Connect \\
\hline Actors & HRT member, BGAN, VPN, Skypipe, HRT submission/response \\
\hline Precondition & $\begin{array}{l}\text { BGAN must be turned on and be connected to QCP hardware; QCP } \\
\text { application must be launched }\end{array}$ \\
\hline Postcondition & A network connection is established. \\
\hline Includes & \\
\hline Extends From & UC - Connection.01- Monitor Connection \\
\hline Super Use Case & \\
\hline Trigger & $\begin{array}{l}\text { Successful launch of QCP application; BGAN is on and connected to } \\
\text { QCP hardware. }\end{array}$ \\
\hline Description & $\begin{array}{l}\text { Upon BGAN connection, QCP application will check for BGAN's status to be "Data," then } \\
\text { QCP application will launch VPN client, Skypipe, and HRT submission/response software, in } \\
\text { order, and one at a time. }\end{array}$ \\
\hline \begin{tabular}{l} 
Process Description \\
\hline
\end{tabular}
\end{tabular}




\begin{tabular}{|c|c|}
\hline $\begin{array}{l}\text { Primary Process } \\
\text { Scenario }\end{array}$ & Network Connection \\
\hline Step 1 & $\begin{array}{l}\text { QCP application: } \\
\text { - Checks to see if the BGAN network cable is connected to QCP } \\
\text { hardware } \\
\text { - checks to see if the status is "Data" }\end{array}$ \\
\hline Step 2 & $\begin{array}{l}\text { QCP application launches VPN and passes QCP default username } \\
\text { and default password to VPN. }\end{array}$ \\
\hline Step 3 & $\begin{array}{l}\text { - User selects a connection entry and starts connecting to VPN } \\
\text { - Optionally, user overwrites the default username and password } \\
\text { - VPN server authenticates user }\end{array}$ \\
\hline Step 4 & QCP application launches Skypipe. \\
\hline Step 5 & $\begin{array}{l}\text { - QCP application launches HRT submission/response software. } \\
\text { - Upon successful launch, all HRT submissions/response software } \\
\text { windows shall be minimized. }\end{array}$ \\
\hline $\begin{array}{l}\text { Exceptions, Error } \\
\text { Situations: }\end{array}$ & $\begin{array}{l}\text { - Error: VPN authentication fails } \\
\quad \text { O QCP application halts until VPN authentication } \\
\text { success }\end{array}$ \\
\hline Open Issu & \\
\hline
\end{tabular}




\subsection{3 - Use Case - Personal Data}

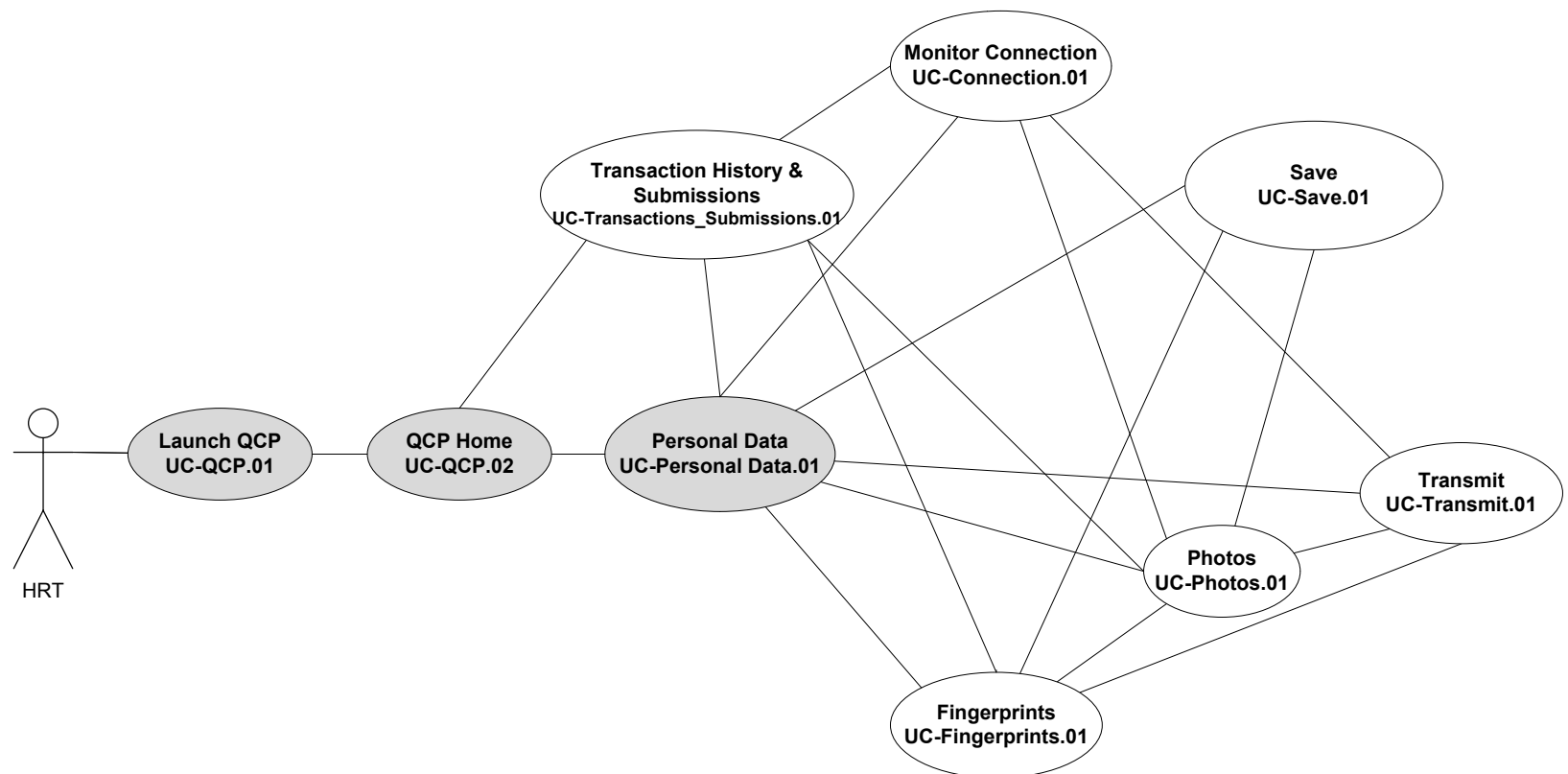

Figure 4 Personal Data

\subsubsection{UC - Personal Data.01}

\begin{tabular}{|l|l|}
\hline UC- Personal Data.01 & Personal Data \\
\hline Actors & HRT member \\
\hline Precondition & QCP application successfully launched \\
\hline Postcondition & Personal data details displayed \\
\hline Includes & UC - Connection.01 \\
\hline Extends From & \\
\hline Super Use Case & UC - QCP.01 \\
\hline Trigger & User decides to access personal data feature of the QCP application. \\
\hline Description & $\begin{array}{l}\text { The Personal Data area provides information pertaining to the biometric presenter and the } \\
\text { nature of the operation. Data entry fields are presented for editable transactions such as new } \\
\text { transactions, untransmitted transactions and transactions being updated. For transmitted } \\
\text { transaction, data will be presented in a view-only manner. }\end{array}$ \\
\hline Process Description \\
\hline $\begin{array}{l}\text { Primary Process } \\
\text { Scenario }\end{array}$ & Personal Data Entry for a New Transaction \\
\hline
\end{tabular}




\begin{tabular}{|c|c|}
\hline Step 1 & 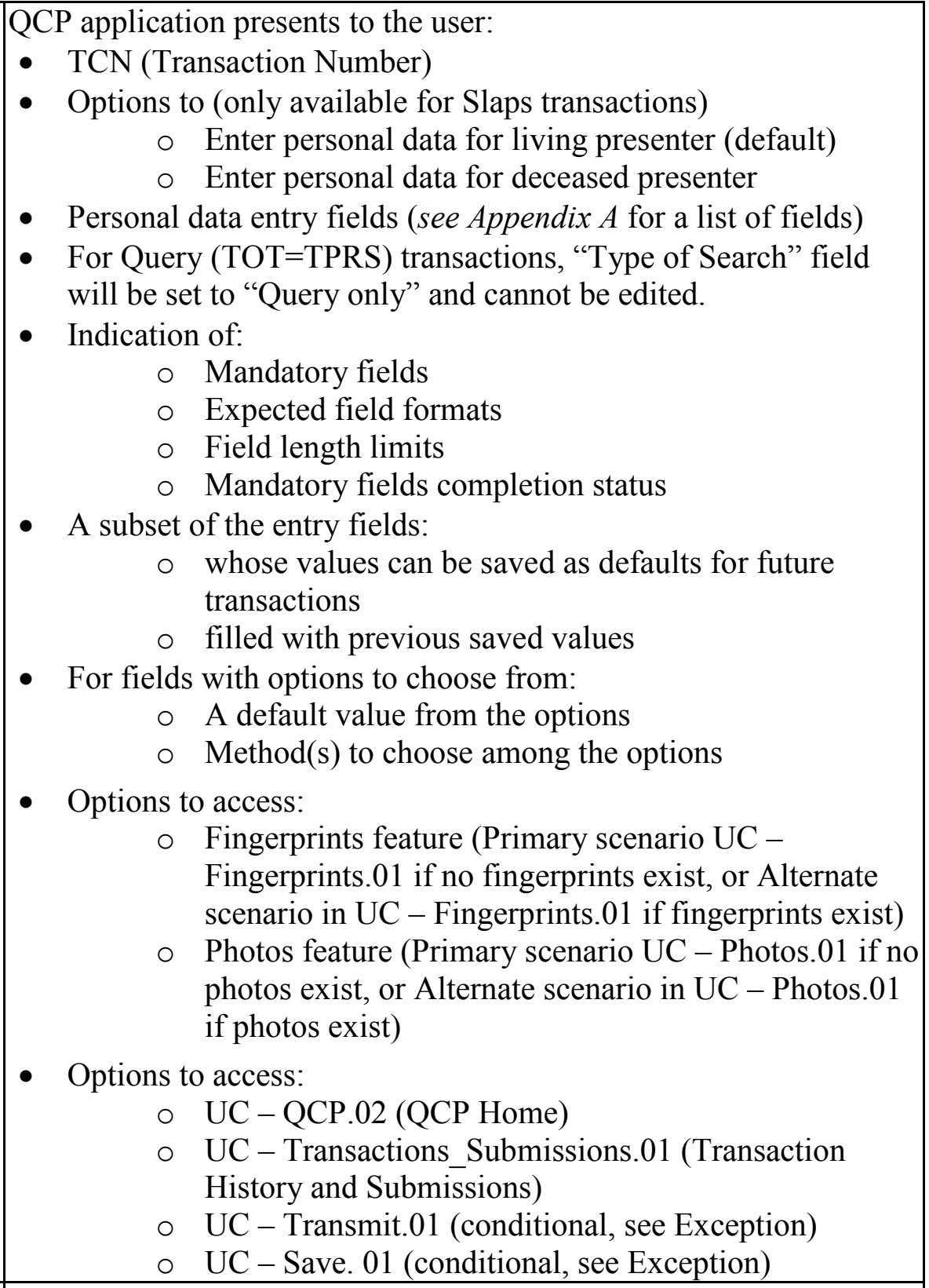 \\
\hline Step 2 & User fills in an entry field. \\
\hline
\end{tabular}




\begin{tabular}{|c|c|}
\hline Step 3 & $\begin{array}{l}\text { QCP application presents to the user: } \\
\text { - Indication of mandatory fields completion status } \\
\text { - For a subset of text entry fields (see Appendix } A \text { ): } \\
\text { o "Predictive text entry" - as the user types characters } \\
\text { into an entry field, the QCP application shall display } \\
\text { any previously entered values that start with the } \\
\text { entered characters for user to choose from. }\end{array}$ \\
\hline Step 4 & $\begin{array}{l}\text { Repeat steps 2-3 until all mandatory fields are entered, if desired. } \\
\text { - There shall be a method to sequentially navigate among the } \\
\text { entry fields, following the order presented in Appendix } A \text {. }\end{array}$ \\
\hline $\begin{array}{l}\text { Exceptions, Error } \\
\text { Situations: }\end{array}$ & $\begin{array}{l}\text { - Exception: "Transmit" will only be available - } \\
\circ \text { when all mandatory data (including personal data, and } \\
\text { fingerprints) are completed } \\
\circ \text { HRT Submission/Response software is available } \\
\text { - Exception: "Save" will only be available - } \\
\circ \text { when there are changes made since data was last } \\
\text { saved } \\
\text { - Error: For date fields, the application shall display an error } \\
\text { indication if user enters: } \\
\circ \text { A month - } \\
\text { - Greater than } 12 \\
\text { - Less than } 1 \\
\text { - Less than } 1 \\
\text { - Greater than the number of days in a } \\
\text { Error: the application shall display an error indication if user } \\
\text { enters characters exceeding the field length limits. }\end{array}$ \\
\hline $\begin{array}{l}\text { Alternate Process } \\
\text { Scenario } 1\end{array}$ & $\begin{array}{l}\text { Personal Data Entry of Deceased Presenter for a New } \\
\text { Slaps Transaction }\end{array}$ \\
\hline Step 1 & User chooses to enter personal data for deceased presenter. \\
\hline Step 2 & $\begin{array}{l}\text { QCP application pre-fills the name fields as the following: } \\
\text { - Last Name: "Unknown" } \\
\text { - Middle Name: "X" } \\
\text { - First Name: "X" }\end{array}$ \\
\hline Step 3 & Same as Steps 2-4 as in primary scenario. \\
\hline
\end{tabular}




\begin{tabular}{|c|c|}
\hline $\begin{array}{l}\text { Alternate Scenario } \\
\text { Exceptions: }\end{array}$ & $\begin{array}{l}\text { - Same as in primary scenario. } \\
\text { - Exception: if user decides not to enter personal data for } \\
\text { deceased presenter, QCP application shall remove the X's from } \\
\text { the name fields and proceed as in primary scenario of } U C- \\
\text { Personal Data.01. }\end{array}$ \\
\hline $\begin{array}{l}\text { Alternate Process } \\
\text { Scenario } 2\end{array}$ & $\begin{array}{l}\text { Personal Data Entry for an Existing, Untransmitted } \\
\text { Transaction }\end{array}$ \\
\hline Step 1 & 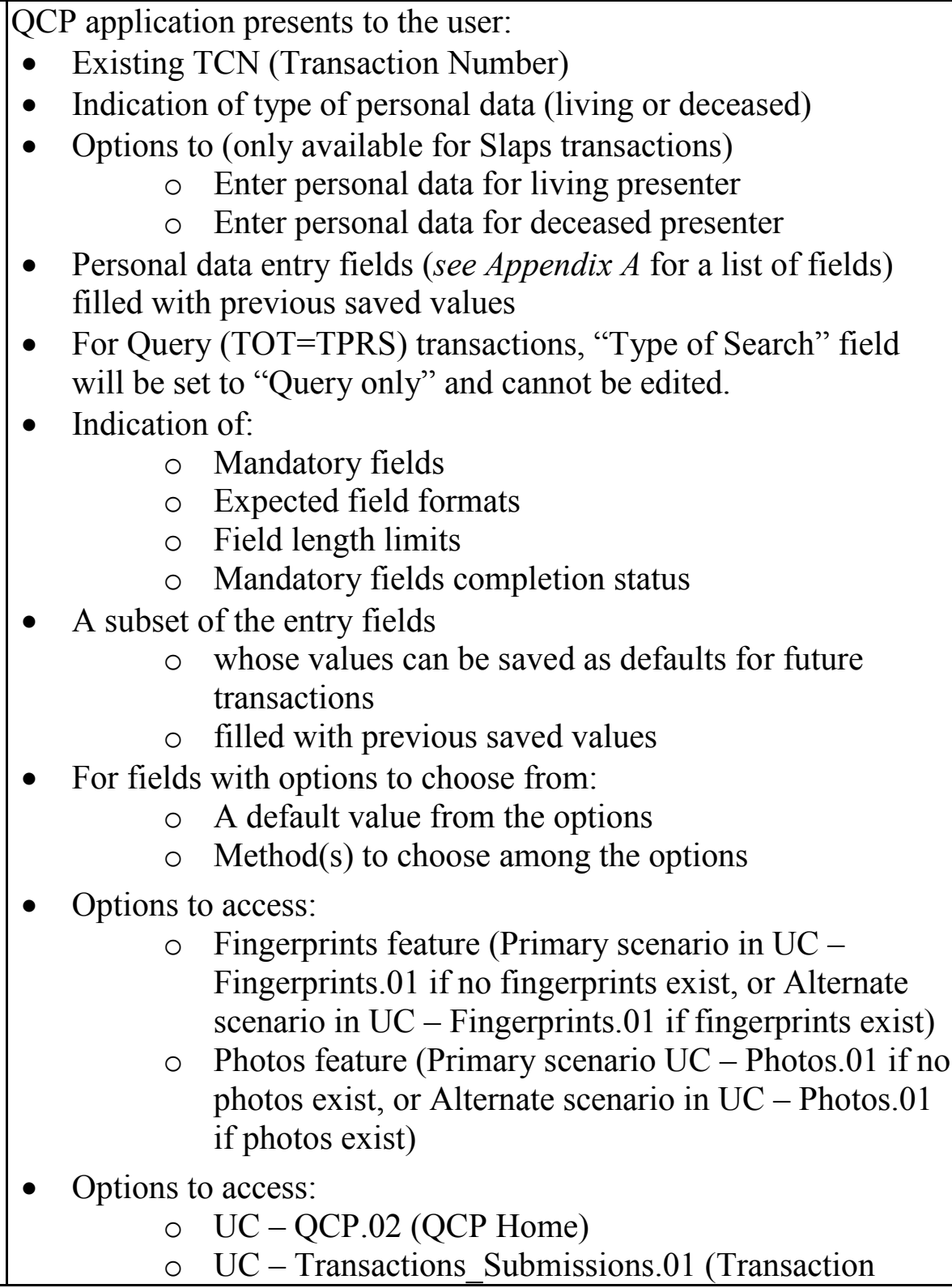 \\
\hline
\end{tabular}




\begin{tabular}{|c|c|}
\hline & $\begin{array}{ll} & \text { History and Submissions) } \\
\circ & \text { UC - Transmit.01 (conditional, see Exception) } \\
\circ & \text { UC - Save. } 01 \text { (conditional, see Exception) }\end{array}$ \\
\hline Step 2 & $\begin{array}{l}\text { - Steps 2-4 as in primary scenario, if for living presenter. } \\
\text { - Steps 2-3 as in alternate scenario } 1 \text {, if for deceased presenter. }\end{array}$ \\
\hline $\begin{array}{l}\text { Alternate Scenario } \\
\text { Exceptions: }\end{array}$ & Same as in primary scenario. \\
\hline $\begin{array}{l}\text { Alternate Process } \\
\text { Scenario } 3\end{array}$ & View only Personal Data for a Transmitted Transaction \\
\hline Step 1 & $\begin{array}{l}\text { QCP application presents to the user: } \\
\text { - } \quad \text { Existing TCN (Transaction Number) } \\
\text { - Indication of type of personal data (living or deceased) } \\
\text { - } \text { of fielditable Personal data entry fields (see Appendix A for a list } \\
\text { - Options to access: } \\
\text { o Fingerprints feature (Alternate scenario } 1 \text { in UC - } \\
\text { Fingerprints.04) } \\
\circ \text { Photos feature (Alternate scenario in UC - Photos.04) } \\
\circ \text { View RAP sheet for a "Hit" response (Alternate } \\
\text { scenario } 2 \text { UC - Transaction.04) } \\
\text { - Options to access: } \\
\text { O UC - QCP.02 (QCP Home) } \\
\circ \text { UC - Transactions_Submissions.01 (Transaction } \\
\text { History and Submissions) } \\
\text { - Option to Update the transaction (UC-Transaction.03) }\end{array}$ \\
\hline $\begin{array}{l}\text { Alternate Scenario } \\
\text { Exceptions: } \\
\text { Open Issues/Notes }\end{array}$ & Same as in primary scenario. \\
\hline
\end{tabular}




\subsection{4 - Use Case - Capture Fingerprints}

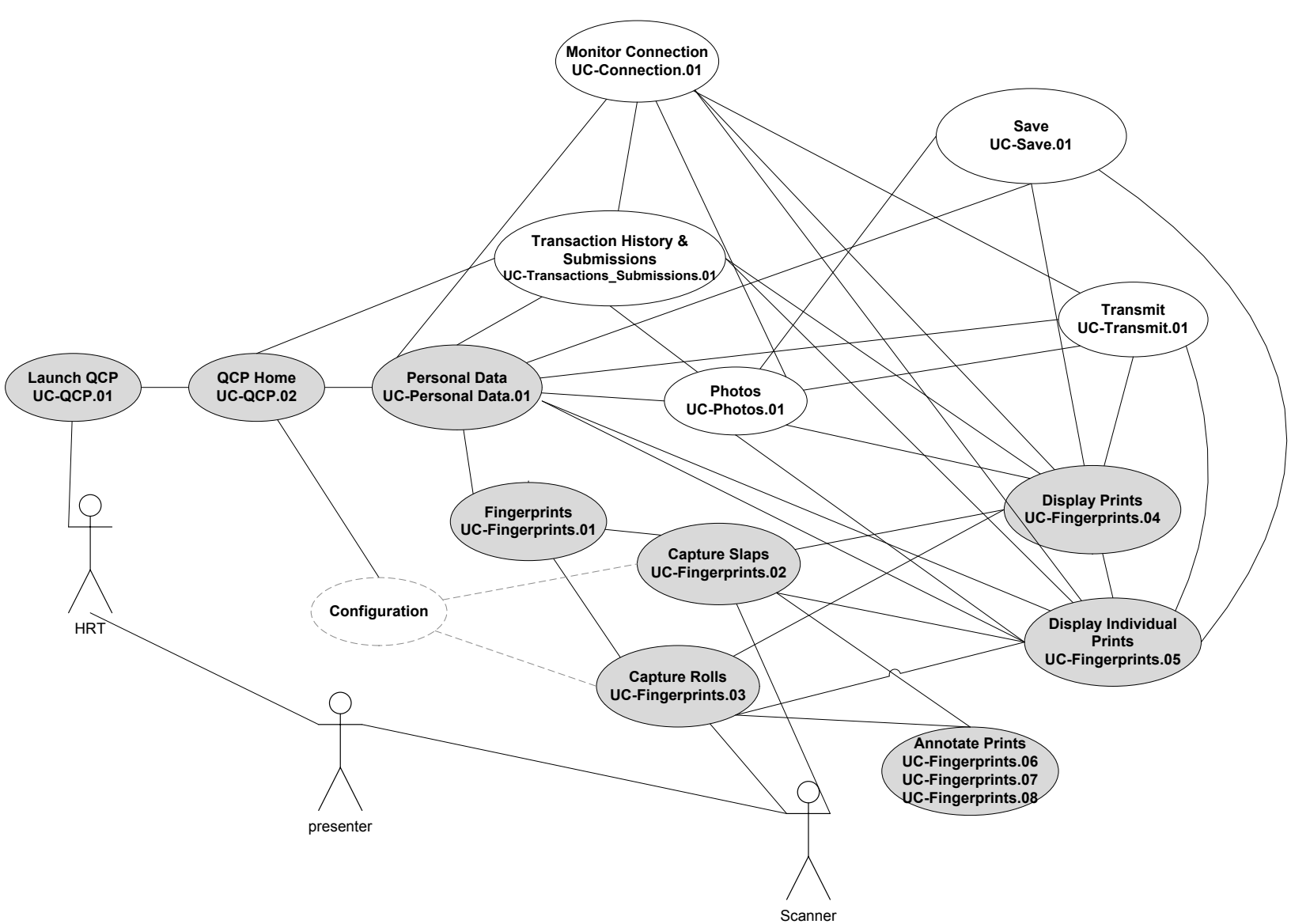

Figure 5 Capture Fingerprints (Slap, Rolls, Display, and Annotation)

\subsubsection{UC - Fingerprints. 01}

\begin{tabular}{|l|l|}
\hline UC- Fingerprints.01 & Fingerprints \\
\hline Actors & HRT member \\
\hline Precondition & QCP application successfully launched \\
\hline Postcondition & Fingerprints displayed \\
\hline Includes & \\
\hline Extends From & \\
\hline Super Use Case & UC - QCP.01 \\
\hline Trigger & User decides to access fingerprints feature of the QCP application. \\
\hline Description & \\
\hline
\end{tabular}




\begin{tabular}{|c|c|}
\hline \multicolumn{2}{|c|}{$\begin{array}{l}\text { The Fingerprints area pro } \\
\text { fingerprints. }\end{array}$} \\
\hline \multicolumn{2}{|c|}{ Process Description } \\
\hline $\begin{array}{l}\text { Primary Process } \\
\text { Scenario }\end{array}$ & New Fingerprints \\
\hline Step 1 & $\begin{array}{l}\text { QCP application presents to the user: } \\
\text { - An indication of the scanner readiness }\end{array}$ \\
\hline Step 2 & $\begin{array}{l}\text { - UC-Fingerprints.02 if user selects create new slaps transaction } \\
\text { option in UC- QCP.01. } \\
\text { - UC-Fingerprints.03 if user selects create new rolls transaction } \\
\text { option in UC - QCP.01. }\end{array}$ \\
\hline $\begin{array}{l}\text { Exceptions, Error } \\
\text { Situations: }\end{array}$ & $\begin{array}{l}\text { - Error: scanner is not connected } \\
\circ \text { QCP application indicates the disconnection of the } \\
\text { scanner and prompts the user to connect the scanner } \\
\circ \text { The options to capture slaps or rolls are inactive } \\
\text { - Error: scanner fails } \\
\circ \text { QCP application indicates the failure of the scanner } \\
\circ \text { The options to capture slaps or rolls are inactive }\end{array}$ \\
\hline $\begin{array}{l}\text { Alternate Process } \\
\text { Scenario }\end{array}$ & Existing Fingerprints \\
\hline Step 1 & UC-Fingerprints.04 to display fingerprints. \\
\hline Open Issues/Notes & \\
\hline
\end{tabular}

\subsubsection{UC - Fingerprints.02}

\begin{tabular}{|l|l|}
\hline UC- Fingerprints.02 & Capture Slaps \\
\hline Actors & HRT member, Presenter, Scanner \\
\hline Precondition & The user has chosen the fingerprints feature of QCP application. \\
\hline Postcondition & The slaps capturing process is completed. \\
\hline Includes & UC - Connection.01 \\
\hline Extends From & \\
\hline Super Use Case & UC - Fingerprints.01 \\
\hline Trigger & The user selects Capture Slaps option in UC - QCP.01. \\
\hline Description & \\
\hline
\end{tabular}


The Capture Slaps process provides a pre-determined slaps capture sequence and the opportunity to annotate any prints.

\begin{tabular}{|c|c|}
\hline \multicolumn{2}{|c|}{ Process Description } \\
\hline $\begin{array}{l}\text { Primary Process } \\
\text { Scenario }\end{array}$ & Initial fingerprint capture \\
\hline Step 1 & $\begin{array}{l}\text { QCP application presents to the user: } \\
\text { - List of capture sequence } \\
\text { - An indication of what the currently expected print is, with option } \\
\text { for user to choose different expected print } \\
\text { - A display of platen and active capture area } \\
\text { - The capture status of any print } \\
\text { - Options to: } \\
\circ \text { Annotate any prints (UC - Fingerprints.06) } \\
\circ \text { Modify annotations (UC - Fingerprints.08) } \\
\text { - Options to: } \\
\circ \text { Determine fingerprint capture process completion } \\
\circ \text { Cancel fingerprint capture process }\end{array}$ \\
\hline Step 2 & $\begin{array}{l}\text { - Presenter places requested print on scanner platen. } \\
\text { - QCP application displays to the user: } \\
\circ \text { print image from scanner } \\
\circ \text { indication if the print is outside of the active capture } \\
\text { area }\end{array}$ \\
\hline Step 3 & $\begin{array}{l}\text { - Scanner captures the print image after it determines that the print } \\
\text { image is acceptable } \\
\text { - Scanner sends the print image to QCP application for process }\end{array}$ \\
\hline Step 4 & $\begin{array}{l}\text { QCP application presents to the user: } \\
\text { - Indication of the next expected print in the capture sequence: } \\
\circ \quad \text { The next expected print is the first uncaptured or } \\
\text { unannotated print in the sequence }\end{array}$ \\
\hline Step 5 & $\begin{array}{l}\text { Repeat steps } 1 \text { to } 3 \text { until: } \\
\text { - All print images are captured or annotated } \\
\text {-OR- } \\
\text { - User determines fingerprint capture process completion } \\
\text {-OR- } \\
\text { - User cancels fingerprint capture process. QCP application } \\
\text { presents to the user: } \\
\text { O a request to confirm cancellation indicating prints and } \\
\text { annotations from the current capture process will not } \\
\text { be saved }\end{array}$ \\
\hline
\end{tabular}




\begin{tabular}{|c|c|}
\hline & $\begin{array}{ll}\circ & \begin{array}{l}\text { Alternate scenario } 2 \text { in UC - Fingerprints.04, upon } \\
\text { user confirmation }\end{array} \\
\end{array}$ \\
\hline Step 6 & UC-Fingerprints.04 (Display Fingerprints) \\
\hline $\begin{array}{l}\text { Exceptions, Error } \\
\text { Situations: }\end{array}$ & $\begin{array}{l}\text { - Exception: a print image is rejected, QCP application displays to } \\
\text { the user: } \\
\circ \text { the reason for rejection } \\
\circ \text { option to retake or accept the print image } \\
\text { - Exception: a print is missing, QCP application prompts user to } \\
\text { annotate (UC - Fingerprints.07). } \\
\text { - Error: scanner fails } \\
\circ \text { QCP application indicates the failure of the scanner } \\
\circ \text { The options to capture slaps or rolls are inactive }\end{array}$ \\
\hline $\begin{array}{l}\text { Alternate Process } \\
\text { Scenario }\end{array}$ & Fingerprint modification \\
\hline Step 1 & $\begin{array}{l}\text { Initially, QCP application presents to the user: } \\
\text { - List of capture sequence that includes only the selected prints: } \\
\circ \text { The selected prints shall follow their relative positions } \\
\text { in the original capture sequence. } \\
\circ \text { If selected prints are part of a slap, then the associated } \\
\text { slap will be in the capture sequence (rather than the } \\
\text { individual prints), e.g. right slap if right middle finger } \\
\text { and right ring finger were selected. } \\
\text { - The capture status of the selected prints in the capture sequence: } \\
\circ \quad \text { Selected prints that have existing print images will be } \\
\text { marked as uncaptured. } \\
\circ \text { Selected prints that have existing annotations will } \\
\text { retain the annotations and be marked as annotated. }\end{array}$ \\
\hline Step 2 & $\begin{array}{l}\text { QCP application presents to the user: } \\
\text { - An indication of what the currently expected print is, with an } \\
\text { option for user to choose a different expected print. } \\
\text { - An indication of annotation for the annotated print(s), if any } \\
\text { - A display of platen and active capture area. } \\
\text { - The capture status of any print (captured, uncaptured, or } \\
\text { annotated). } \\
\text { - Options to: } \\
\circ \text { Annotate any prints (UC - Fingerprints.06) } \\
\circ \text { Modify/Remove annotations (UC - Fingerprints.08) }\end{array}$ \\
\hline
\end{tabular}




\begin{tabular}{|c|c|}
\hline & $\begin{array}{l}\text { - Options to: } \\
\circ \text { Determine fingerprint capture process completion } \\
\circ \text { Cancel fingerprint capture process }\end{array}$ \\
\hline Step 3 & $\begin{array}{l}\text { For the current expected print: } \\
\text { - If the capture status is uncaptured: } \\
\circ \text { Same as in steps } 2 \text { to } 3 \text { in primary scenario for } \\
\text { capturing the print. } \\
\circ \text {-OR- } \\
\circ \text { User may decide to annotate (UC - Fingerprints.06). } \\
\text { - If the capture status is annotated: } \\
\circ \text { User can modify or remove the annotation (UC - } \\
\text { Fingerprints.08). }\end{array}$ \\
\hline Step 4 & $\begin{array}{l}\text { - QCP application updates the capture status of the print. } \\
\text { QCP application advances to the next expected print in the } \\
\text { capture sequence. }\end{array}$ \\
\hline Step 5 & $\begin{array}{l}\text { Repeat steps } 2 \text { to } 4 \text { until: } \\
\text { - All selected print images are captured or annotated. } \\
\text {-OR- } \\
\text { - User determines fingerprint capture process completion. } \\
\text {-OR- } \\
\text { - User cancels fingerprint capture process. QCP application } \\
\text { presents to the user : } \\
\quad \text { a request to confirm cancellation indicating prints and } \\
\text { annotations from the current capture process will not } \\
\text { be saved } \\
\circ \text { Alternate scenario } 2 \text { in UC - Fingerprints.04, upon } \\
\text { user confirmation. }\end{array}$ \\
\hline Step 6 & $\begin{array}{l}\text { Modification results will be reflected in UC-Fingerprints.04 } \\
\text { (display fingerprints). }\end{array}$ \\
\hline $\begin{array}{l}\text { Alternate Scenario } \\
\text { Exceptions: }\end{array}$ & Same as in primary scenario. \\
\hline Open Issues/Notes & \\
\hline
\end{tabular}

\subsubsection{UC - Fingerprints.03}

\section{\begin{tabular}{|l|l|}
\hline UC- Fingerprints.03 & Capture Rolls \\
\hline
\end{tabular}}




\begin{tabular}{|c|c|}
\hline Actors & HRT member, Presenter, Scanner \\
\hline Precondition & The user has chosen the fingerprints feature of QCP application. \\
\hline Postcondition & The rolls capturing process is completed. \\
\hline Includes & UC - Connection.01 \\
\hline \multicolumn{2}{|l|}{ Extends From } \\
\hline Super Use Case & UC - Fingerprints.01 \\
\hline Trigger & The user selects Capture Rolls option in UC-QCP.01. \\
\hline \multicolumn{2}{|l|}{ Description } \\
\hline \multicolumn{2}{|c|}{$\begin{array}{l}\text { The Capture Rolls process provides } \\
\text { to annotate any prints. }\end{array}$} \\
\hline \multicolumn{2}{|c|}{ Process Description } \\
\hline \begin{tabular}{|l} 
Primary Process \\
Scenario
\end{tabular} & Initial fingerprint capture \\
\hline Step 1 & $\begin{array}{l}\text { - List of capture sequence } \\
\text { - An indication of what the currently expected print is, with option } \\
\text { - A display of platen and active capture area } \\
\text { - The capture status of any print } \\
\text { - Options to: } \\
\circ \text { Annotate any prints (UC - Fingerprints. } 06) \\
\circ \text { Modify annotations (UC - Fingerprints.08) } \\
\text { - Options to: } \\
\circ \text { Determine fingerprint capture process completion } \\
\circ \text { Cancel fingerprint capture process }\end{array}$ \\
\hline Step 2 & $\begin{array}{l}\text { - Presenter places requested print on scanner platen } \\
\text { - QCP application displays to the user: } \\
\circ \text { print image from scanner } \\
\circ \quad \text { indication if the print is outside of the active capture } \\
\text { area } \\
\end{array}$ \\
\hline Step 3 & $\begin{array}{l}\text { - Scanner captures the print image after it determines that the print } \\
\text { image is acceptable } \\
\text { - Scanner sends the print image to QCP application for process }\end{array}$ \\
\hline Step 4 & $\begin{array}{l}\text { QCP application presents to the user: } \\
\text { - Indication of the next expected print in the capture sequence: } \\
\circ \text { The next expected print is the first uncaptured or } \\
\text { unannotated print in the sequence }\end{array}$ \\
\hline Step 5 & $\begin{array}{l}\text { Repeat steps } 1 \text { to } 3 \text { until: } \\
\bullet \quad \text { All print images are captured or annotated }\end{array}$ \\
\hline
\end{tabular}




\begin{tabular}{|c|c|}
\hline & $\begin{array}{l}\text {-OR- } \\
\text { - User determines fingerprint capture process completion } \\
\text {-OR- } \\
\text { - User cancels fingerprint capture process. QCP application } \\
\text { presents to the user : } \\
\quad \text { a request to confirm cancellation indicating prints and } \\
\text { annotations from the current capture process will not } \\
\text { be saved } \\
\circ \text { Alternate scenario } 2 \text { in UC - Fingerprints.04, upon } \\
\text { user confirmation }\end{array}$ \\
\hline Step 6 & UC-Fingerprints.04 (Display Fingerprints) \\
\hline $\begin{array}{l}\text { Exceptions, Error } \\
\text { Situations: }\end{array}$ & $\begin{array}{l}\text { - Exception: a print image is rejected, QCP application displays to } \\
\text { the user: } \\
\circ \text { the reason for rejection } \\
\circ \text { option to retake or accept the print image } \\
\text { - Exception: a print is missing, QCP application prompts user to } \\
\text { annotate: } \\
\circ \text { UC - Fingerprints.07 } \\
\text { - Error: scanner fails } \\
\circ \text { QCP application indicates the failure of the scanner } \\
\circ \text { The options to capture slaps or rolls are inactive }\end{array}$ \\
\hline $\begin{array}{l}\text { Alternate Process } \\
\text { Scenario }\end{array}$ & Fingerprint modification \\
\hline Step 1 & $\begin{array}{l}\text { Initially, QCP application presents to the user: } \\
\text { - List of capture sequence that includes only the selected prints: } \\
\circ \text { The selected prints shall follow their relative positions } \\
\text { in the original capture sequence. } \\
\text { - The capture status of the selected prints in the capture sequence: } \\
\circ \text { Selected prints that have existing print images will be } \\
\text { marked as uncaptured. } \\
\circ \quad \text { Selected prints that have existing annotations will } \\
\text { retain the annotations and be marked as annotated. }\end{array}$ \\
\hline Step 2 & $\begin{array}{l}\text { QCP application presents to the user: } \\
\text { - An indication of what the currently expected print is, with an } \\
\text { option for user to choose different expected print } \\
\text { - An indication of annotation for the annotated print(s), if any } \\
\text { - A display of platen and active capture area } \\
\text { - The capture status of any print (captured, uncaptured, or }\end{array}$ \\
\hline
\end{tabular}




\begin{tabular}{|c|c|}
\hline & $\begin{array}{l}\text { annotated) } \\
\text { - Options to: } \\
\circ \text { Annotate any prints (UC - Fingerprints.06) } \\
\circ \text { Modify/Remove annotations (UC - Fingerprints.08) } \\
\text { - Options to: } \\
\circ \text { Determine fingerprint capture process completion } \\
\circ \text { Cancel fingerprint capture process }\end{array}$ \\
\hline Step 3 & $\begin{array}{l}\text { For the current expected print: } \\
\text { - If the capture status is uncaptured: } \\
\circ \text { Same as in steps } 2 \text { to } 3 \text { in primary scenario for } \\
\text { capturing the print. } \\
\circ \text {-OR- } \\
\circ \text { User may decide to annotate (UC - Fingerprints.06). } \\
\text { - If the capture status is annotated: } \\
\text { O User can modify or remove the annotation (UC - } \\
\text { Fingerprints.08). }\end{array}$ \\
\hline Step 4 & $\begin{array}{l}\text { - QCP application updates the capture status of the print. } \\
\text { QCP application advances to the next expected print in the } \\
\text { capture sequence. }\end{array}$ \\
\hline Step 5 & $\begin{array}{l}\text { Repeat steps } 2 \text { to } 4 \text { until: } \\
\text { - All selected print images are captured or annotated. } \\
\text {-OR- } \\
\text { - User determines fingerprint capture process completion. } \\
\text {-OR- } \\
\text { - User cancels fingerprint capture process. QCP application } \\
\text { presents to the user : } \\
\quad \text { a request to confirm cancellation indicating prints and } \\
\text { annotations from the current capture process will not } \\
\text { be saved } \\
\circ \text { Alternate scenario } 2 \text { in UC - Fingerprints.04, upon } \\
\text { user confirmation. }\end{array}$ \\
\hline Step 6 & $\begin{array}{l}\text { Modification results will be reflected in UC-Fingerprints. } 04 \\
\text { (display fingerprints). }\end{array}$ \\
\hline $\begin{array}{l}\text { Alternate Scenario } \\
\text { Exceptions: }\end{array}$ & Same as in primary scenario. \\
\hline Open Issues/Notes & \\
\hline
\end{tabular}




\subsubsection{UC - Fingerprints.04}

\begin{tabular}{|c|c|}
\hline UC- Fingerprints. 04 & Display Fingerprints \\
\hline Actors & HRT member \\
\hline Precondition & QCP application successfully launched \\
\hline Postcondition & All print blocks are presented with either print images or annotations. \\
\hline Includes & UC - Connection. 01 \\
\hline Extends From & UC - Fingerprints. 01 \\
\hline \multicolumn{2}{|l|}{ Super Use Case } \\
\hline Trigger & $\begin{array}{l}\text { Successful capture of print images (UC - Fingerprints. } 02 \text { or UC - } \\
\text { Fingerprints. } 03 \text { ). }\end{array}$ \\
\hline \multicolumn{2}{|l|}{ Description } \\
\hline \multicolumn{2}{|c|}{$\begin{array}{l}\text { The application displays print blocks containing captured print images or annotations with } \\
\text { associated names. }\end{array}$} \\
\hline \multicolumn{2}{|c|}{ Process Description } \\
\hline $\begin{array}{l}\text { Primary Process } \\
\text { Scenario }\end{array}$ & Display of successfully captured print images \\
\hline Step 1 & 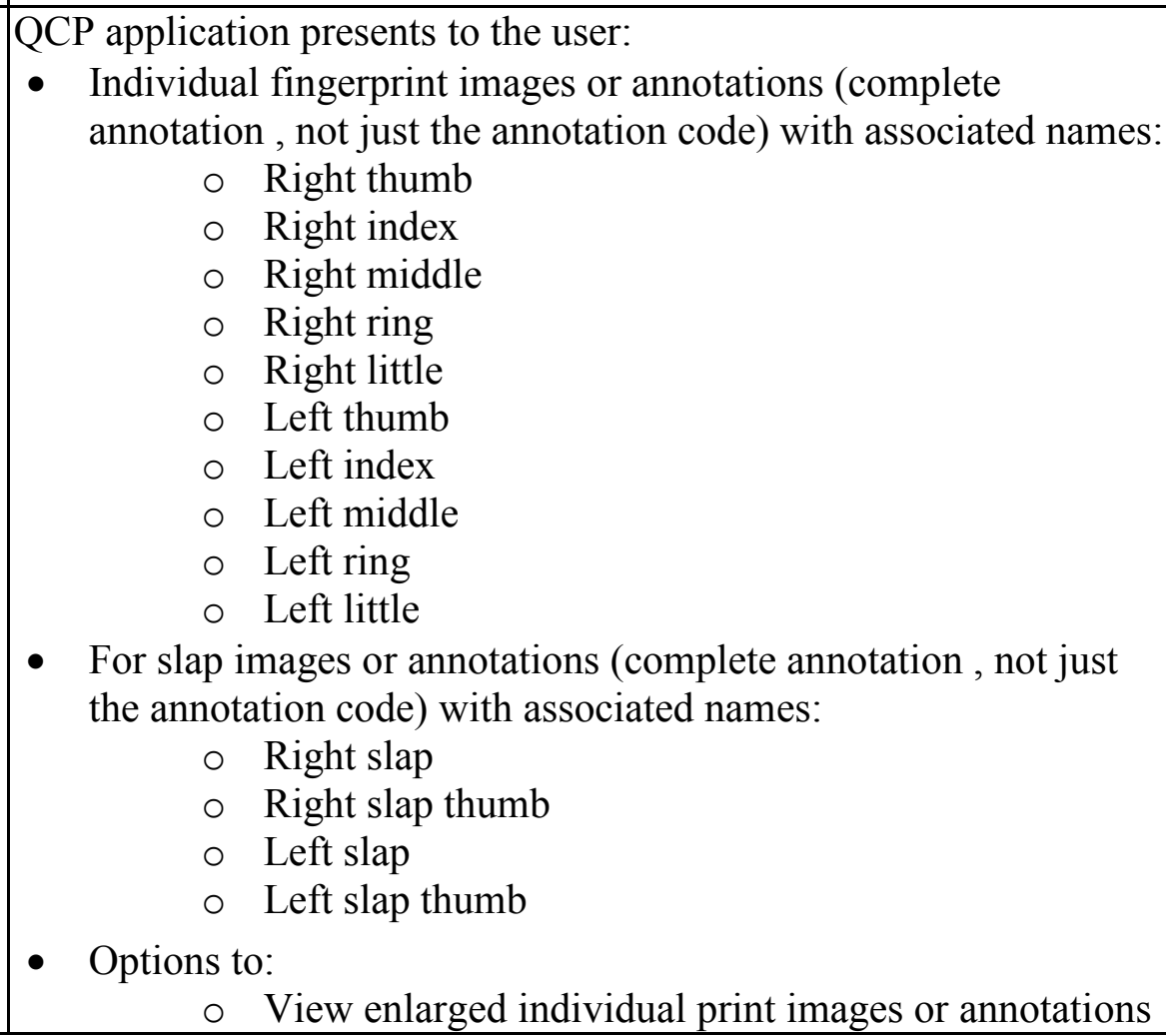 \\
\hline
\end{tabular}




\begin{tabular}{|c|c|}
\hline & $\begin{array}{l}\text { (complete annotation, not just the annotation code) } \\
\text { with associated names (UC - Fingerprints.05) } \\
\text { Modify print(s) } \\
\quad \text { All prints } \\
\quad \text { OR- } \\
\quad \text { Select print(s), i.e. print images or } \\
\text { annotated prints, to modify }\end{array}$ \\
\hline Step 2 & $\begin{array}{l}\text { If user selects print(s) to modify, QCP application presents: } \\
\text { - Indication of the selected } \operatorname{print}(\mathrm{s})\end{array}$ \\
\hline Step 3 & $\begin{array}{l}\text { User decides to start the modification process: } \\
\text { - } \quad \text { Alternate scenario in } U C-\text { Fingerprints. } 02 \text { for slaps } \\
\text { - } \quad \text { Alternate scenario in } U C-\text { Fingerprints. } 03 \text { for rolls }\end{array}$ \\
\hline $\begin{array}{l}\text { Exceptions, Error } \\
\text { Situations: }\end{array}$ & $\begin{array}{l}\text { - Exception: display of print images is determined by the capture } \\
\text { list, so not all print images listed in Step } 1 \text { may be available for } \\
\text { display } \\
\text { - Exception: "Transmit" will only be available - } \\
\text { O when all mandatory data (including personal data, and } \\
\text { fingerprints) are completed } \\
\text { O HRT Submission/Response software is available } \\
\text { - Exception: "Save" will only be available - } \\
\text { O when there are changes made since data was last } \\
\text { saved }\end{array}$ \\
\hline $\begin{array}{l}\text { Alternate Process } \\
\text { Scenario } 1\end{array}$ & $\begin{array}{l}\text { View only display of print images for a transmitted } \\
\text { transaction }\end{array}$ \\
\hline
\end{tabular}




\begin{tabular}{|c|c|}
\hline Step 1 & 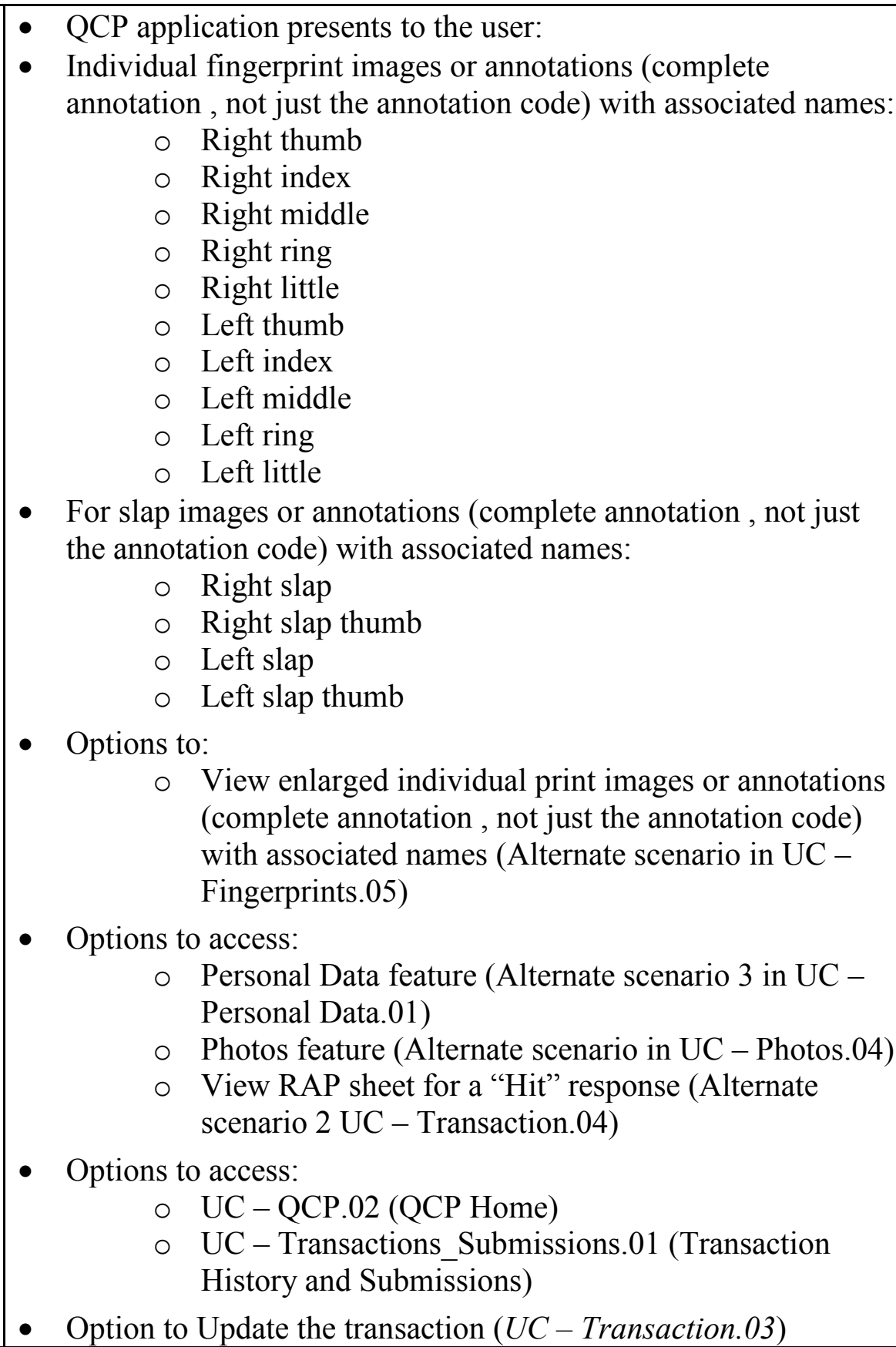 \\
\hline $\begin{array}{l}\text { Alternate Scenario } \\
\text { Exceptions: }\end{array}$ & Same as in primary scenario. \\
\hline
\end{tabular}




\begin{tabular}{|c|c|}
\hline $\begin{array}{l}\text { Alternate Process } \\
\text { Scenario } 2\end{array}$ & Display of print blocks if capture process is cancelled \\
\hline Step 1 & 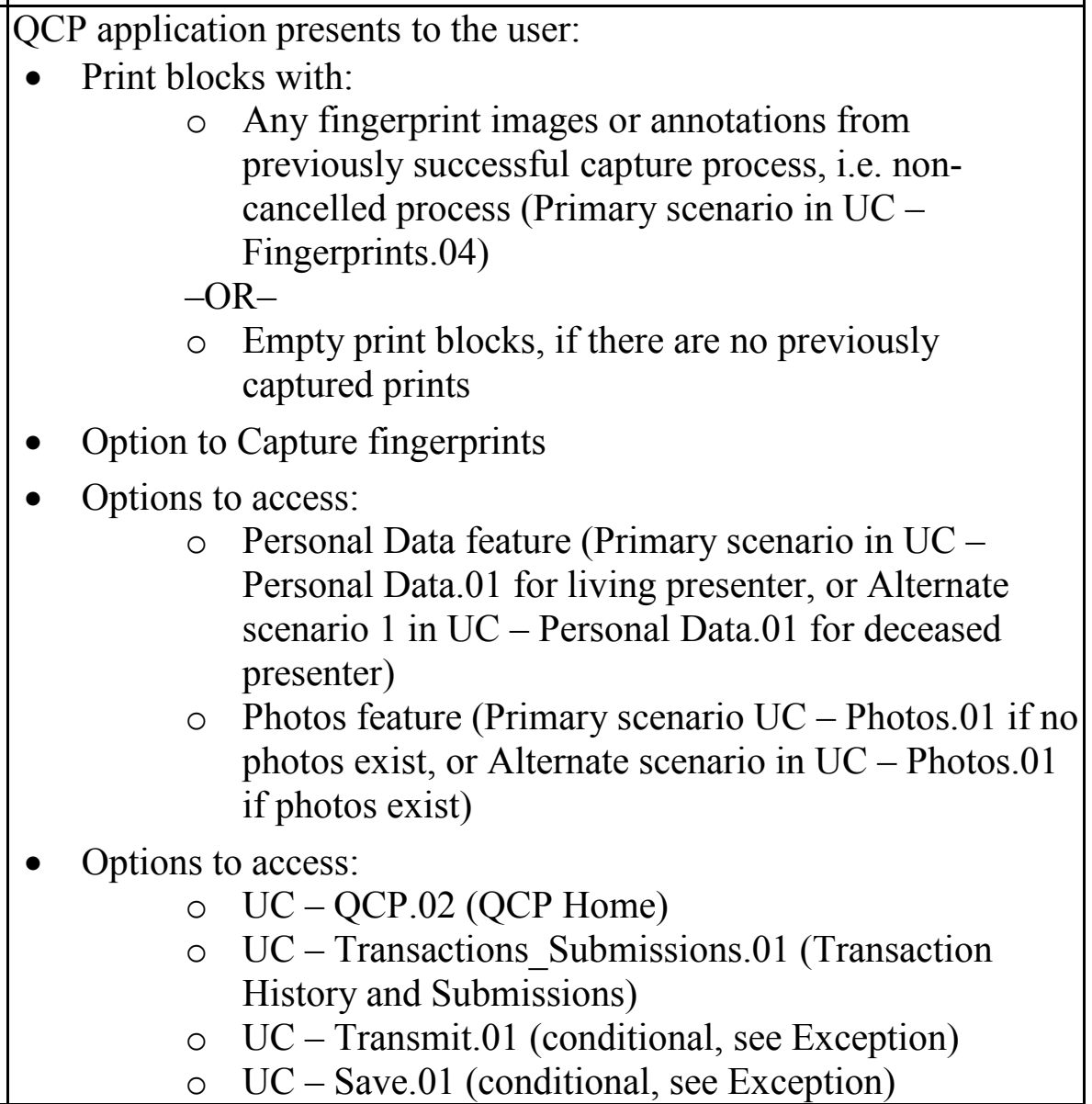 \\
\hline Step 2 & $\begin{array}{l}\text { If user decides to start the fingerprint capture process: } \\
\text { - } \quad \text { Primary scenario in } U C \text { - Fingerprints. } 02 \text { for slaps } \\
\text { - } \quad \text { Primary scenario in UC-Fingerprints. } 03 \text { for rolls } \\
\end{array}$ \\
\hline $\begin{array}{l}\text { Alternate Scenario } \\
\text { Exceptions: }\end{array}$ & $\begin{array}{l}\text { - Exception: "Transmit" will only be available - } \\
\text { ○ when all mandatory data (including personal data, and } \\
\text { fingerprints) are completed } \\
\circ \text { HRT Submission/Response software is available } \\
\text { - Exception: "Save" will only be available - } \\
\text { o when there are changes made since data was last } \\
\text { saved }\end{array}$ \\
\hline Ope & \\
\hline
\end{tabular}


HRT Review (Dec.09,'08) - A big question from HRT, is there a way to indicate if the prints are "good enough" for possible matching? [NIST] This is a complicated issue that can't be solved in the UI design. If some sort of quality checking algorithm can be embedded in the QCP application, it won't be too difficult for the UI to present some feedback to users if any prints are recommended to be re-taken.

\subsubsection{UC - Fingerprints.05}

\begin{tabular}{|c|c|}
\hline UC- Fingerprints.05 & Display Individual Prints \\
\hline Actors & HRT member \\
\hline Precondition & $\begin{array}{l}\text { Successful UC - Fingerprints.04 (Primary scenario and Alternate } \\
\text { scenario 1) }\end{array}$ \\
\hline Postcondition & Individual print images or print annotation displayed \\
\hline Includes & $\mathrm{UC}-$ Connection. 01 \\
\hline Extends From & UC - Fingerprints.04 \\
\hline Super Use Case & \multirow{2}{*}{ User decides to view an enlarged print image or annotated print. } \\
\hline Trigger & \\
\hline \multicolumn{2}{|l|}{ Description } \\
\hline \multicolumn{2}{|c|}{$\begin{array}{l}\text { The application displays enlarged individual print images or annotations with associated names. } \\
\text { Also, navigation among individual prints is provided. }\end{array}$} \\
\hline \multicolumn{2}{|c|}{ Process Description } \\
\hline $\begin{array}{l}\text { Primary Process } \\
\text { Scenario }\end{array}$ & $\begin{array}{l}\text { Display of an enlarged print for an untransmitted } \\
\text { transaction }\end{array}$ \\
\hline Step 1 & $\begin{array}{l}\text { User selects the option to view an enlarged print image or an } \\
\text { annotated print. }\end{array}$ \\
\hline Step 2 & 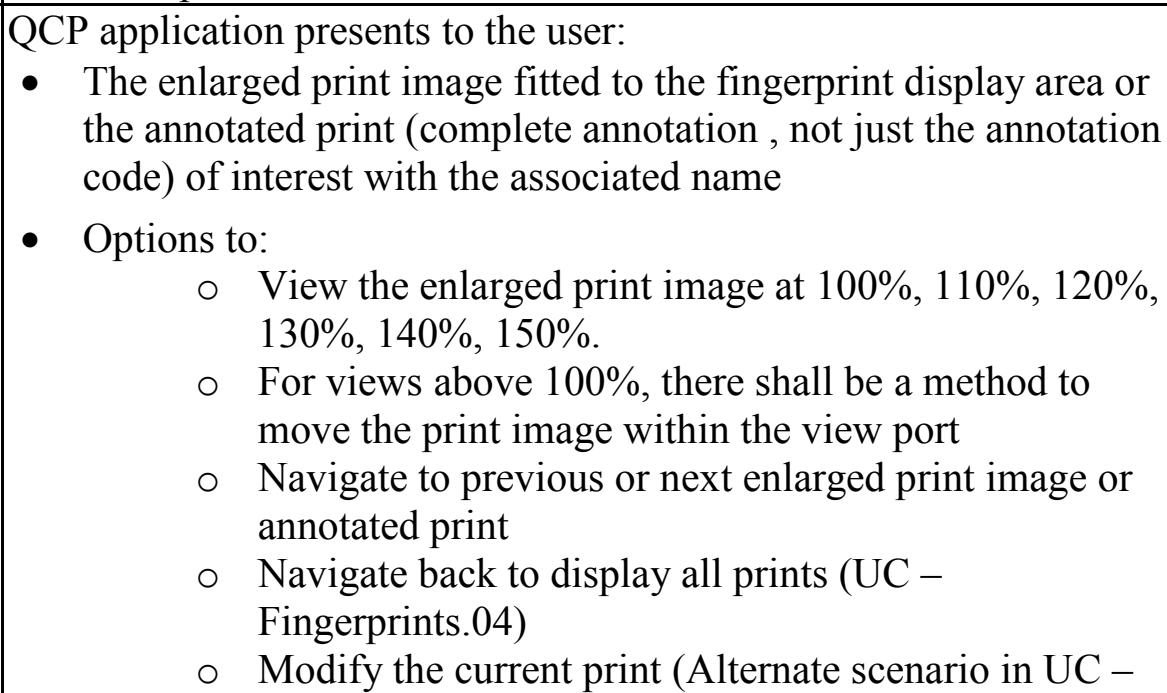 \\
\hline
\end{tabular}




\begin{tabular}{|c|c|}
\hline & $\begin{array}{l}\text { Fingerprints.02 for slaps or alternate scenario in UC - } \\
\text { Fingerprints.03 for rolls) } \\
\text { - Options to access: } \\
\circ \quad \text { Personal Data feature (Primary scenario in UC - } \\
\text { Personal Data.01 for living presenter, or Alternate } \\
\text { scenario 1 in UC - Personal Data.01 for deceased } \\
\text { presenter) } \\
\circ \quad \text { Photos feature (Primary scenario UC - Photos.01 if no } \\
\text { photos exist, or Alternate scenario in UC - Photos.01 } \\
\text { if photos exist) } \\
\text { Options to access: } \\
\circ \quad \text { UC - QCP.02 (QCP Home) } \\
\circ \quad \text { UC - Transactions_Submissions.01 (Transaction } \\
\text { History and Submissions) } \\
\circ \quad \text { UC - Transmit.01 (conditional, see Exception) } \\
\circ \quad \text { UC - Save.01 (conditional, see Exception) }\end{array}$ \\
\hline Step 3 & User chooses one of the options presented. \\
\hline $\begin{array}{l}\text { Exceptions, Error } \\
\text { Situations: }\end{array}$ & $\begin{array}{l}\text { - Exception: "Transmit" will only be available - } \\
\circ \text { when all mandatory data (including personal data, and } \\
\text { fingerprints) are completed } \\
\circ \text { HRT Submission/Response software is available } \\
\text { - Exception: "Save" will only be available - } \\
\circ \text { when there are changes made since data was last } \\
\text { saved }\end{array}$ \\
\hline $\begin{array}{l}\text { Alternate Process } \\
\text { Scenario }\end{array}$ & Display of an enlarged print for a transmitted transaction \\
\hline Step 1 & $\begin{array}{l}\text { User selects the option to view an enlarged print image or an } \\
\text { annotated print }\end{array}$ \\
\hline Step 2 & $\begin{array}{l}\text { QCP application presents to the user: } \\
\text { - The enlarged print image fitted to the fingerprint display area or } \\
\text { the annotated print (complete annotation , not just the annotation } \\
\text { code) of interest with the associated name } \\
\text { - Options to: } \\
\text { O View the enlarged print image at } 100 \%, 110 \%, 120 \% \text {, } \\
130 \%, 140 \%, 150 \% \text {. } \\
\circ \quad \text { For views above } 100 \% \text {, there shall be a method to } \\
\text { move the print image within the view port } \\
\text { Navigate to previous or next enlarged print image or }\end{array}$ \\
\hline
\end{tabular}




\begin{tabular}{|c|c|}
\hline & $\begin{array}{l}\text { annotated print } \\
\circ \quad \text { Navigate back to display all prints (Alternate scenario } \\
1 \text { in UC - Fingerprints.04) } \\
\text { - Options to access: } \\
\circ \quad \text { Personal Data feature (Alternate scenario } 3 \text { in UC - } \\
\text { Personal Data.01) } \\
\circ \quad \text { Photos feature (Alternate scenario in UC - Photos.04) } \\
\circ \quad \text { View RAP sheet for a "Hit" response (Alternate } \\
\text { scenario } 2 \text { in UC - Transaction.04) } \\
\text { - Options to access: } \\
\circ \quad \text { UC - QCP.02 (QCP Home) } \\
\circ \quad \text { UC - Transactions_Submissions.01 (Transaction } \\
\text { History and Submissions) } \\
\text { - Option to Update the transaction (UC - Transaction.03) }\end{array}$ \\
\hline Step 3 & User chooses one of the options presented. \\
\hline s/Notes & \\
\hline
\end{tabular}

\subsubsection{UC - Fingerprints.06}

\begin{tabular}{|l|l|}
\hline UC- Fingerprints.06 & Annotate Prints - User Initiated \\
\hline Actors & HRT member \\
\hline Precondition & QCP application successfully launched \\
\hline Postcondition & User specified prints annotated \\
\hline Includes & \\
\hline Extends From & \\
\hline Super Use Case & UC - Fingerprints.02 or UC - Fingerprints.03 \\
\hline Trigger & The user decides to annotate prints \\
\hline Description & \\
\hline $\begin{array}{l}\text { During fingerprint capture process, user can choose to annotate any prints. The annotated prints } \\
\text { will be skipped from the capture sequence. }\end{array}$ \\
\hline Process Description \\
\hline $\begin{array}{l}\text { Primary Process } \\
\text { Scenario }\end{array}$ & Slap Annotation \\
\hline Step 1 & User chooses a slap print to annotate. \\
\hline Step 2 & $\begin{array}{l}\text { QCP application presents to the user: } \\
\bullet\end{array}$ Options to select individual slap component(s) \\
\hline
\end{tabular}




\begin{tabular}{|c|c|}
\hline & $\begin{array}{l}\text { - Annotation choices for each selected component, choices } \\
\text { available are: } \\
\quad \text { Unable to print (default) } \\
\circ \text { Amputated }\end{array}$ \\
\hline Step 3 & $\begin{array}{l}\text { User decides what slap component(s) to annotate and selects from } \\
\text { annotation choices. }\end{array}$ \\
\hline Step 4 & $\begin{array}{l}\text { QCP application presents to the user: } \\
\text { - Indication of annotation for the annotated slap } \\
\text { - If the capture sequence includes any fingerprints corresponding } \\
\text { to annotated slap components, } \\
\quad \text { indication of annotation for the annotated fingerprints } \\
\circ \text { indication that the fingerprints will be skipped } \\
\text { - If all slap components are annotated, an indication that the slap } \\
\text { will be skipped from the capture sequence }\end{array}$ \\
\hline Step 5 & Repeat steps 1-4 for other slap prints if desired. \\
\hline $\begin{array}{l}\text { Exceptions, Error } \\
\text { Situations: }\end{array}$ & NA \\
\hline $\begin{array}{l}\text { Alternate Process } \\
\text { Scenario }\end{array}$ & Individual Finger Annotation \\
\hline Step 1 & User chooses an individual fingerprint to annotate. \\
\hline Step 2 & $\begin{array}{l}\text { QCP application presents to the user: } \\
\text { - Annotation choices } \\
\circ \text { Unable to print (default) } \\
\circ \text { Amputated }\end{array}$ \\
\hline Step 3 & User selects from annotation choices. \\
\hline Step 4 & $\begin{array}{l}\text { QCP application presents to the user: } \\
\text { - Indication of annotation for the annotated fingerprint } \\
\text { - Indication of annotation for the corresponding slap that includes } \\
\text { the annotated fingerprint } \\
\text { - Indication that the annotated print will be skipped from the } \\
\text { capture sequence } \\
\text { - If all fingerprints of a slap are annotated, an indication that the } \\
\text { slap will be skipped from the capture sequence }\end{array}$ \\
\hline Step 5 & Repeat steps 1-4 for other prints if desired. \\
\hline $\begin{array}{l}\text { Alternate Scenario } \\
\text { Exceptions: }\end{array}$ & NA \\
\hline
\end{tabular}




\subsubsection{UC - Fingerprints.07}

\begin{tabular}{|c|c|}
\hline UC- Fingerprints.07 & Annotate Prints - QCP Application Initiated \\
\hline Actors & HRT member \\
\hline Precondition & QCP application successfully launched \\
\hline Postcondition & Missing prints annotated \\
\hline \multirow{2}{*}{\multicolumn{2}{|c|}{\begin{tabular}{|l|} 
Includes \\
Extends From
\end{tabular}}} \\
\hline & \\
\hline Super Use Case & UC - Fingerprints. 02 or UC - Fingerprints. 03 \\
\hline Trigger & $\begin{array}{l}\text { QCP application detects fingerprint(s) missing from captured slap } \\
\text { print image }\end{array}$ \\
\hline \multicolumn{2}{|l|}{ Description } \\
\hline \multicolumn{2}{|c|}{$\begin{array}{l}\text { During fingerprint capture process, if QCP application detects any missing prints, it will prompt } \\
\text { user to annotate the missing prints. }\end{array}$} \\
\hline \multicolumn{2}{|c|}{ Process Description } \\
\hline $\begin{array}{l}\text { Primary Process } \\
\text { Scenario }\end{array}$ & QCP-initiated Annotation \\
\hline Step 1 & $\begin{array}{l}\text { QCP application presents to the user: } \\
\text { - Indication of number of missing print(s) } \\
\text { - For slap, options to select individual slap component(s) } \\
\text { - Annotation choices for each missing print, choices (no default } \\
\text { should be set) available are: } \\
\quad \circ \text { Unable to print } \\
\quad \text { Amputated }\end{array}$ \\
\hline Step 2 & $\begin{array}{l}\text { User: } \\
\bullet \quad \text { If slap, decides what slap component(s) to annotate } \\
-\quad \text { Selects from annotation choices }\end{array}$ \\
\hline Step 3 & $\begin{array}{l}\text { QCP application presents to the user: } \\
\text { - Indication of annotation for the annotated print or slap } \\
\text { - If the capture sequence includes any finger prints corresponding } \\
\text { to annotated slap components, } \\
\circ \text { indication of annotation for the annotated fingerprints } \\
\circ \quad \text { indication that the fingerprints will be skipped }\end{array}$ \\
\hline $\begin{array}{l}\text { Exceptions, Error } \\
\text { Situations: }\end{array}$ & $\begin{array}{l}\text { - Exception: QCP application shall not allow user to annotate } \\
\text { more than the missing prints. }\end{array}$ \\
\hline
\end{tabular}


Open Issues/Notes

For annotating individual fingers, user will have to initiate the annotation.

\subsubsection{UC - Fingerprints. 08}

\begin{tabular}{|c|c|}
\hline UC- Fingerprints.08 & Modify/Remove Annotation \\
\hline Actors & HRT member \\
\hline Precondition & QCP application successfully launched \\
\hline Postcondition & Annotation(s) successfully modified or removed \\
\hline \multirow{2}{*}{\multicolumn{2}{|c|}{\begin{tabular}{|l|} 
Includes \\
Extends From
\end{tabular}}} \\
\hline & \\
\hline Super Use Case & Alternate scenario in UC - Fingerprints. 02 or UC - Fingerprints. 03 \\
\hline Trigger & User decides to modify/remove annotation. \\
\hline \multicolumn{2}{|l|}{ Description } \\
\hline \multicolumn{2}{|c|}{$\begin{array}{l}\text { During fingerprint capture process, for any previously annotated prints, user can choose to } \\
\text { modify or remove the annotations. }\end{array}$} \\
\hline \multicolumn{2}{|c|}{ Process Description } \\
\hline $\begin{array}{l}\text { Primary Process } \\
\text { Scenario }\end{array}$ & Modify/Remove Slap Annotation \\
\hline Step 1 & User chooses a slap annotation to modify/remove. \\
\hline Step 2 & $\begin{array}{l}\text { QCP application presents to the user: } \\
\text { - Existing annotation(s) } \\
\text { - Options to select/deselect individual slap component(s) } \\
\text { - Annotation choices for each selected component, choices } \\
\text { available are: } \\
\quad \text { Unable to print } \\
\quad 0 \text { Amputated } \\
\text { - Option to remove existing annotation }\end{array}$ \\
\hline Step 3 & User decides what slap component(s) to modify. \\
\hline Step 4 & $\begin{array}{l}\text { QCP application presents to the user: } \\
\text { - Indication of annotation for the annotated print } \\
\text { - If the capture sequence includes any fingerprints corresponding } \\
\text { to annotated slap components, an indication that the fingerprints } \\
\text { will be skipped } \\
\text { - If all slap components are annotated, an indication that the slap } \\
\text { will be skipped from the capture sequence } \\
\text { - Allow fingerprint capture for any unannotated slap components } \\
\text { - If all slap components are unannotated, an indication that the }\end{array}$ \\
\hline
\end{tabular}




\begin{tabular}{|c|c|}
\hline & slap will be included in the capture sequence \\
\hline Step 5 & Repeat steps $1-4$ for other slap prints if desired. \\
\hline $\begin{array}{l}\text { Exceptions, Error } \\
\text { Situations: }\end{array}$ & NA \\
\hline $\begin{array}{l}\text { Alternate Process } \\
\text { Scenario }\end{array}$ & Modify/Remove Individual Finger Annotation \\
\hline Step 1 & User chooses an individual fingerprint annotation to modify/remove. \\
\hline Step 2 & $\begin{array}{l}\text { QCP application presents to the user: } \\
\text { - Existing annotation } \\
\text { - Option to modify annotation, choices available are: } \\
\circ \text { Unable to print } \\
\circ \text { Amputated } \\
\text { - Option to remove annotation }\end{array}$ \\
\hline Step 3 & User selects an annotation option. \\
\hline Step 4 & $\begin{array}{l}\text { QCP application presents to the user: } \\
\text { - Indication of annotation for the annotated fingerprint } \\
\text { - Indication of annotation for the corresponding slap that includes } \\
\text { the annotated fingerprint } \\
\text { - Indication that the annotated print will be skipped from the } \\
\text { capture sequence } \\
\text { - If all fingerprints of a slap are annotated, an indication that the } \\
\text { slap will be skipped from the capture sequence } \\
\text { - Allow capture for any unannotated fingerprint } \\
\text { - If all slap components are unannotated, an indication that the } \\
\text { - Ilap will be included in the capture sequence. } \\
\text { becomes "unannotated" and the print will be put back onto the } \\
\text { capture sequence. }\end{array}$ \\
\hline Step 5 & Repeat steps 1-4 for other prints if desired. \\
\hline $\begin{array}{l}\text { Alternate Scenario } \\
\text { Exceptions: }\end{array}$ & NA \\
\hline Open Issues/Notes & \\
\hline
\end{tabular}




\subsubsection{Use Case - Photos}

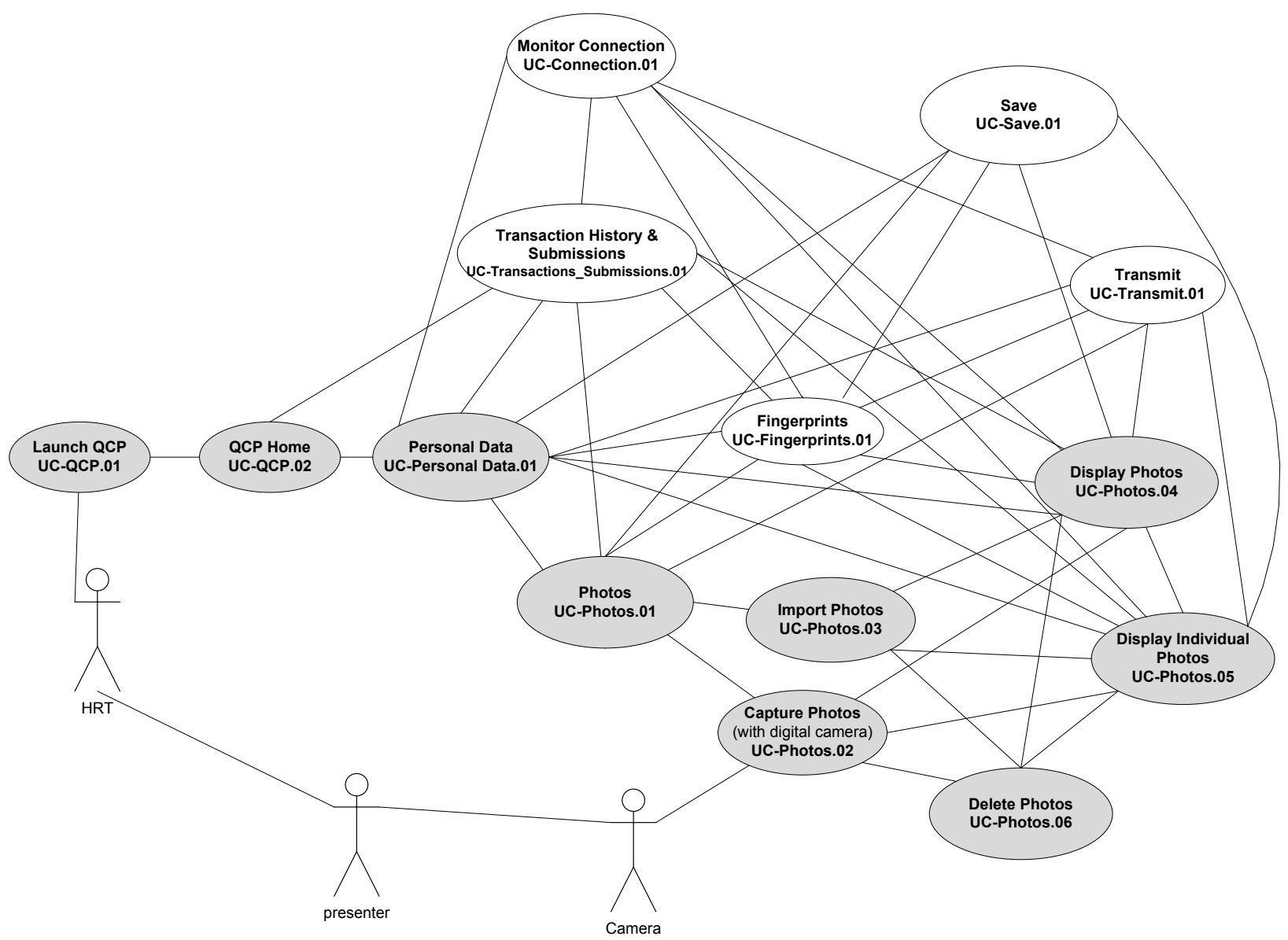

Figure 6 Photos

\subsubsection{UC - Photos.01}

\begin{tabular}{|l|l|}
\hline UC- Photos.01 & Photos \\
\hline Actors & HRT member, presenter, embedded digital camera (optional) \\
\hline Precondition & QCP application successfully launched \\
\hline Postcondition & Photos displayed \\
\hline Includes & UC - Connection.01 \\
\hline Extends From & \\
\hline Super Use Case & \\
\hline Trigger & User decides to access photos feature of the QCP application. \\
\hline Description & \\
\hline
\end{tabular}




\begin{tabular}{|c|c|}
\hline \multirow{2}{*}{\multicolumn{2}{|c|}{$\begin{array}{l}\text { The Photos area provides } \\
\text { embedded digital camera } \\
\text { Process Description }\end{array}$}} \\
\hline & \\
\hline $\begin{array}{l}\text { Primary Process } \\
\text { Scenario }\end{array}$ & New Photos \\
\hline Step 1 & 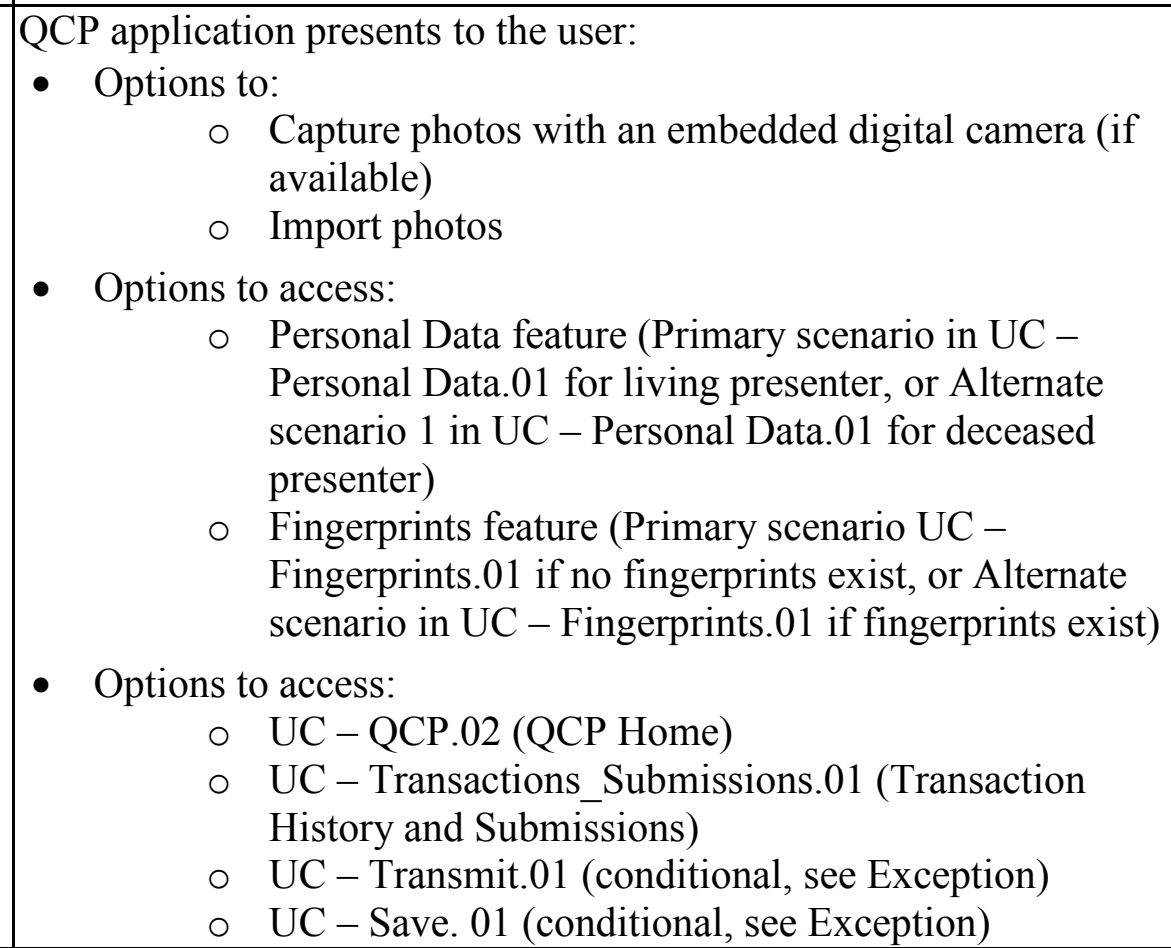 \\
\hline Step 2 & $\begin{array}{l}\text { - UC-Photos.02 if user selects capture photos with camera } \\
\text { option in Step } 1 \text {. } \\
\text { - } U C-\text { Photos.03 if user selects import photos option in Step } 1 .\end{array}$ \\
\hline $\begin{array}{l}\text { Exceptions, Error } \\
\text { Situations: }\end{array}$ & $\begin{array}{l}\text { - Exception: "Transmit" will only be available - } \\
\text { O when all mandatory data (including personal data, and } \\
\text { fingerprints) are completed } \\
\text { ○ HRT Submission/Response software is available } \\
\text { - Exception: "Save" will only be available - } \\
\circ \quad \begin{array}{l}\text { when there are changes made since data was last } \\
\text { saved }\end{array}\end{array}$ \\
\hline $\begin{array}{l}\text { Alternate Process } \\
\text { Scenario }\end{array}$ & Existing Photos \\
\hline Step 1 & UC-Photos.04 (Display Photos) \\
\hline
\end{tabular}


Open Issues/Notes

\subsubsection{UC - Photos.02}

\begin{tabular}{|c|c|}
\hline UC- Photos.02 & Capture Photos with an Embedded Digital Camera \\
\hline Actors & HRT member, Presenter, Embedded Digital Camera \\
\hline Precondition & The user has chosen the photos feature of QCP application. \\
\hline Postcondition & The photos capturing process is completed. \\
\hline \multirow{2}{*}{\multicolumn{2}{|c|}{\begin{tabular}{|l|} 
Includes \\
Extends From
\end{tabular}}} \\
\hline & \\
\hline Super Use Case & UC - Photos.01 \\
\hline Trigger & User chooses to capture photos with an embedded digital camera. \\
\hline \multicolumn{2}{|l|}{ Description } \\
\hline \multicolumn{2}{|c|}{ The user may use a digital camera embedded in the QCP hardware to take pictures. } \\
\hline \multicolumn{2}{|c|}{ Process Description } \\
\hline $\begin{array}{l}\text { Primary Process } \\
\text { Scenario }\end{array}$ & Photos capture (camera embedded in the computer) \\
\hline Step 1 & $\begin{array}{l}\text { QCP application presents to the user: } \\
\text { - Indication of camera readiness } \\
\text { - A display of active view finder } \\
\text { - An area containing indication of temporary pictures taken } \\
\text { - Options to: } \\
\circ \text { Take picture } \\
\circ \text { Display or hide (default) an overlay guide for photo } \\
\text { taking } \\
\circ \text { Delete temporary picture(s) (Primary scenario in UC- } \\
\quad \text { Photos.06) } \\
\circ \text { Determine photo capture process completion } \\
\end{array}$ \\
\hline Step 2 & User points camera toward the presenter, e.g. face, profile, etc. \\
\hline Step 3 & $\begin{array}{l}\text { QCP application displays to the user a preview of the content of the } \\
\text { view finder. }\end{array}$ \\
\hline Step 4 & User takes the picture. \\
\hline Step 5 & $\begin{array}{l}\text { QCP application presents to user: } \\
\begin{array}{l}\text { - Indication of the picture taken in the temporary area } \\
\circ \quad \text { Each picture will be assigned a label by the QCP } \\
\text { application }\end{array}\end{array}$ \\
\hline
\end{tabular}




\begin{tabular}{|l|l|}
\hline Step 6 & $\begin{array}{l}\text { Repeat steps 1to 5 until user determines photos capture process } \\
\text { completion. }\end{array}$ \\
\hline Step 7 & UC-Photos.04 (Display Photos). \\
\hline $\begin{array}{l}\text { Exceptions, Error } \\
\text { Situations: }\end{array}$ & NA \\
\hline Open Issues/Notes \\
\hline
\end{tabular}

\subsubsection{UC - Photos.03}

\begin{tabular}{|c|c|}
\hline UC-Photos.03 & Import Photos \\
\hline Actors & HRT member \\
\hline Precondition & The user has chosen the photos feature of QCP application. \\
\hline Postcondition & The photos importing process is completed. \\
\hline \multirow{2}{*}{\multicolumn{2}{|c|}{\begin{tabular}{|l|} 
Includes \\
Extends From \\
\end{tabular}}} \\
\hline & Extends From \\
\hline Super Use Case & UC - Photos.01 \\
\hline Trigger & User chooses to import photos. \\
\hline \multicolumn{2}{|l|}{ Description } \\
\hline \multicolumn{2}{|c|}{ The user can import photos from sources outside of the QCP application. } \\
\hline \multicolumn{2}{|c|}{ Process Description } \\
\hline $\begin{array}{l}\text { Primary Process } \\
\text { Scenario }\end{array}$ & Import Photos \\
\hline Step 1 & $\begin{array}{l}\text { QCP application presents to the user: } \\
\text { - A way to browse and locate the photo(s) } \\
\text { - Indication of supported file format(s) }\end{array}$ \\
\hline Step 2 & User locates and selects photo(s) of interest. \\
\hline Step 3 & User decides to import the photos. \\
\hline Step 4 & UC-Photos.04 (Display Photos). \\
\hline $\begin{array}{l}\text { Exceptions, Error } \\
\text { Situations: }\end{array}$ & NA \\
\hline Open Issues/Notes & \\
\hline
\end{tabular}




\subsubsection{UC - Photos.04}

\begin{tabular}{|c|c|}
\hline UC- Photos.04 & Display Photos \\
\hline Actors & HRT member \\
\hline Precondition & The user has chosen the photos feature of QCP application. \\
\hline Postcondition & The photos are displayed. \\
\hline Includes & $\mathrm{UC}-$ Connection. 01 \\
\hline \multicolumn{2}{|l|}{ Extends From } \\
\hline Super Use Case & UC - Photos.01 \\
\hline Trigger & $\begin{array}{l}\text { - Photos captured with embedded camera (UC-Photos.02) } \\
\text {-OR- } \\
\text { - Photos imported (UC-Photos.03) }\end{array}$ \\
\hline \multicolumn{2}{|l|}{ Description } \\
\hline \multicolumn{2}{|c|}{$\begin{array}{l}\text { The QCP application displays an area that may contain any photos taken from an embedded } \\
\text { camera or imported photos. }\end{array}$} \\
\hline \multicolumn{2}{|c|}{ Process Description } \\
\hline $\begin{array}{l}\text { Primary Process } \\
\text { Scenario }\end{array}$ & Display Photos from capture or import \\
\hline Step 1 & $\begin{array}{l}\text { QCP application presents to the user: } \\
\text { - Photos captured or imported, with names: } \\
\text { ○ Photo labels (if captured) } \\
\text {-OR- } \\
\circ \text { File names (if imported) } \\
\text { - Photos are displayed in the order in which they were taken by } \\
\text { the embedded camera or imported from files } \\
\text { - Option to indicate whether all photos will be included for } \\
\text { transmission with the default as not included (conditional, see } \\
\text { Exception) } \\
\text { - Options to: } \\
\circ \text { View individual photos } \\
\circ \text { Select photo(s) to delete (Alternate scenario } 1 \text { in UC- } \\
\text { Photos.06) } \\
\circ \text { Change photo names } \\
\text { - Options to: } \\
\text { Capture photos with a embedded digital camera (if } \\
\text { available) (UC - Photos.02) } \\
\text { - Import photos (UC - Photos.03) } \\
\text { Options to access: }\end{array}$ \\
\hline
\end{tabular}




\begin{tabular}{|c|c|}
\hline & 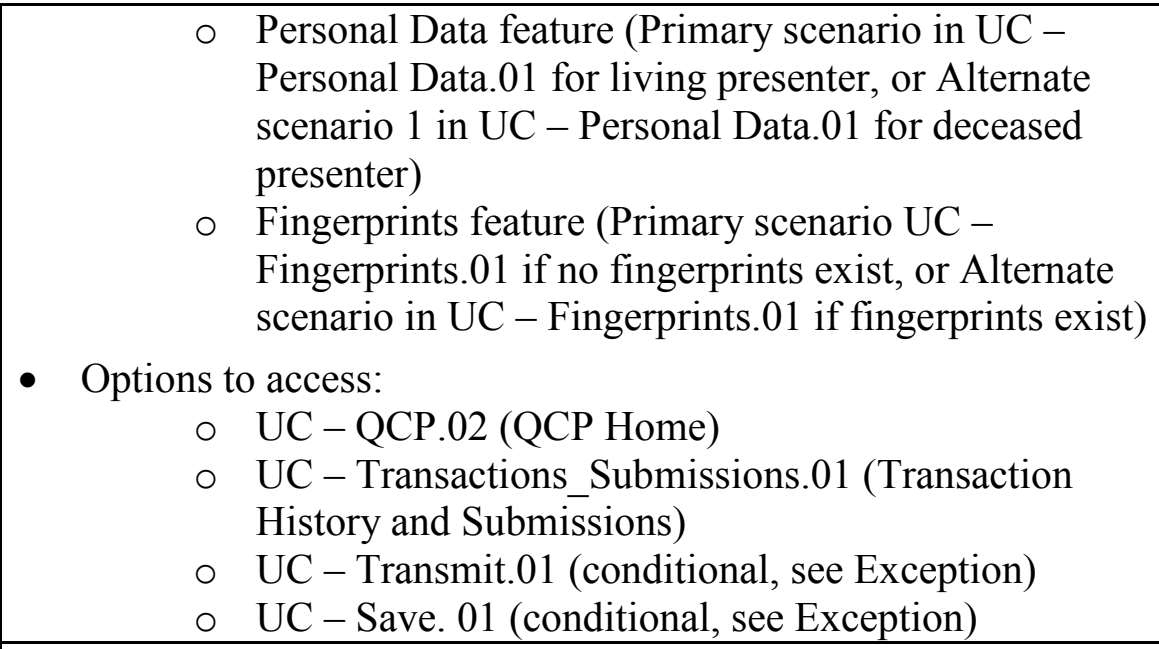 \\
\hline Step 2 & UC-Photos. 05 if user chooses to view individual photos. \\
\hline $\begin{array}{l}\text { Exceptions, Error } \\
\text { Situations: }\end{array}$ & $\begin{array}{l}\text { - Exception: "Transmit" will only be available - } \\
\circ \text { when all mandatory data (including personal data, and } \\
\text { fingerprints) are completed } \\
\circ \text { HRT Submission/Response software is available } \\
\text { - Exception: if user chooses not to include photos for } \\
\text { transmission: } \\
\text { QCP application shall not check for mandatory data } \\
\text { completeness in the Photos area for transmission } \\
\text { - Exception: the option to include photos for transmission will } \\
\text { only be available, if: } \\
\circ \text { Total file (EFT) size does not exceed 1MB } \\
\circ \text { There is at least one photo } \\
\text { - Exception: if user chooses to delete photo(s), QCP application } \\
\text { presents to the user a request to confirm photo deletion. } \\
\text { - Exception: "Save" will only be available - } \\
\circ \text { when there are changes made since data was last } \\
\text { saved }\end{array}$ \\
\hline $\begin{array}{l}\text { Alternate Process } \\
\text { Scenario }\end{array}$ & View only display photos for a transmitted transaction \\
\hline Step 1 & $\begin{array}{l}\text { QCP application presents to the user: } \\
\text { - Photos, with names, in the transaction } \\
\text { - Photos are displayed in the order in which they were taken by } \\
\text { the embedded camera or imported from files }\end{array}$ \\
\hline
\end{tabular}




\begin{tabular}{|c|c|}
\hline & $\begin{array}{l}\text { - Option to view individual photos } \\
\text { - Options to access: } \\
\circ \text { Personal Data feature (Alternate scenario } 3 \text { in UC- } \\
\text { Personal Data.01) } \\
\circ \text { Fingerprints feature (Alternate scenario } 1 \text { in UC - } \\
\text { Fingerprints.04) } \\
\circ \text { View RAP sheet for a "Hit" response (Alternate } \\
\text { scenario } 2 \text { UC - Transaction.04) } \\
\text { - Options to access: } \\
\circ \text { UC - QCP.02 (QCP Home) } \\
\circ \text { UC - Transactions_Submissions.01 (Transaction } \\
\text { History and Submissions) } \\
\text { - Option to Update the transaction (UC - Transaction.03) }\end{array}$ \\
\hline Step 2 & UC - Photos. 05 if user chooses to view individual photos. \\
\hline $\begin{array}{l}\text { Alternate Scenario } \\
\text { Exceptions: }\end{array}$ & Same as in primary scenario. \\
\hline
\end{tabular}

\subsubsection{UC - Photos.05}

\begin{tabular}{|l|l|}
\hline UC- Photos.05 & Display Individual Photos \\
\hline Actors & HRT member \\
\hline Precondition & Successful UC - Photos.04 \\
\hline Postcondition & A single photo displayed \\
\hline Includes & UC - Connection.01 \\
\hline Extends From & UC - Photos.04 \\
\hline Super Use Case & \\
\hline Trigger & User decides to view an individual photo. \\
\hline Description & \\
\hline $\begin{array}{l}\text { The QCP application displays a single photo with options to view the photo in different sizes } \\
\text { and navigate to other photos, if available. }\end{array}$ \\
\hline \begin{tabular}{l} 
Process Description \\
\hline $\begin{array}{l}\text { Primary Process } \\
\text { Scenario }\end{array}$
\end{tabular} & Display of a photo \\
\hline Step 1 & User selects the option to view a photo. \\
\hline
\end{tabular}




\begin{tabular}{|c|c|}
\hline Step 2 & 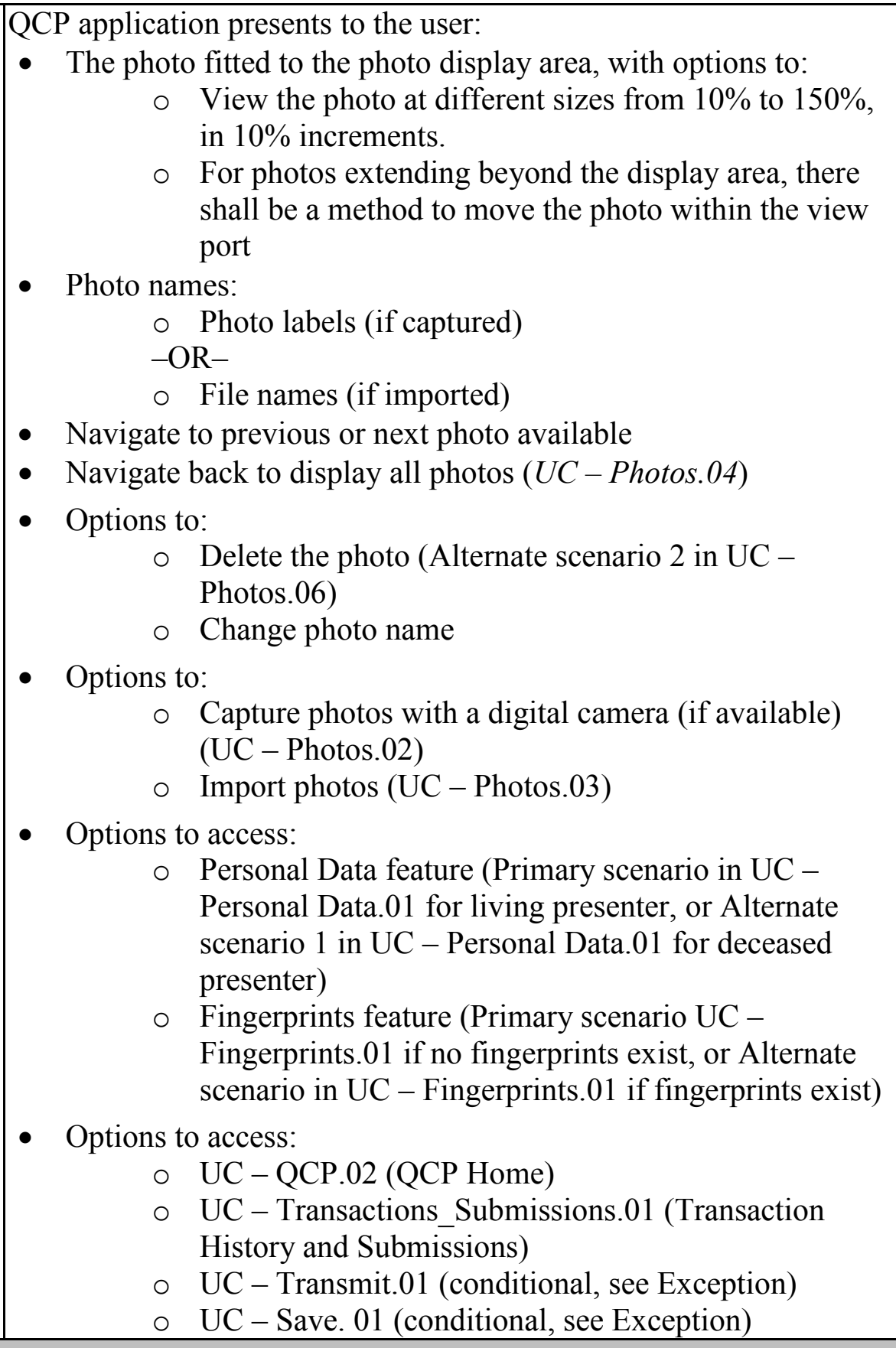 \\
\hline $\begin{array}{l}\text { Exceptions, Error } \\
\text { Situations: }\end{array}$ & $\begin{array}{l}\text { - Exception: if user chooses to delete a photo, QCP application } \\
\text { presents to the user a request to confirm photo deletion. } \\
\text { - Exception: "Transmit" will only be available - } \\
\text { O when all mandatory data (including personal data, and }\end{array}$ \\
\hline
\end{tabular}




\begin{tabular}{|c|c|}
\hline & $\begin{array}{l}\text { fingerprints) are completed } \\
\text { ○ HRT Submission/Response software is available } \\
\text { - Exception: the option to include photos for transmission will } \\
\text { only be available, if total file (EFT) size does not exceed 1MB } \\
\text { - Exception: "Save" will only be available - } \\
\text { o when there are changes made since data was last } \\
\text { saved }\end{array}$ \\
\hline $\begin{array}{l}\text { Alternate Process } \\
\text { Scenario }\end{array}$ & Display of a photo for a transmitted transaction \\
\hline Step 1 & User selects the option to view an enlarged photo. \\
\hline Step 2 & 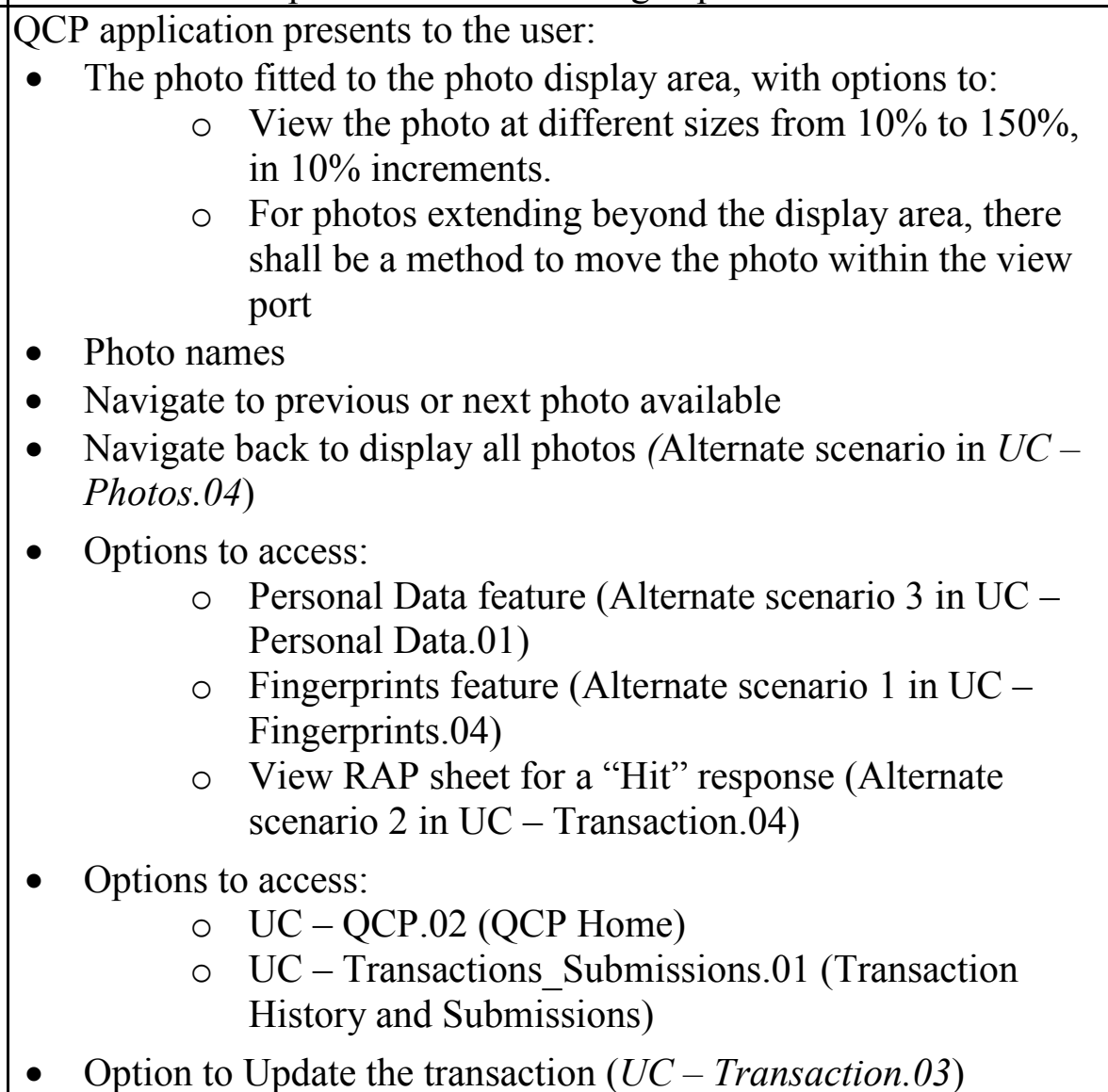 \\
\hline \multicolumn{2}{|l|}{ Open Issues/Notes } \\
\hline
\end{tabular}




\subsubsection{UC - Photos.06}

\begin{tabular}{|c|c|}
\hline UC- Photos.06 & Delete Photos \\
\hline Actors & HRT member \\
\hline Precondition & At least one photo available \\
\hline Postcondition & Photo(s) deleted successfully \\
\hline \multirow{2}{*}{\multicolumn{2}{|c|}{\begin{tabular}{|l|} 
Includes \\
Extends From
\end{tabular}}} \\
\hline & \\
\hline \multicolumn{2}{|l|}{ Super Use Case } \\
\hline Trigger & $\begin{array}{l}\text { User decides to delete photo(s) from: } \\
\text { - UC - Photos.02 (Capture photos with an embedded digital } \\
\text { camera) } \\
\text {-OR- } \\
\text { - Primary scenario in UC - Photos.04 (Display photos) } \\
\text {-OR- } \\
\text { - Primary scenario in UC - Photos.05 (Display individual photos) }\end{array}$ \\
\hline \multicolumn{2}{|l|}{ Description } \\
\hline \multicolumn{2}{|c|}{ The user chooses and removes photo(s) from the QCP application. } \\
\hline \multicolumn{2}{|c|}{ Process Description } \\
\hline $\begin{array}{l}\text { Primary Process } \\
\text { Scenario }\end{array}$ & Delete Photo(s) while taking pictures \\
\hline Step 1 & User selects temporary picture(s) for deletion. \\
\hline Step 2 & $\begin{array}{l}\text { QCP application presents to the user: } \\
\text { - Indication of selected picture(s) }\end{array}$ \\
\hline Step 3 & - User decides to delete the selected picture(s). \\
\hline $\begin{array}{l}\text { Exceptions, Error } \\
\text { Situations: }\end{array}$ & $\begin{array}{l}\text { - Exception: QCP application shall not request confirmation of } \\
\text { deleting temporary pictures. }\end{array}$ \\
\hline $\begin{array}{l}\text { Alternate Process } \\
\text { Scenario } 1\end{array}$ & Delete Photo(s) in Display Photos area \\
\hline Step 1 & User selects photo(s) for deletion. \\
\hline Step 2 & $\begin{array}{l}\text { QCP application presents to the user: } \\
\text { - Indication of selected photo (s) }\end{array}$ \\
\hline Step 3 & User decides to delete the selected photo (s). \\
\hline Step 4 & $\begin{array}{l}\text { QCP application presents to the user: } \\
\text { - A request to confirm the deletion }\end{array}$ \\
\hline Step 5 & User confirms the deletion. \\
\hline
\end{tabular}




\begin{tabular}{|c|c|}
\hline Step 6 & QCP application removes the photos from the display photo area. \\
\hline $\begin{array}{l}\text { Alternate Process } \\
\text { Scenario } 2\end{array}$ & Delete a Photo in Display Individual Photo area \\
\hline Step 1 & User decides to delete the photo. \\
\hline Step 2 & $\begin{array}{l}\text { QCP application presents to the user: } \\
\text { - A request to confirm the deletion }\end{array}$ \\
\hline Step 3 & User confirms the deletion. \\
\hline Step 4 & $\begin{array}{l}\text { QCP application: } \\
\text { - Removes the photo from the display individual photos area. } \\
\text { - Displays the next available photo. }\end{array}$ \\
\hline $\begin{array}{l}\text { Alternate Scenario } \\
\text { Exceptions: }\end{array}$ & $\begin{array}{l}\text { Exception: if there is no more photo available, QCP application } \\
\text { shall take user back to the Display Photo Area (Primary scenario } \\
\text { in UC-Photos.01) }\end{array}$ \\
\hline Open Issues/Notes & \\
\hline
\end{tabular}




\subsection{6 - Use Case - Transaction History and Submissions}

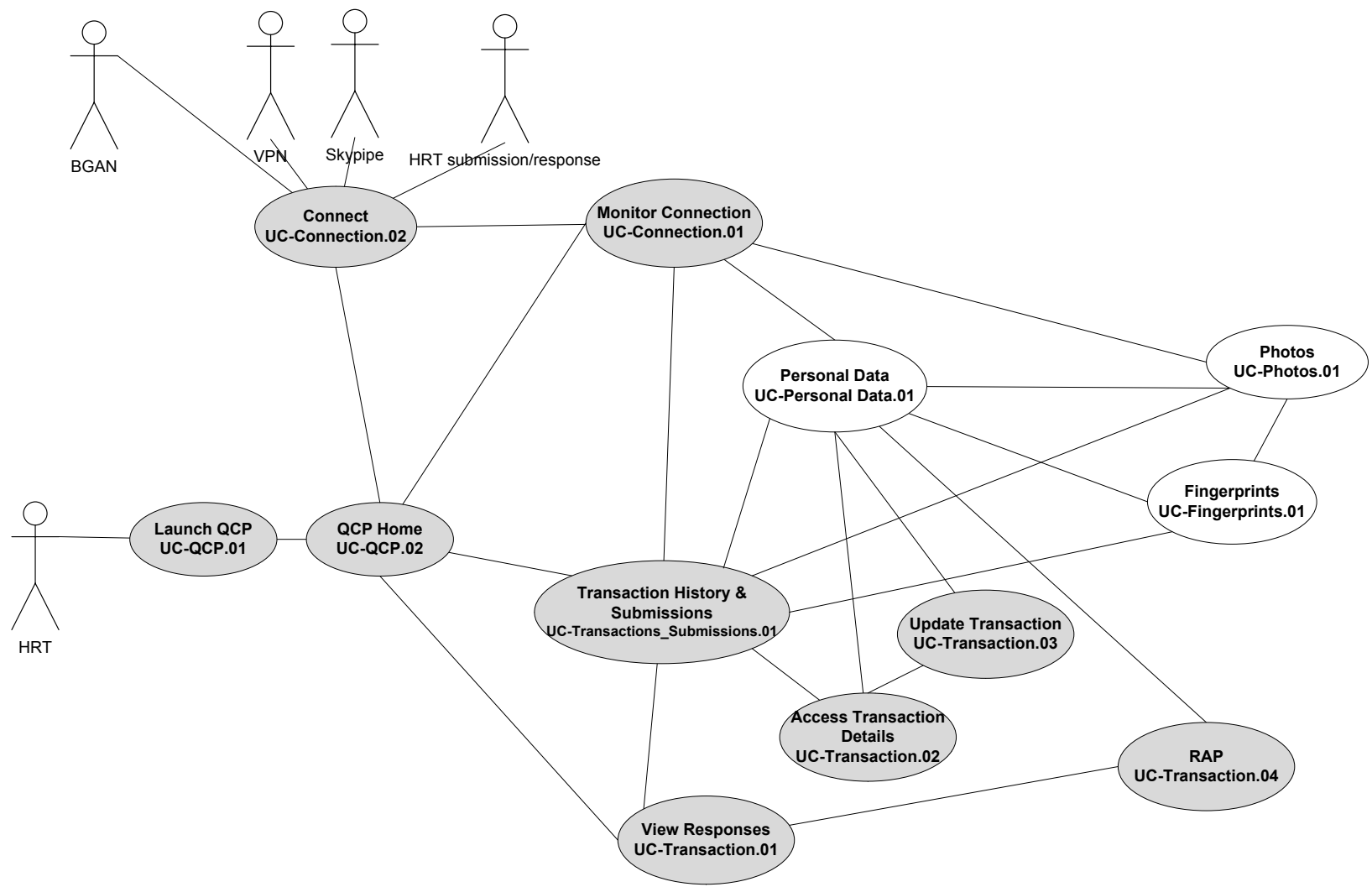

Figure 7 Transactions and Submissions

\subsubsection{UC - Transactions_Submissions.01}

\begin{tabular}{|l|l|}
\hline $\begin{array}{l}\text { UC - Transactions_- } \\
\text { Submissions.01 }\end{array}$ & Display Transaction History and Submissions \\
\hline Actors & HRT member \\
\hline Precondition & QCP application successfully launched \\
\hline Postcondition & Transaction history and submissions displayed \\
\hline Includes & UC - Connection.01 \\
\hline Extends From & \\
\hline Super Use Case & UC - QCP.01 \\
\hline Trigger & $\begin{array}{l}\text { User decides to access transaction history and submissions feature of } \\
\text { the QCP application }\end{array}$ \\
\hline
\end{tabular}




\section{Description}

The QCP application will display any transactions that are saved and transmitted. The ability to sort and search the transactions will be available.

Note: Transactions created in operational mode and training mode will not be displayed concurrently.

\begin{tabular}{|c|c|}
\hline \multicolumn{2}{|c|}{ Process Description } \\
\hline $\begin{array}{l}\text { Primary Process } \\
\text { Scenario }\end{array}$ & Transaction History and Submissions \\
\hline Step 1 & $\begin{array}{l}\text { QCP application presents to the user: } \\
\text { - All transactions created (see Exception). } \\
\circ \text { Each transaction shall have the same set of attributes } \\
\text { (see Appendix B for a list of attributes) } \\
\circ \text { A transaction does not have to have a value for all } \\
\text { attributes } \\
\circ \text { There shall be a user-configurable default set of } \\
\text { attributes for display } \\
\text { - Indication of transaction status, possible statuses are: } \\
\circ \text { Saved } \\
\circ \text { Transmitted, i.e. put into a queue for submitting to } \\
\text { databases } \\
\circ \text { Pending, i.e. submitted to databases awaiting } \\
\text { responses } \\
\circ \text { Responded (with indication of number of responses) } \\
\text { - New transaction statuses from any system initiated status } \\
\text { change, e.g. from "pending" to "responded". } \\
\circ \text { For updated transactions: } \\
\circ \text { Always display the original transaction submitted } \\
\text { Group and display updated transactions with the } \\
\text { original transaction, based on the chronological order } \\
\text { of the updates starting with the oldest } \\
\circ \text { Option to display/hide updated transactions } \\
\text { - Determine the presentation order of the display } \\
\text { - attributes } \\
\text { - There shall be a default attribute } \\
\circ \text { Sort display transactions based on any one attribute } \\
\text { - There shall be a default transaction display } \\
\text { order }\end{array}$ \\
\hline
\end{tabular}




\begin{tabular}{|c|c|}
\hline & \begin{tabular}{|l} 
- \\
- $\begin{array}{l}\text { There shall be a default presentation area } \\
\text { size for each display attribute }\end{array}$ \\
Options to \\
$\circ$ Search the transaction history \\
$\circ$ Import transactions \\
$\circ$ UC - QCP.02 (QCP Home) \\
\end{tabular} \\
\hline Step 2 & $\begin{array}{l}\text { QCP application presents to the user for the transaction of interest: } \\
\text { - Options to } \\
\circ \text { View responses to the transaction with a status as } \\
\text { submitted or responded } \\
\circ \text { Access the details of the transaction }\end{array}$ \\
\hline Step 3 & $\begin{array}{l}\text { - UC-Transaction.01 if user selects View transaction responses } \\
\text { option in step } 2 \\
\text { - UC-Transaction.02 if user selects access details option in step } \\
2\end{array}$ \\
\hline $\begin{array}{l}\text { Exceptions, Error } \\
\text { Situations: }\end{array}$ & $\begin{array}{l}\text { - Exception: any system initiated status changes (e.g. new } \\
\text { response(s) to submission(s)) to the transaction history: } \\
\circ \text { QCP application shall preserve any user selection(s) } \\
\circ \text { QCP application shall not change position of the view } \\
\text { port. } \\
\text { - Exception: } \\
\circ \text { Transactions created while in training mode shall only } \\
\text { appear when QCP application is in training mode. } \\
\circ \quad \text { Transactions created while in operational mode shall } \\
\text { only appear when QCP application is in operational } \\
\text { mode. } \\
\circ \quad \begin{array}{l}\text { Given the separation of transactions between the } \\
\text { operational and training modes, the delete transaction } \\
\text { function will not be necessary. }\end{array} \\
\text { - Exception on updated transactions: } \\
\circ \quad \text { Sorting will only apply to the original transaction } \\
\circ \quad \begin{array}{l}\text { Sorting shall not change the order of transactions } \\
\text { within a group }\end{array} \\
\end{array}$ \\
\hline $\begin{array}{l}\text { Alternate Process } \\
\text { Scenario } 1\end{array}$ & Search Transaction History and Submissions \\
\hline Step 1 & Same as step 1 in primary scenario. \\
\hline Step 2 & User chooses to search the transaction history. \\
\hline Step 3 & QCP application presents to the user: \\
\hline
\end{tabular}




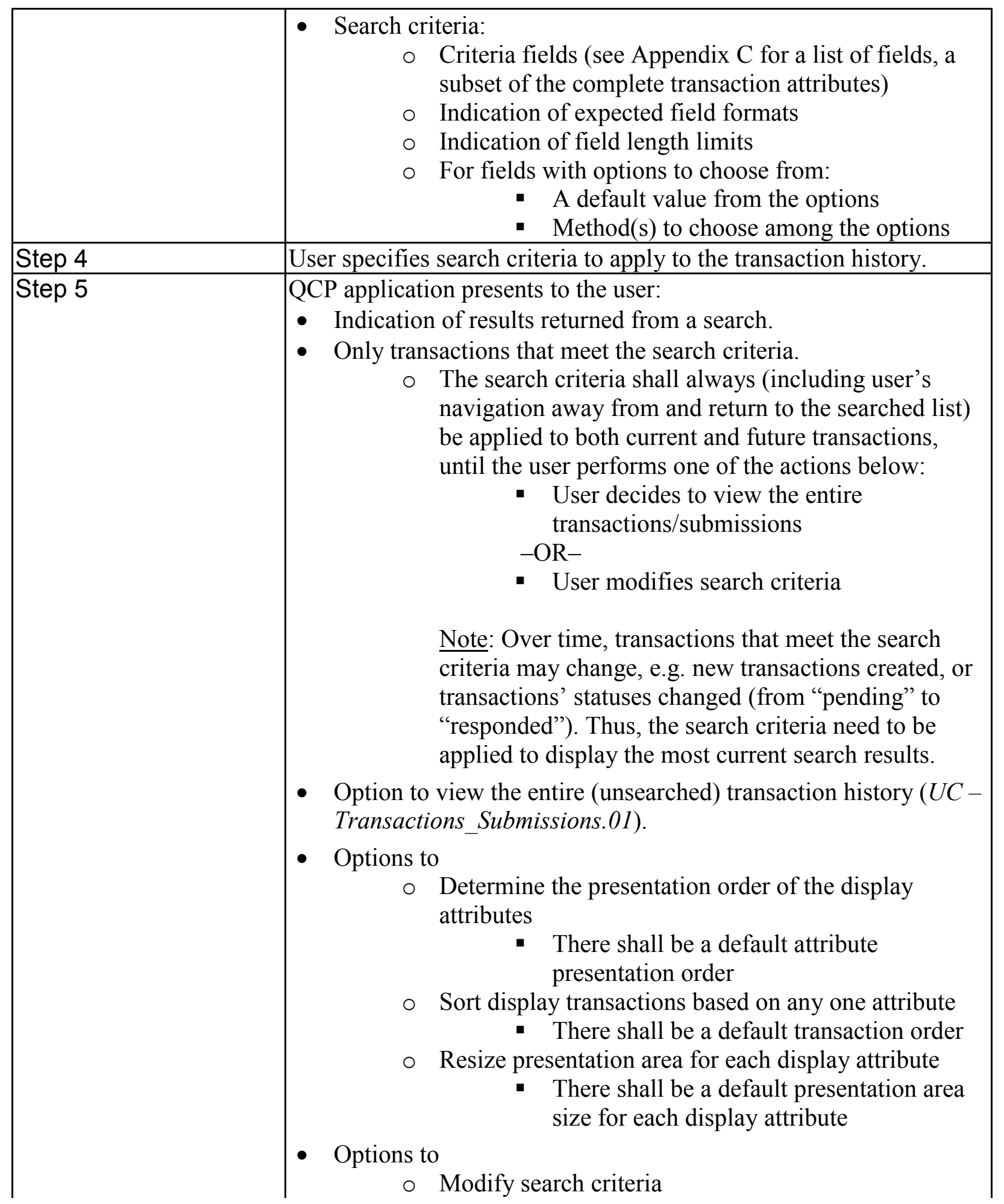




\begin{tabular}{|c|c|}
\hline & \begin{tabular}{|ll} 
& $\mathrm{UC}-\mathrm{QCP} .02(\mathrm{QCP}$ Home$)$ \\
\end{tabular} \\
\hline Step 6 & Same as steps 2 and 3 in primary scenario. \\
\hline $\begin{array}{l}\text { Alternate Scenario } \\
\text { Exceptions: }\end{array}$ & $\begin{array}{l}\text { - Same as primary scenario. } \\
\text { - Exception: if there are no transactions meeting the search } \\
\text { criteria, QCP application shall present an indication that there } \\
\text { are no matching transactions. }\end{array}$ \\
\hline $\begin{array}{l}\text { Alternate Process } \\
\text { Scenario } 2\end{array}$ & Import Transactions \\
\hline Step 1 & Same as step 1 in primary scenario. \\
\hline Step 2 & User decides to import transactions. \\
\hline Step 3 & $\begin{array}{l}\text { QCP application presents to the user a method to browse to the } \\
\text { location of the transactions to be imported. }\end{array}$ \\
\hline Step 4 & User locates and selects transactions to be imported. \\
\hline Step 5 & $\begin{array}{l}\text { QCP application presents to the user an updated } \\
\text { transaction/submission list with the imported transactions added. }\end{array}$ \\
\hline Step 6 & Same as steps 2 and 3 in primary scenario. \\
\hline $\begin{array}{l}\text { Alternate Scenario } \\
\text { Exceptions: }\end{array}$ & Same as primary scenario. \\
\hline Open Issues/Notes & \\
\hline
\end{tabular}

\subsubsection{UC - Transaction. 01}

\begin{tabular}{|l|l|}
\hline UC-Transaction.01 & View Transaction Responses \\
\hline Actors & HRT member \\
\hline Precondition & QCP application successfully launched \\
\hline Postcondition & Transaction responses displayed \\
\hline Includes & \\
\hline Extends From & UC - Transactions_Submissions.01 \\
\hline Super Use Case & $\begin{array}{l}\text { The user decides to view responses to a submitted or responded } \\
\text { transaction. }\end{array}$ \\
\hline Trigger & \\
\hline Description & $\begin{array}{l}\text { The QCP application displays the databases that a transaction has been submitted to, and any } \\
\text { responses from the databases. }\end{array}$ \\
\hline
\end{tabular}




\begin{tabular}{|c|c|}
\hline \multicolumn{2}{|c|}{ Process Description } \\
\hline $\begin{array}{l}\text { Primary Process } \\
\text { Scenario }\end{array}$ & View responses \\
\hline Step 1 & $\begin{array}{l}\text { QCP application presents to the user: } \\
\text { - All databases } \\
\text { - Response status for each database, possible statuses are: } \\
\circ \text { Null (no response yet) } \\
\circ \text { Hit } \\
\circ \text { Rejected } \\
\text { - Date responded } \\
\text { - RAP sheet "Viewed" status } \\
\text { - Options to } \\
\circ \text { View RAP sheet for a "Hit" response } \\
\circ \text { UC - Transactions_Submissions.01 (Transaction } \\
\text { History and Submissions) }\end{array}$ \\
\hline Step 2 & $\begin{array}{l}\text { User selects to view a RAP sheet (Alternate scenario } 1 \text { in } U C- \\
\text { Transaction.04). }\end{array}$ \\
\hline Step 3 & Repeat step 2 for all "Hit" responses, if desired. \\
\hline $\begin{array}{l}\text { Exceptions, ErroI } \\
\text { Situations: }\end{array}$ & \\
\hline Open Issues/Note & \\
\hline
\end{tabular}

\subsubsection{UC - Transaction. 02}

\begin{tabular}{|l|l|}
\hline UC-Transaction.02 & Access Transaction Details \\
\hline Actors & HRT member \\
\hline Precondition & QCP application successfully launched \\
\hline Postcondition & Transaction details displayed \\
\hline Includes & \\
\hline Extends From & \\
\hline Super Use Case & UC - Transactions_Submissions.01 \\
\hline Trigger & The user decides to access the details of a transaction. \\
\hline Description & \\
\hline $\begin{array}{l}\text { The QCP application displays personal data, fingerprints, photos, and RAP sheets if any, for a } \\
\text { transaction. }\end{array}$ \\
\hline Process Description \\
\hline
\end{tabular}




\begin{tabular}{|c|c|}
\hline $\begin{array}{l}\text { Primary Process } \\
\text { Scenario }\end{array}$ & Transmitted Transaction Details \\
\hline Step 1 & $\begin{array}{l}\text { QCP application presents to the user, view only data (non-editable) } \\
\text { - Metadata: } \\
\circ \text { Transaction identifier, e.g. TCN } \\
\circ \text { Type of transaction } \\
\circ \text { Transaction status: } \\
\text { - Transmitted } \\
\text { - Submitted } \\
\text { - Personal Data feature (Alternate scenario } 3 \text { in UC - Personal } \\
\text { Data.01) }\end{array}$ \\
\hline $\begin{array}{l}\text { Exceptions, Error } \\
\text { Situations: }\end{array}$ & $\begin{array}{l}\text { Exception: the "Update" option is only available to a transmitted } \\
\text { transaction. }\end{array}$ \\
\hline $\begin{array}{l}\text { Alternate Process } \\
\text { Scenario }\end{array}$ & Untransmitted Transaction Details \\
\hline Step 1 & $\begin{array}{l}\text { QCP application presents to the user: } \\
\text { - Metadata: } \\
\circ \text { Transaction identifier, e.g. TCN } \\
\circ \text { Type of transaction } \\
\circ \text { Transaction status: } \\
\text { - Untransmitted } \\
\text { - Completion status of each of the areas: personal data, } \\
\text { - Pingerprints, and photos }\end{array}$ \\
\hline Open Issues/Notes & \\
\hline
\end{tabular}

\subsubsection{UC - Transaction.03}

\begin{tabular}{|l|l|}
\hline UC- Transaction.03 & Update Transaction \\
\hline Actors & HRT member \\
\hline Precondition & QCP application successfully launched \\
\hline Postcondition & QCP application displays the updated transaction \\
\hline Includes & \\
\hline Extends From & \\
\hline Super Use Case & UC - Transaction.02 \\
\hline
\end{tabular}




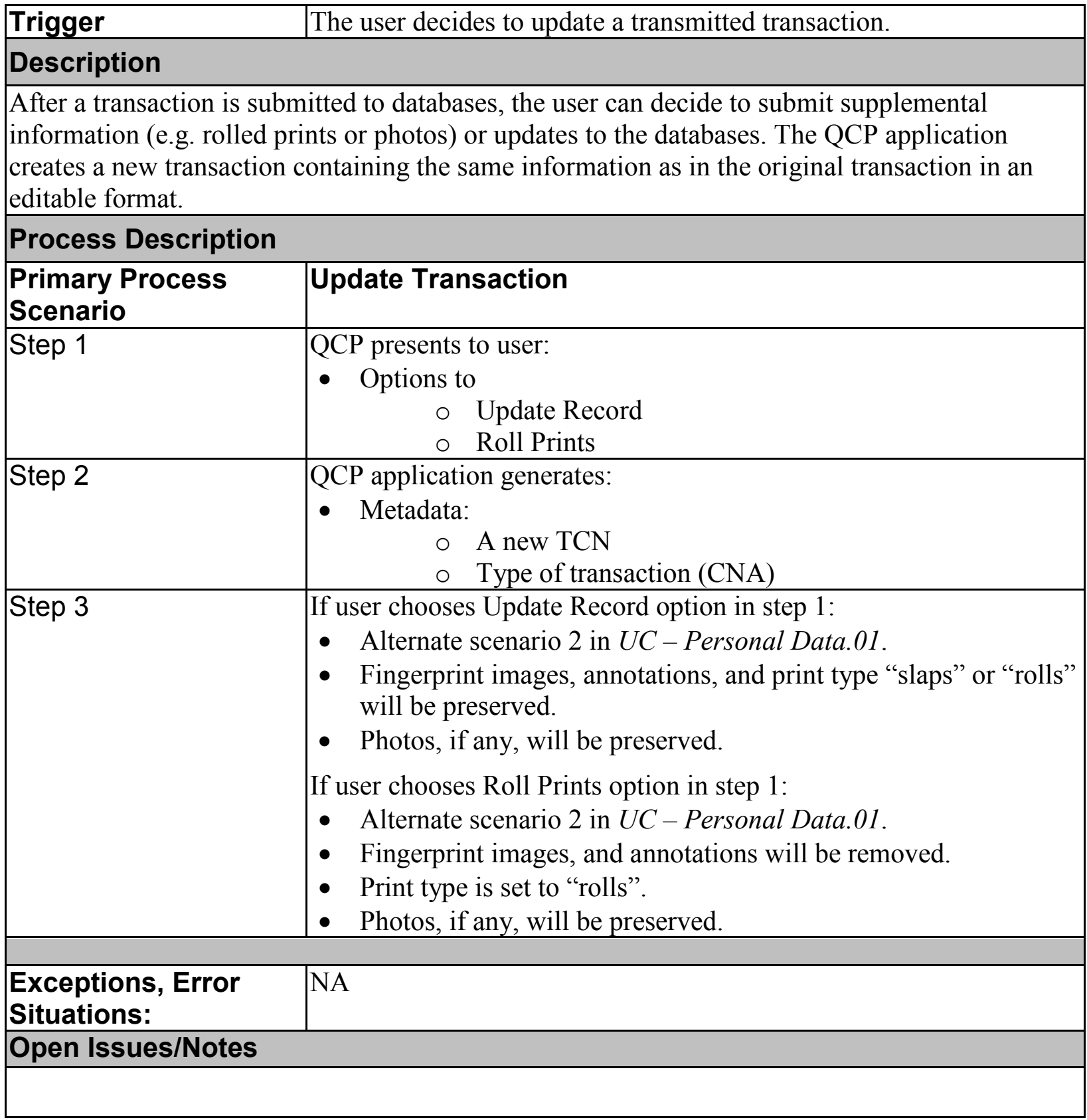

\subsubsection{UC - Transaction.04}

\begin{tabular}{|l|l|}
\hline UC- Transaction.04 & View RAP Sheet \\
\hline Actors & HRT member \\
\hline Precondition & QCP application successfully launched \\
\hline
\end{tabular}




\begin{tabular}{|c|c|}
\hline Postcondition & RAP sheet details displayed \\
\hline \multicolumn{2}{|l|}{ Includes } \\
\hline \multicolumn{2}{|l|}{ Extends From } \\
\hline \multicolumn{2}{|l|}{ Super Use Case } \\
\hline Trigger & $\begin{array}{l}\text { - User chooses to view the RAP sheet from the "Hit" alert notice } \\
(U C-\text { Connection.01). } \\
\text {-OR- } \\
-\quad \text { User chooses to view a RAP sheet while viewing transaction } \\
\text { responses (UC - Transaction.01). } \\
\text {-OR- } \\
-\quad \text { User chooses to view a RAP sheet while viewing transaction } \\
\text { details (UC-Transaction.02). }\end{array}$ \\
\hline \multicolumn{2}{|l|}{ Description } \\
\hline \multicolumn{2}{|c|}{ The QCP application displays the RAP sheets for the transaction with "Hit" response(s). } \\
\hline \multicolumn{2}{|c|}{ Process Description } \\
\hline $\begin{array}{l}\text { Primary Process } \\
\text { Scenario }\end{array}$ & View RAP sheet from "Hit" alert notice \\
\hline Step 1 & $\begin{array}{l}\text { QCP application presents to user: } \\
\text { - Which database the RAP sheet comes from } \\
\text { - The RAP sheet returned in a separate window other than the } \\
\text { main QCP application } \\
\text { - Option to "Copy" the content (full or partial) of the RAP sheet } \\
\text { (conditional, see Exception) } \\
\text { - Option to close the window }\end{array}$ \\
\hline $\begin{array}{l}\text { Exceptions, Error } \\
\text { Situations: }\end{array}$ & $\begin{array}{l}\text { - Exception: "Copy" will only be available when there is text } \\
\text { selected in the RAP sheet content }\end{array}$ \\
\hline $\begin{array}{l}\text { Alternate Process } \\
\text { Scenario } 1\end{array}$ & View RAP sheet while viewing transaction responses \\
\hline Step 1 & $\begin{array}{l}\text { QCP application presents to user: } \\
\text { - Which database the RAP sheet comes from } \\
\text { - The RAP sheet returned } \\
\text { - Option to "Copy" the content (full or partial) of the RAP sheet } \\
\text { (conditional, see Exception) } \\
\text { - Options to: } \\
\circ \quad \text { Navigate to other available RAP sheets for the } \\
\text { transaction } \\
\circ \text { Navigate back to view transaction responses }\end{array}$ \\
\hline
\end{tabular}




\begin{tabular}{|c|c|}
\hline Step 2 & $\begin{array}{l}\text { - Repeat step } 1 \text { if user chooses to view other RAP sheets option } \\
\text { - } U C-\text { Transaction.01 if user chooses back to view transaction } \\
\text { responses option }\end{array}$ \\
\hline $\begin{array}{l}\text { Alternate Scenario } \\
\text { Exceptions: }\end{array}$ & Same as primary scenario. \\
\hline $\begin{array}{l}\text { Alternate Process } \\
\text { Scenario } 2\end{array}$ & View RAP sheet while viewing transaction details \\
\hline Step 1 & $\begin{array}{l}\text { QCP application presents to user: } \\
\text { - Which database the RAP sheet comes from } \\
\text { - } \quad \text { The RAP sheet returned } \\
\text { - } \text { (contion to "Copy" the content (full or partial) of the RAP sheet } \\
\text { - Option to navigate to other available RAP sheets for the } \\
\text { transaction } \\
\text { - Options to access: } \\
\circ \text { Personal Data feature } \\
\circ \text { Fingerprints feature } \\
\circ \text { Photos feature } \\
\text { - Options to } \\
\circ \text { Update the transaction (UC - Transaction.03). } \\
\circ \text { Go to QCP home (UC - QCP.02) } \\
\circ \text { UC - Transactions_Submissions.01 (Transaction } \\
\text { History and Submissions) }\end{array}$ \\
\hline Step 2 & $\begin{array}{l}\text { - Repeat step } 1 \text { if user chooses to view other RAP sheets } \\
\text { - Alternate scenario } 3 \text { in UC-Personal Data.01 if user selects } \\
\text { personal data option in step } 1 \\
\text { - Alternate scenario } 1 \text { in UC-Fingerprints.04 if user selects } \\
\text { fingerprints option in step } 1 \\
\text { - Alternate scenario UC-Photos.04 if user selects photos option } \\
\text { in step 1 }\end{array}$ \\
\hline $\begin{array}{l}\text { Alternate Scenario } \\
\text { Exceptions: } \\
\text { Open Issues/Notes }\end{array}$ & Same as primary scenario. \\
\hline
\end{tabular}




\subsection{7 - Use Case - Transmit}

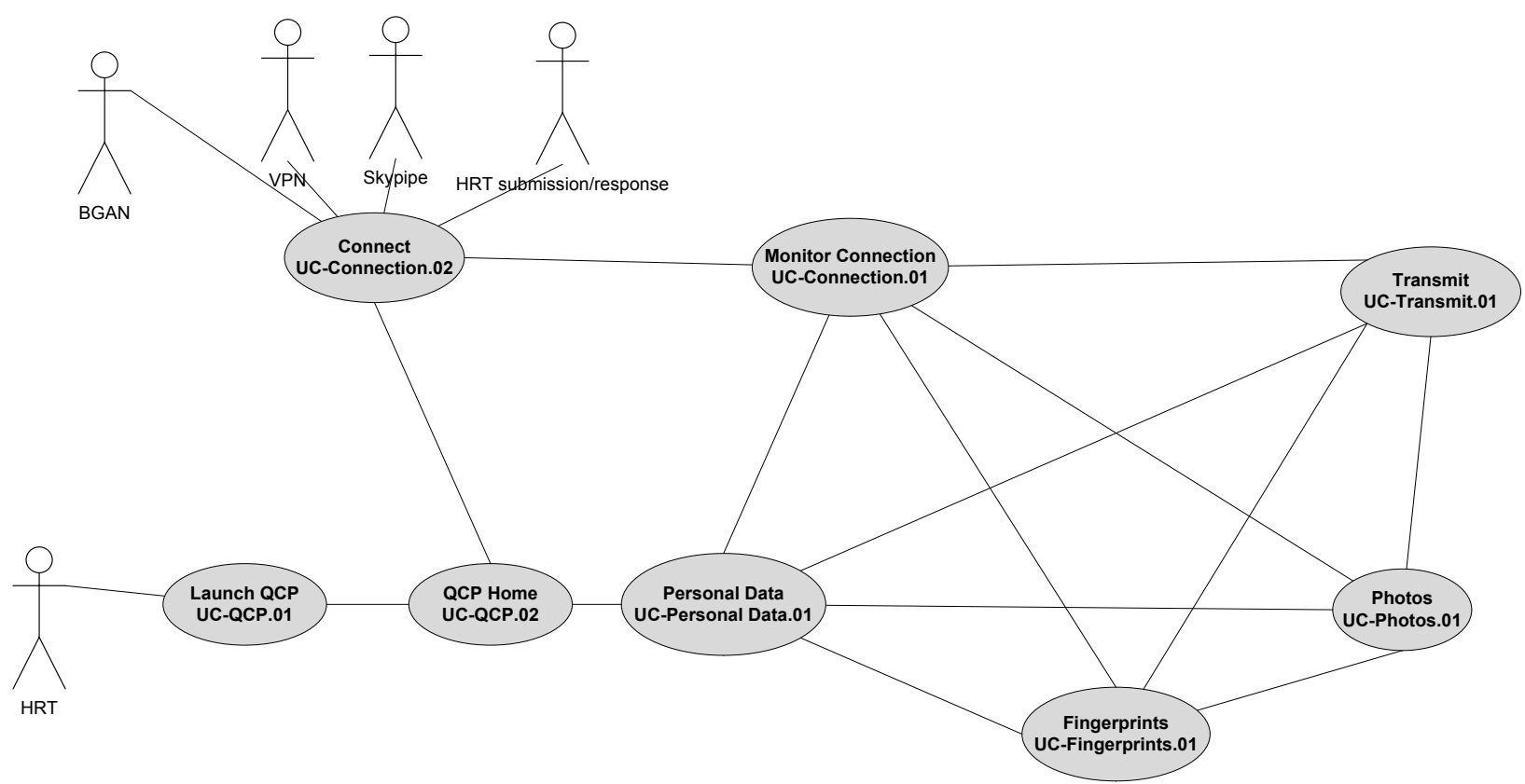

Figure 8 Transmit

\subsubsection{UC - Transmit.01}

\begin{tabular}{|l|l|}
\hline UC- Transmit.01 & Transmit \\
\hline Actors & $\begin{array}{l}\text { HRT member, BGAN, VPN Client, Skypipe, HRT } \\
\text { Submission/Response software }\end{array}$ \\
\hline Precondition & $\begin{array}{l}\text { QCP application successfully launched and all mandatory } \\
\text { information is supplied }\end{array}$ \\
\hline Postcondition & Transaction has been provided for submission to databases \\
\hline Includes & UC - Connection.01 \\
\hline Extends From & \\
\hline Super Use Case & $\begin{array}{l}\text { User chooses the "Transmit" in Primary scenario, Alternate } \\
\text { Trigger }\end{array}$ \\
& $\begin{array}{l}\text { scenario 1 and Alternate scenario 2 from UC - Personal } \\
\text { Data.01. } \\
\\
\text {-OR- }\end{array}$ \\
& $\begin{array}{l}\text { User chooses the "Transmit" in Primary scenario from } U C- \\
\text {-OR- }\end{array}$ \\
\hline
\end{tabular}




\begin{tabular}{|c|c|}
\hline & $\begin{array}{l}\text { - User chooses the "Transmit" in Primary scenario from } U C- \\
\text { Fingerprints. } 05 \text {. } \\
\text {-OR- } \\
\text { - User chooses the "Transmit" in Primary scenario from } U C- \\
\text { Photos. } 01 \text {. } \\
\text {-OR- } \\
\text { - User chooses the "Transmit" in Primary scenario from } U C- \\
\text { Photos. } 04 \text {. } \\
\text {-OR- } \\
\text { - User chooses the "Transmit" in Primary scenario from } U C- \\
\text { Photos. } 05 \text {. }\end{array}$ \\
\hline \multicolumn{2}{|l|}{ Description } \\
\hline \multicolumn{2}{|c|}{$\begin{array}{l}\text { After all mandatory information (Personal Data, Fingerprints) for a transaction has been } \\
\text { supplied, user can transmit the transaction. The QCP application provides the transmitted } \\
\text { transaction for submission. }\end{array}$} \\
\hline \multicolumn{2}{|c|}{ Process Description } \\
\hline $\begin{array}{l}\text { Primary Process } \\
\text { Scenario }\end{array}$ & Transmit a Transaction \\
\hline Step 1 & $\begin{array}{l}\text { QCP application: } \\
\text { - Saves transaction } \\
\text { - Starts transmission } \\
\end{array}$ \\
\hline Step 2 & $\begin{array}{l}\text { QCP application presents to the user: } \\
\text { - Indication that the transaction has been transmitted } \\
\text { - Data (including personal data, fingerprints, and photos) in non- } \\
\text { editable view: } \\
\text { o Alternate scenario } 3 \text { in UC - Personal Data.01 if } \\
\text { "Transmit" is triggered from Personal Data feature } \\
\text { O Alternate scenario } 1 \text { in UC - Fingerprints.04 if } \\
\text { "Transmit" is triggered from Display Fingerprints } \\
\text { feature } \\
\circ \text { Alternate scenario in UC - Fingerprints. } 05 \text { if } \\
\text { "Transmit" is triggered from Display Individual } \\
\text { Fingerprints feature } \\
\circ \text { Alternate scenario in UC - Photos.04 if "Transmit" is } \\
\text { triggered from Display Photos feature } \\
\circ \text { Alternate scenario in UC - Photos.05 if "Transmit" is } \\
\text { triggered from Display Individual Photo feature }\end{array}$ \\
\hline $\begin{array}{l}\text { Exceptions, Error } \\
\text { Situations: }\end{array}$ & NA \\
\hline
\end{tabular}


Open Issues/Notes 


\subsection{8 - Use Case - Save Transaction}

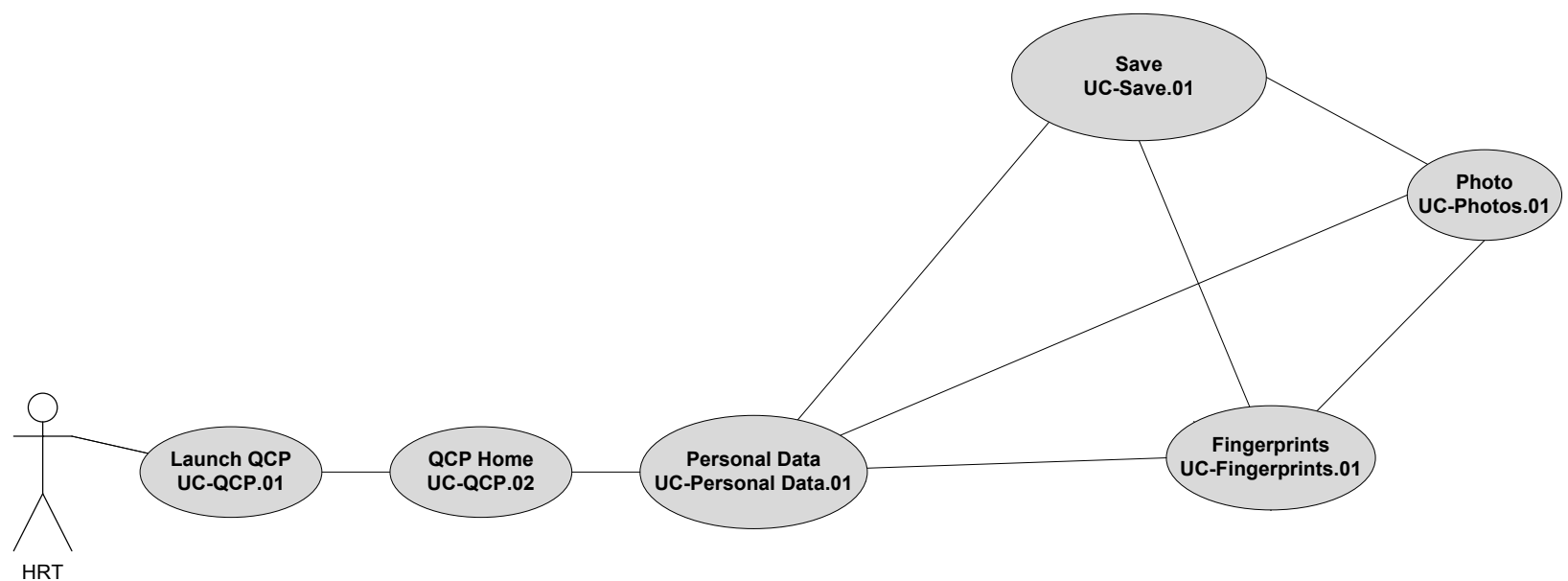

Figure 9 Save Transaction

\subsubsection{UC- Save.01}

\begin{tabular}{|c|c|}
\hline UC- Save.01 & Save Transaction \\
\hline Actors & HRT member \\
\hline Precondition & QCP application successfully launched \\
\hline Postcondition & Transaction saved to the local storage on the QCP hardware \\
\hline \multicolumn{2}{|l|}{ Includes } \\
\hline \multicolumn{2}{|l|}{ Extends From } \\
\hline Super Use Case & \\
\hline Trigger & $\begin{array}{l}\text { - User chooses the Save feature in Primary scenario, Alternate } \\
\text { scenario } 1 \text { and Alternate scenario } 2 \text { from UC-Personal } \\
\text { Data.01. } \\
\text { - OR - } \\
\text { - User chooses the Save feature in Primary scenario from UC- } \\
\text { Fingerprints.04. } \\
\text { - OR - } \\
\text { - User chooses the Save feature in Primary scenario from UC- } \\
\text { Fingerprints.05. } \\
\text { - OR - } \\
\text { - User chooses the Save feature in Primary scenario from } U C- \\
\text { Photos. } 01 \text {. } \\
\text { - UR- } \\
\text { - User chooses the "Transmit" in Primary scenario from } U C-\end{array}$ \\
\hline
\end{tabular}




\begin{tabular}{|c|c|}
\hline & $\begin{array}{l}\text { Photos. } 04 . \\
\text {-OR- } \\
\text { - User chooses the "Transmit" in Primary scenario from } U C- \\
\text { Photos. } 05 .\end{array}$ \\
\hline \multicolumn{2}{|l|}{ Description } \\
\hline \multicolumn{2}{|c|}{$\begin{array}{l}\text { While entering, modifying, or updating information of a transaction, the user can save the } \\
\text { current information of the transaction. }\end{array}$} \\
\hline \multicolumn{2}{|c|}{ Process Description } \\
\hline $\begin{array}{l}\text { Primary Process } \\
\text { Scenario }\end{array}$ & Save current transaction \\
\hline Step 1 & $\begin{array}{l}\text { QCP application presents to user: } \\
\text { - Indication of the activation of the save feature } \\
\text { - Indication of the saving progress }\end{array}$ \\
\hline $\begin{array}{l}\text { Exceptions, Error } \\
\text { Situations: }\end{array}$ & $\begin{array}{l}\text { - Error: QCP fails to save transaction: } \\
\text { O QCP shall presents to the user an error message } \\
\text { indicating the error type, cause of error, and } \\
\text { suggestion for recovery }\end{array}$ \\
\hline $\begin{array}{l}\text { Alternate Scenario } \\
\text { Exceptions: }\end{array}$ & NA \\
\hline Open Issues/Notes & \\
\hline
\end{tabular}




\subsection{9 - Use Case - Training Mode}

\subsubsection{UC - Training.01}

\begin{tabular}{|c|c|}
\hline UC- Training.01 & Training Mode \\
\hline Actors & HRT member \\
\hline Precondition & QCP application successfully launched \\
\hline Postcondition & QCP application is successfully placed in or out of training mode. \\
\hline \\
\hline \multirow{2}{*}{\multicolumn{2}{|c|}{$\begin{array}{l}\text { Extends From } \\
\text { Super Use Case }\end{array}$}} \\
\hline & \\
\hline Trigger & User decides to change the QCP application's training mode. \\
\hline \multicolumn{2}{|l|}{ Description } \\
\hline \multicolumn{2}{|c|}{$\begin{array}{l}\text { The training mode provides the same functionality as in the operational mode. There are two } \\
\text { exceptions: (1) transactions created in training mode will be stored separately from the } \\
\text { transactions created in operational mode; (2) transactions will be submitted to a training } \\
\text { database, such as IAFIS Debug. The training transactions can only be accessed while QCP } \\
\text { application is in training mode. }\end{array}$} \\
\hline \multicolumn{2}{|c|}{ Process Description } \\
\hline \begin{tabular}{|l|} 
Primary Process \\
Scenario \\
\end{tabular} & Training Mode \\
\hline Step 1 & $\begin{array}{l}\text { QCP application presents to the user: } \\
\begin{array}{r}- \text { Indication of training mode status } \\
\circ \quad \text { As long as the training mode is active, an indication } \\
\text { will be presented throughout the QCP application }\end{array}\end{array}$ \\
\hline Step 2 & $U C-Q C P .02(\mathrm{QCP}$ Home $)$ \\
\hline $\begin{array}{l}\text { Exceptions, Error } \\
\text { Situations: }\end{array}$ & NA \\
\hline Open Issues/Notes & \\
\hline
\end{tabular}




\section{APPENDIX A - PERSONAL DATA FIELD ELEMENTS}

Appendix A is intended to provide more detailed requirements regarding personal data fields.

\begin{tabular}{|c|c|c|c|c|c|}
\hline Order & Field Name & $\begin{array}{l}\text { Field } \\
\text { Type }\end{array}$ & Field Format & Values & \begin{tabular}{|l} 
Predicative \\
Text Entry
\end{tabular} \\
\hline 1 & Deceased & Selection & $\mathrm{n} / \mathrm{a}$ & $\begin{array}{l}\text { Yes } \\
\text { No (default) }\end{array}$ & $\mathrm{n} / \mathrm{a}$ \\
\hline 2 & First Name & Text & Alphabetic (max. ??) & $\mathrm{n} / \mathrm{a}$ & Yes \\
\hline 3 & Middle Name & Text & Alphabetic (max. ??) & $\mathrm{n} / \mathrm{a}$ & Yes \\
\hline 4 & Last Name & Text & Alphabetic (max. ??) & $\mathrm{n} / \mathrm{a}$ & Yes \\
\hline 5 & Other Middle/Last & Text & Alphabetic (max. ??) & $\mathrm{n} / \mathrm{a}$ & Yes \\
\hline 6 & Alias & Text & Alphabetic (max. ??) & Multiple & Yes \\
\hline 7 & Hair & Selection & Alphabetic & $\begin{array}{l}\text { Black (default) } \\
\text { ??? }\end{array}$ & $\mathrm{n} / \mathrm{a}$ \\
\hline 8 & Gender & Selection & Alphabetic & $\begin{array}{l}\text { Male (default) } \\
\text { Female } \\
\text { Unknown }\end{array}$ & $\mathrm{n} / \mathrm{a}$ \\
\hline 9 & Date of Birth & Date & yyyymmdd & Multiple & $\mathrm{n} / \mathrm{a}$ \\
\hline 10 & Place of Birth & Selection & Alphabetic & $\begin{array}{l}\text { XX - Unknown (default) } \\
\text { ??? }\end{array}$ & $\mathrm{n} / \mathrm{a}$ \\
\hline 11 & Race & Selection & Alphabetic & $\begin{array}{l}\text { Unknown (default) } \\
\text { Asian } \\
\text { Black } \\
\text { Native American } \\
\text { Caucasian } \\
\text { Latino } \\
\end{array}$ & $\mathrm{n} / \mathrm{a}$ \\
\hline 12 & Eyes & Selection & Alphabetic & $\begin{array}{l}\text { Brown (default) } \\
\text { ??? }\end{array}$ & $\mathrm{n} / \mathrm{a}$ \\
\hline 13 & Height- feet & Selection & Numeric & 0 (default) & $\mathrm{n} / \mathrm{a}$ \\
\hline 14 & Height- inches & Selection & Numeric & 00 (default) & $\mathrm{n} / \mathrm{a}$ \\
\hline 15 & Weight & Text & Numeric & 000 & Yes \\
\hline 16 & Save Info & Selection & Alphabetic & $\begin{array}{l}\text { Yes } \\
\text { No (default) }\end{array}$ & $\mathrm{n} / \mathrm{a}$ \\
\hline 17 & City/Province & Text & Alphanumeric & $\mathrm{n} / \mathrm{a}$ & Yes \\
\hline 18 & State/Country & Text & Alphanumeric & $\mathrm{n} / \mathrm{a}$ & Yes \\
\hline 19 & Remarks & Text & Alphanumeric & $\mathrm{n} / \mathrm{a}$ & $\mathrm{n} / \mathrm{a}$ \\
\hline 20 & Agency & Text & Alphanumeric & $\mathrm{n} / \mathrm{a}$ & Yes \\
\hline 21 & Division & Text & Alphanumeric & $\mathrm{n} / \mathrm{a}$ & Yes \\
\hline 22 & Credential \# & Text & Alphanumeric & $\mathrm{n} / \mathrm{a}$ & Yes \\
\hline 23 & Date of Contact & Date & yyyymmdd & Current date (default) & $\mathrm{n} / \mathrm{a}$ \\
\hline 24 & Type of Search Request & Selection & Alphabetic & $\begin{array}{l}\text { Confidential Search } \\
\text { (default) }\end{array}$ & $\mathrm{n} / \mathrm{a}$ \\
\hline
\end{tabular}




\section{APPENDIX B - ATTRIBUTES IN TRANSACTION HISTORY AND SUBMISSIONS}

Appendix B is intended to provide more detailed requirements regarding transaction attributes in the Transaction History and Submissions. The current system used by the HRT has separate areas for History and Submissions. This design consolidates these two areas into one. The following table provides a tracing of attributes to their origins.

\begin{tabular}{|c|c|c|c|c|c|}
\hline Attribute Name & $\begin{array}{l}\text { Default } \\
\text { Display }\end{array}$ & Attribute Type & Display Size & Possible Values & Origin \\
\hline TCN & Yes & & & $\mathrm{n} / \mathrm{a}$ & $\begin{array}{l}\text { History } \\
\text { Submissions }\end{array}$ \\
\hline Responses & Yes & & & $\mathrm{n} / \mathrm{a}$ & Submissions \\
\hline Status & Yes & & & $\begin{array}{l}\text { Saved } \\
\text { Transmitted } \\
\text { Submitted } \\
\text { Responded (Hit or } \\
\text { Rejected) }\end{array}$ & $\begin{array}{l}\text { (new } \\
\text { requirement) }\end{array}$ \\
\hline Last Name & Yes & & & $\mathrm{n} / \mathrm{a}$ & $\begin{array}{l}\text { History } \\
\text { Submissions }\end{array}$ \\
\hline First Name & Yes & & & n/a & $\begin{array}{l}\text { History } \\
\text { Submissions }\end{array}$ \\
\hline Middle Name & Yes & & & $\mathrm{n} / \mathrm{a}$ & $\begin{array}{l}\text { History } \\
\text { Submissions }\end{array}$ \\
\hline Date of Birth & Yes & Date & & $\mathrm{n} / \mathrm{a}$ & History \\
\hline Primary TCN & & & & & History \\
\hline $\begin{array}{l}\text { Date Transmitted } \\
\text { (Date Submitted) }\end{array}$ & & & & & Submissions \\
\hline TOT & & & & & Submissions \\
\hline TOT Description & & & & & Submissions \\
\hline Received Hit & & & & & Submissions \\
\hline $\begin{array}{l}\text { Control ID } \\
\text { (Transmission ID) }\end{array}$ & & & & & $\begin{array}{l}\text { History } \\
\text { Submissions }\end{array}$ \\
\hline TCR Number & & & & & $\begin{array}{l}\text { History } \\
\text { Submissions }\end{array}$ \\
\hline Description & & & & & $\begin{array}{l}\text { History } \\
\text { Submissions }\end{array}$ \\
\hline
\end{tabular}




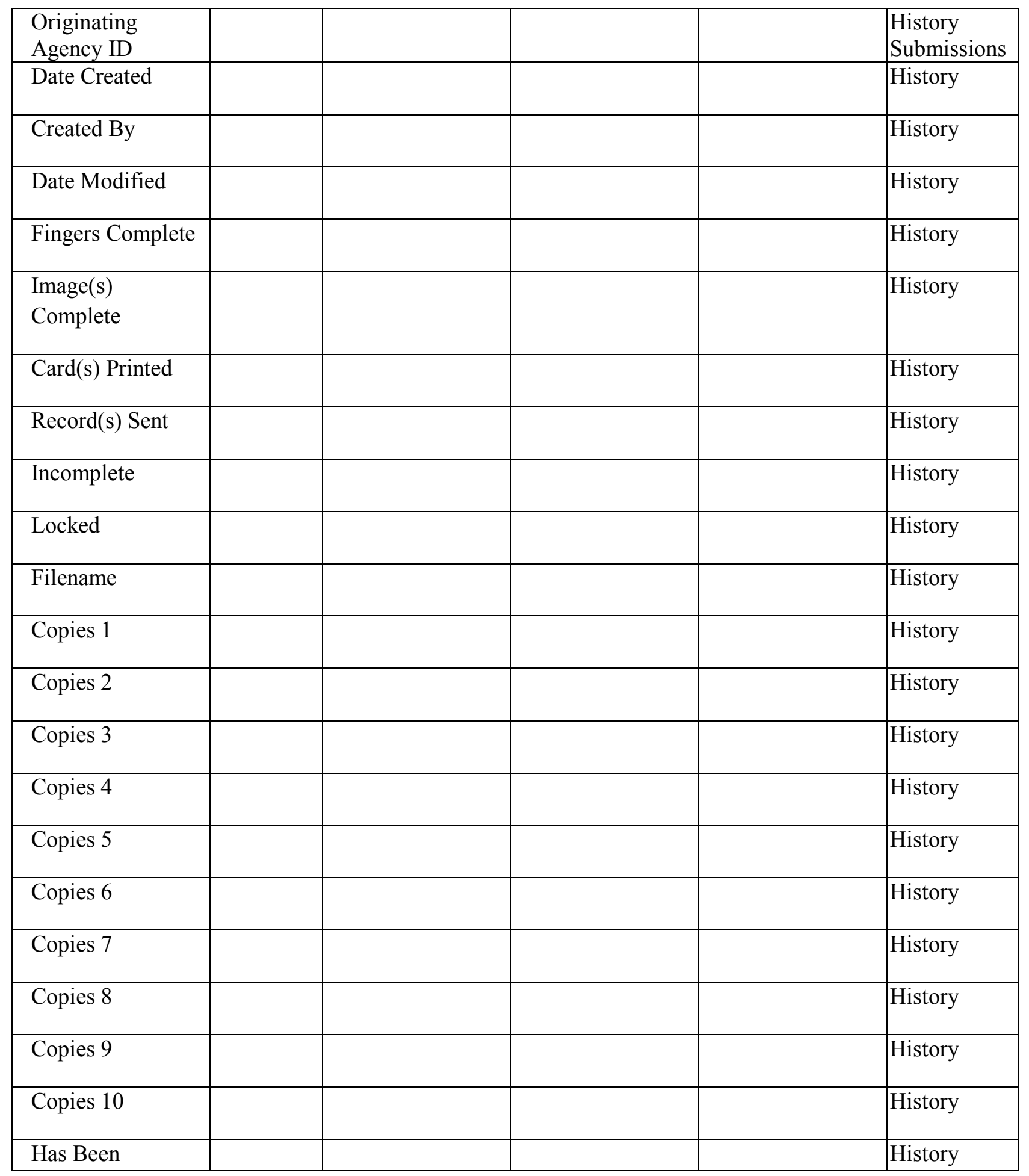




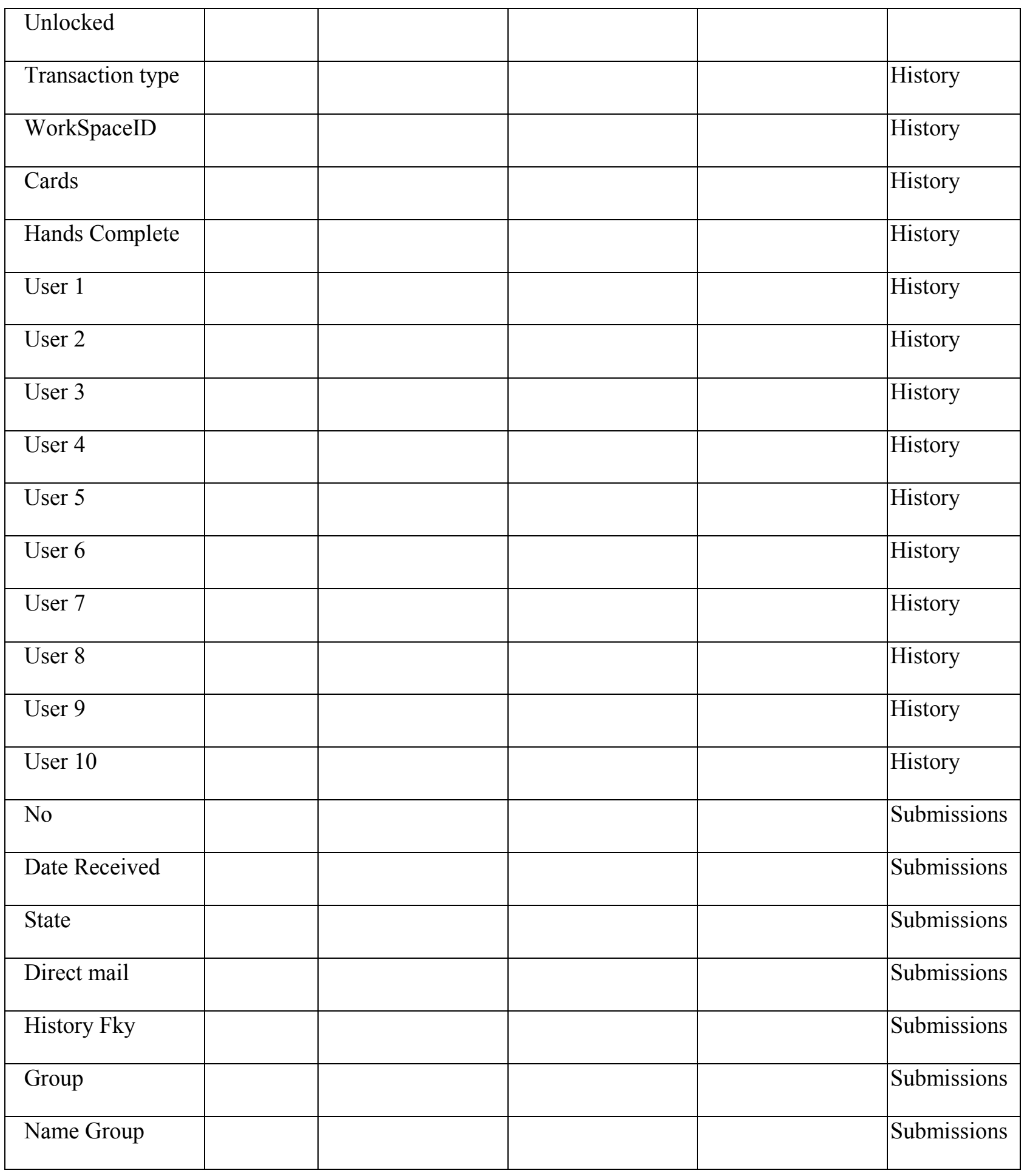




\section{APPENDIX C - SEARCH CRITERIA IN TRANSACTION HISTORY AND SUBMISSIONS}

Appendix $\mathrm{C}$ lists search criteria that can be applied to attributes in the Transaction History and Submissions.

\begin{tabular}{|l|l|l|l|}
\hline \multicolumn{1}{|c|}{ Search Field Name } & \multicolumn{1}{|c|}{ Field Type } & \multicolumn{1}{|c|}{ Field Format } & \multicolumn{2}{c|}{ Values } \\
\hline TCN & Text & Alphanumeric & n/a \\
\hline Last Name & Text & Alphabetic & n/a \\
\hline First Name & Text & Alphabetic & n/a \\
\hline Middle Name & Text & Alphabetic & n/a \\
\hline Date of Birth & Date Range & yyyymmdd & n/a \\
\hline Response Count & Selection & Numerical & 0 \\
& & & 1 \\
& & & $\begin{array}{l}0 \\
3\end{array}$ \\
\hline Status & Selection & Alphabetic & $\begin{array}{l}\text { Saved } \\
\text { Transmitted } \\
\text { Pending } \\
\text { Responded - All } \\
\text { Responded - Hit } \\
\text { Responded - Rejected }\end{array}$ \\
& & & $\begin{array}{l}\text { From: n/a } \\
\text { To: current date }\end{array}$ \\
\hline & & & \\
\hline Date Submitted & Date Range & yyyymmdd & \\
& & & \\
\hline
\end{tabular}




\section{APPENDIX D - FEATURES AVAILABILITY AND ASSOCIATED FUNCTIONAL AREAS}

\begin{tabular}{|c|c|c|}
\hline Functional Area & Conditions & Features Available \\
\hline Personal Data & Editable & $\begin{array}{rrl}\text { - Edit } & & \\
& & \\
& & \text { Cut } \\
& \circ & \text { Copy } \\
& \circ & \text { Paste } \\
\text { - New } & & \\
& & \text { Slaps } \\
& \circ & \text { Query } \\
& \circ & \text { Rolls } \\
\text { - Open } & \\
\text { - Save As } & \\
\text { - Help } & \\
\end{array}$ \\
\hline Personal Data & View Only & $\begin{array}{ll} & \text { Open } \\
\text { - } & \text { Help } \\
\end{array}$ \\
\hline Fingerprints & Editable & $\begin{array}{rll}\text { - } & \text { New } & \\
& \circ & \text { Slaps } \\
& \circ & \text { Query } \\
& \circ & \text { Rolls } \\
\text { - } & \text { Open } & \\
\text { - } & \text { Save As } & \\
\text { - Help } & \\
\end{array}$ \\
\hline Fingerprints & View Only & $\begin{array}{ll}\text { - } & \text { Open } \\
\text { - } & \text { Help } \\
\end{array}$ \\
\hline Photos & Editable & 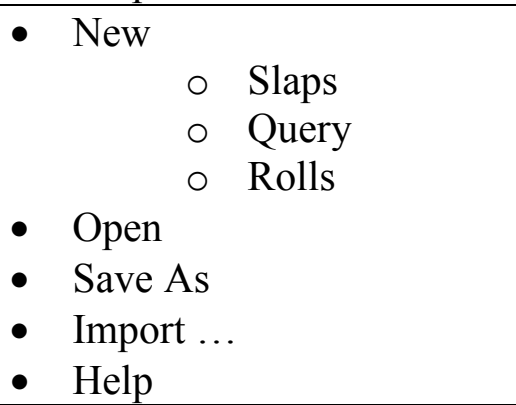 \\
\hline Photos & View Only & $\begin{array}{l}\text { - Open } \\
\text { - Help } \\
\end{array}$ \\
\hline RAP sheets & View Only & $\begin{array}{ll}\text { - } & \text { Copy } \\
\text { - } & \text { Open } \\
\text { - } & \text { Help } \\
\end{array}$ \\
\hline
\end{tabular}




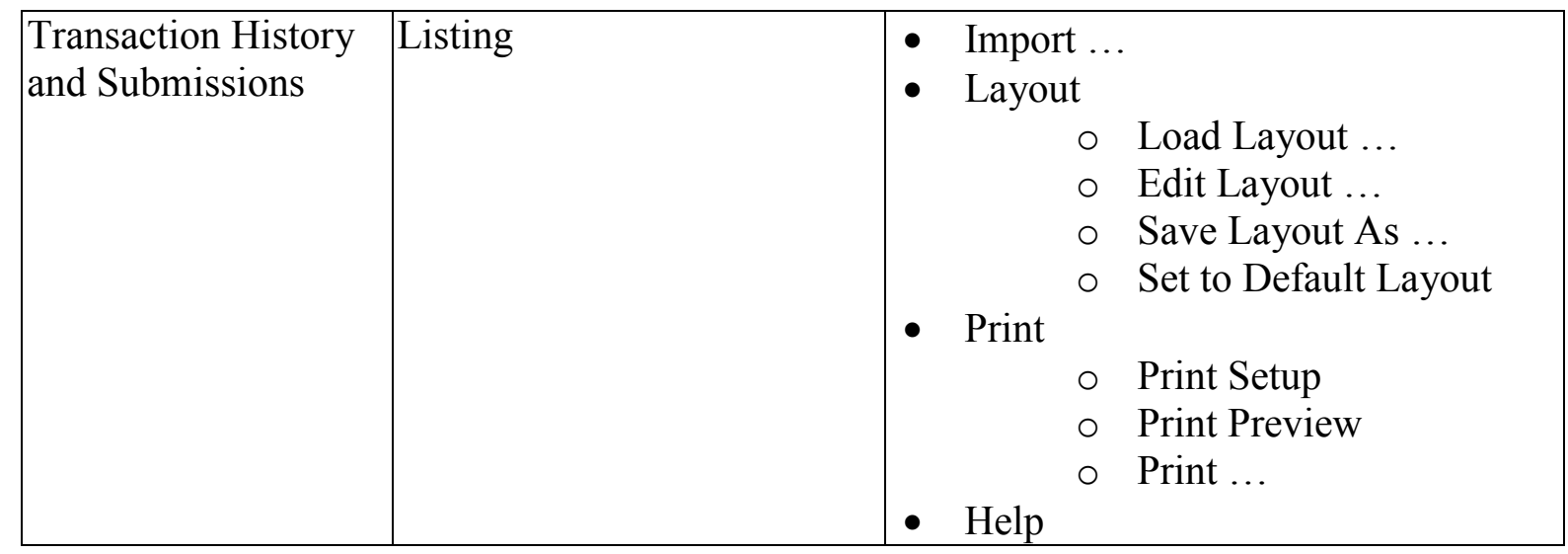

